\title{
From SOVIET DICTATORSHIP TO RUSSIAN DERMO-CRATIA: TOWARD A THEORY OF POLITICAL Justice
}

\author{
BY \\ YANA GOROKHOVSKAIA, B.A. (HONS)
}

\begin{abstract}
A thesis submitted to
the Faculty of Graduate Studies and Research

in partial fulfillment of

the requirements for the degree of
\end{abstract}

Master of Arts

Department of Law

Carleton University

Ottawa, Ontario

August 2009

O2009, Yana Gorokhovskaia 
Library and Archives

Canada

Published Heritage

Branch

395 Wellington Street

Ottawa ON K1A ON4

Canada
Bibliotheque et

Archives Canada

Direction du

Patrimoine de l'édition

395, rue Wellington

Ottawa ON K1A ON4

Canada
Your file Votre référence
ISBN: $978-0-494-60308-6$
Our file Notre référence
ISBN: $978-0-494-60308-6$
NOTICE:

The author has granted a nonexclusive license allowing Library and Archives Canada to reproduce, publish, archive, preserve, conserve, communicate to the public by telecommunication or on the Internet, loan, distribute and sell theses worldwide, for commercial or noncommercial purposes, in microform, paper, electronic and/or any other formats.

The author retains copyright ownership and moral rights in this thesis. Neither the thesis nor substantial extracts from it may be printed or otherwise reproduced without the author's permission.
AVIS:

L'auteur a accordé une licence non exclusive permettant à la Bibliothèque et Archives Canada de reproduire, publier, archiver, sauvegarder, conserver, transmettre au public par télécommunication ou par l'Internet, prêter, distribuer et vendre des thèses partout dans le monde, à des fins commerciales ou autres, sur support microforme, papier, électronique et/ou autres formats.

L'auteur conserve la propriété du droit d'auteur et des droits moraux qui protège cette thèse. $\mathrm{Ni}$ la thèse ni des extraits substantiels de celle-ci ne doivent être imprimés ou autrement reproduits sans son autorisation.
In compliance with the Canadian Privacy Act some supporting forms may have been removed from this thesis.

While these forms may be included in the document page count, their removal does not represent any loss of content from the thesis.
Conformément à la loi canadienne sur la protection de la vie privée, quelques formulaires secondaires ont été enlevés de cette thèse.

Bien que ces formulaires aient inclus dans la pagination, il n'y aura aucun contenu manquant. 


\section{ABSTRACT}

Why did the political transition that followed the collapse of the USSR not result in the establishment of democracy in Russia? I propose a theory of transformative political justice in order to examine the 1991 report of the Commission for the Rehabilitation of Victims of Political Repression and the 1992 trial of the Communist Party of the Soviet Union. I argue that despite beginning as cases of attempted political justice, neither achieved the dual elements of natality: judgement and rebirth. The Commission used the plight of victims of repressions to rehabilitate the Communist Party, and the Constitutional Court failed to condemn the Soviet regime. The lack of critical reflection has allowed for continuity with the authoritarian past to subvert the establishment of democracy. I suggest the potential for political justice still exists and can emerge within the contested areas of public memory and commemoration in Russia. 
Although the difficult process of revision sometimes made my life harder, in the end, it made this project better. And for that, I am thankful.

For their love and support, I thank my wonderful parents.

For her criticism, proving that those of us from the East are plagued by a very dark sense of humour, but mostly for introducing me to the murky world of transitional justice, I thank Professor Christiane Wilke.

For making the last two years about much more than thesis writing, and for everything else, I thank J. 


\section{Contents}

Introduction

Soviet Communism as Kitsch

Chapter One

(Re)defining Political Justice

Chapter Two

Reconciling Natality

Chapter Three

Rehabilitating the Past: The Politburo Commission

Chapter Four

Judging the Past: The Trial of the CPSU

Conclusion

(Re)living the Past 


\section{INTRODUCTION}

\section{SOVIET COMMUNISM AS KITSCH}

“... while the symbol of one mass murder fills us with terror, the symbol of another mass murder makes us laugh.",

Almost twenty years ago Soviet Communism became kitsch. The relics of a dictatorial past, the flags, jackboots, busts of Lenin, books on dialectical materialism, along with innumerable other memorabilia became desirable collectables sold in souvenir stalls to nostalgic Russians and foreign tourists alike. In January of 1992, as people welcomed in the New Year for the first time as citizens of the Russian Federation and not of the USSR, debates at home and abroad raged about what to do with those more prominent markers of the past that could not be sold off. Even The New Yorker joined in on the speculation: "That transcendent model of Soviet kitsch...Surely a better use could be found for the neo-Cubist tomb on the Red Square. A museum? An office building? A Pizza Hut?"'2 The debate surrounding the removal of Lenin's body continued into the mid 1990s through both the Gorbachev and Yeltsin presidencies. A potential burial place was even the subject of a planned referendum vote. Each new proposal, however, met with resistance from political groups in the Russian Chamber of Deputies (the Duma) and none ever garnered much public support. Since then, public demands for the removal one of the most recognizable vestiges of Communism have subsided to a dull murmur. At present, plans for closing the mausoleum have been tentatively set for $2024,{ }^{3}$ keeping the monument open to accommodate the celebration of the $100^{\text {th }}$ anniversary of Lenin's

\footnotetext{
${ }^{1}$ Anne Applebaum. GULAG: A History (New York, London, Toronto, Sydney and Auckland: Doubleday, 2003) at xviii.

${ }^{2}$ David Remnick. "The Trial of the Old Regime" (30 November 1992) The New Yorker, at 104.

${ }^{3}$ Mark McDonald. "Lenin Undergoes Extreme Makeover" (1 March 2004) Associated Press, available online: http://www.artukraine.com/historical/lenin_makeover.htm
} 
death. The fate of this small granite and marble tomb is indicative of the relationship that Russia has with its Soviet legacy. The tendency to first gloss over the past, treating it as kitsch, and then to revive and reclaim parts it, has had very real political and social consequences for the country.

Today, no longer in the hopeful process of transition from dictatorship to democracy, Russia's government is an autocracy filtered through democratic institutions. It is a 'managed democracy' in every sense of the term, and those doing the 'managing' are members of the former regime's elite. Although Russia has all the formal hallmarks of democracy, like constitutionally entrenched separation of powers, opposition political parties, and regular elections, political freedom and democratic development have stagnated. This stagnation can, in large part, be attributed to the formation of a dominant power system in Russia, where the line between state and ruling party is either blurred or erased. ${ }^{4}$ Former President, and current Prime Minister, Vladimir Putin, effectively borrowed parts of both the Communist and nationalist agendas during his two terms in office. He simultaneously brought potential sources of opposition, the parliament, judiciary and media, under executive control while resurrecting the tsarist ideology of Moscow as the 'Third Rome' by expanding Russia's sphere of influence in Eastern Europe. Legal reforms of the 1990s and judicial independence were reversed or curtailed in order to facilitate the concentration of power in the hands of the executive. ${ }^{5}$ The Russian Constitutional Court, established in 1992, was moved from Moscow to St. Petersburg by executive order and its recommendations for reform continue to be

\footnotetext{
${ }^{4}$ Thomas Carothers. "The End of the Transition Paradigm" (2002) Journal of Democracy, Vol. 13 (1): 521. Carothers describes the shift from Yeltsin to Putin as a political 'transfer' rather than a political 'alternation.'

${ }^{5}$ See Michael Rywkin. "Putin's Russia: Neither Friend nor Foe" (2007) American Foreign Policy Interests, Vol. 29 (1): 37-44.
} 
ignored. Criminal courts are now routinely used for partisan persecutions of journalists, scientists, activists, and businessmen with the means and desire to pursue an independent political agenda. ${ }^{6}$ Overall, the legal system has been described as an "inflexible, repressive apparatus meant to defend corporate (government) interests against those of private parties." ${ }^{, 7}$ When Putin speaks of the rule of law in Russia, he is not speaking about the democratic principle which dictates that even the executive branches of government are answerable to the law; instead, he is referring to 'law and order' and the ability of the police to enforce the law to fight corruption. The rollback in democratic reforms has been largely masked by the language of 'stabilization' deemed necessary in order to guide Russia through its transition to a liberal democratic state. In the absence of social consensus on what that transition should look like, however, the government has instituted a "combination of permissible (and tolerable) political authoritarianism and violence...and the maximum possible freedom of economic activity...A democracy 'regulated' from above and the deregulation of the economy.",

Today, as Lenin's Mausoleum continues to occupy a prominent place on the Red Square and the fragments of the Communist past discarded during perestroik ${ }^{9}$ are restored to their original places of honour, one is left to wonder: what happened to Russia's democratic experiment? No single explanation is sufficient to account for the many challenges and obstacles encountered by Russia in the early 1990s. Political

\footnotetext{
${ }^{6}$ Alexander Nikitin and Igor Sutyagin, both research scientists, were prosecuted for treason laws after writing reports critiquing the government's environmental and military programs.

${ }^{7}$ Lev Gudkov. "Russia - A Society in Transition?" (2001) Telos, at 12.

${ }^{8}$ Ibid at 10.

${ }^{9}$ Surrendering to convention, I have chosen to adopt the Latin and not Cyrillic alphabet for words like perestroika and glasnost, as well as the titles of books, newspaper headlines and journal headings. As David Chioni Moore points out, not without irony, this is "a courtesy wholly normal in the culturally subaltern Russian context but one that no Western literature returns." in "Is the Post- in Postcolonial the Post- in Post-Soviet? Toward a Global Postcolonial Critique." (2001) PLMA, Vol. 116 (1) at 121.
} 
instability, a coup attempt, and economic crisis, all affected the course of reform. But something else, something deeper, failed to take root in those years. As sudden as the implosion of the Soviet Union was, the collapse was not accompanied by an attempt at a political 'clean break' with the old regime. There was no reckoning with the past, no line drawn in the sand. Instead, Russia plunged head first into the future. But when the enthusiasm for democratic reform waned and the economy worsened, symbols of the Soviet past, now whitewashed and sanitized, were revived and utilized by the state. Nostalgia met nationalism and the past was made glorious again.

\section{Transitional Justice and Political Transformation}

"How should societies deal with their evil pasts?" 10 This, at heart, is the question that transitional justice literature ${ }^{11}$ tries to answer. In turn, this question opens the door to innumerable other questions about how a state addresses its past and how it links that past to its future. Although the transition in which justice is meant to occur may take many forms, the destination of that transition, or at least the ideal theoretical destination, is firmly fixed in the democratic paradigm. Accordingly, transitional justice scholarship explores those mechanisms of change which take a state from any number of potential regimes into a democracy. ${ }^{12}$ Two of the most common and well-known mechanisms are

\footnotetext{
${ }^{10}$ Ruti G. Teitel. Transitional Justice. (New York: Oxford University Press, 2000) at 3.

${ }^{11}$ For an informative exploration of transitional justice as an analytical concept, and for a general overview of transitional justice mechanisms in Eastern Europe, see Eric A. Posner and Adrian Vermeule "Transitional Justice as Ordinary Justice" (2004) Harvard Law Review, Vol. 117 (3): 761 - 825.

${ }^{12}$ Samuel Huntington was one of the first to speculate on how a democratic government should respond to violations of human rights in the aftermath of an authoritarian regime, specifically in the context of Eastern Europe. His book, The Third Wave: Democratization in the Late Twentieth Century, proposed that democratization can occur in one of four forms: transformation, transplacement, replacement, and intervention. Huntington linked the choice of transitional justice mechanism, either prosecution, amnesty or truth commission, to the kind of transition type a state experienced. While transplacement and transformations coincided with an attitude of forgive and forget, replacement transitions normally resulted in prosecutions. His general conclusion was that Eastern Europe, with the exception of Germany and Romania, had a tendency to forgive and forget.
} 
trials for former political and military elites and truth and reconciliation commissions. ${ }^{13}$

While the trials are mostly criminal prosecutions undertaken by the state, truth commission can be organized by state or non-state actors like NGOs and victim's groups. ${ }^{14}$ Whatever form transitional justice takes, whether punitive or reconciliatory, it seeks to address the past in order to overcome it. Transitional justice, therefore, is a process of reckoning.

But what if this reckoning does not take place? What if a state, or society as a whole, is unwilling to explore past wrongdoing? What if the mechanisms of transitional justice are simple acts of performance that merely acknowledged offences without formal apology, reparations or prosecutions? What if the new state, itself implicated in past crimes, claims the role of victim? What if the moment of political transformation is cut short before making an impact on society?

\footnotetext{
${ }^{13}$ The question of which transitional justice mechanisms, whether truth commissions, blanket amnesties or rigorous prosecutions, can best bring about democratic reform remains a source of speculation. Various legal and political issues involved in formulating laws to grant amnesties or authorize prosecutions complicate the problem further. Many of these laws violate rule of law principles and have been both defended as necessary for, and critiqued as damaging to, the formation of democracy. For context specific and flexible approach to transitional justice mechanisms, see David A. Crocker. "Reckoning with Past Wrongs: A Normative Framework" (1999) Ethics and International Affairs, Vol. 13 (1): 43-64. For a discussion on the obligation of states to pursue prosecutions, and the rule of law limitations on those prosecutions, see Juan E. Mendez. "In Defense of Transitional Justice" in A. James McAdams eds., Transitional Justice and the Rule of Law in New Democracies (Notre Dame and London: University of Notre Dame Press, 1997).

${ }^{14}$ One of the most well-known examples of a truth commission is South Africa's Truth and Reconciliation Commission (TRC) which was set up through the terms of the Promotion of National Unity and Reconciliation Act to hear testimony of victims and perpetrators. The TRC granted amnesty for human rights violations and also provided reparations for victims. Although the goals of the TRC were reconciliatory, most commissions of this nature set the discovery of truth as their primary goal. This tendency has been problematized in a variety of literature. See for example, Erin Daly "Truth Skepticism: An Inquiry into the Value of Truth in Times of Transition" (2008) International Journal of Transitional Justice, Vol. 2: 23-41. Furthermore, the implementation of transitional justice mechanisms does not always mean that a country is in the process of democratic reform. Some countries have had truth commissions that act to strengthen the position of the present government by redefining their role in past crimes. For a discussion of truth commissions in Uzbekistan and Serbia see Brian Grodsky "Producing Truth: The Politics of Investigating Past Human Rights Violations in Post-Communist States" (2007) World Affairs, Vol. 169 (3): 125-133.
} 
Countries in every part of the world have undergone one form or another of political transition following periods of repressive rule. In Eastern Europe, John Borneman has divided the transformations into three types. The first type has abrupt yet relatively smooth regime change accompanied by some restitution for victims but little or no reckoning with past wrongdoing. The second type of transformation is sparked by radical regime change with comprehensive compensation for victims and extensive prosecutions of the old regime. And the third type consists of regime change characterized by more superficial than substantive legal transformation with "minimal recognition of victims and very little or no prosecution of wrongdoing." ${ }^{\prime 5}$ It is within this last category that Borneman places Russia. With little acknowledgment of victims and no wide-ranging political or legal changes, Soviet criminality has impacted neither Russian politics nor Russian memory. Although Communist ideology has now been abandoned, Soviet authoritarianism is alive and well within the Russian government. Likewise, for the general Russian population, Soviet history and past crimes "occupy an insignificant place in the collective memory...if they exist at all." ${ }^{\prime 16}$ There has been no mass rejection of the Soviet system and the process of reform, though begun in the late 1980s and continued through the early 1990s, was eventually abandoned with the results it produced quickly slipping from the public realm. Some have argued that the process of reckoning was unsuccessful in Russia because of its inherent incompatibility with Russian identity: "Russians feel neither guilt nor shame...The very idea of individual, and even less so

\footnotetext{
${ }^{15}$ John Borneman. Settling Accounts: Violence, Justice and Accountability in Eastern Europe. (Princeton: Princeton University Press, 1997) at pp 8-9.

${ }^{16}$ Anatoly M. Khazanov. "Whom to Mourn and Whom to Forget? (Re)constructing Collective Memory in Contemporary Russia" (2008) Totalitarian Movements and Political Religions, Vol. 9 (2-3) at 294.
} 
collective, responsibility remains too vague in Russian culture. ${ }^{, 17}$ But to adopt this attitude is to dismiss a nation of some one hundred and forty million people as incapable of change and undeserving of democracy. What must be more closely examined is not the nature of Russian people, but the moment, scope, shape and consequences of political transformation. I undertake such an examination here.

\section{Natality and Political (Re)birth}

A traditional liberal approach suggests that law and politics should be, and in most cases are, divorced from each other in stable and rule of law abiding democracies. ${ }^{18}$ The transgression of the separation of powers between the branches of government, the use of retroactive legislation, scripted judgments, and stripped down and accelerated legal procedures, are all signs of the very worst aspects of the convergence of law and politics. This approach further suggests that where the law is utilized for political ends, the entire judicial system loses credibility and legitimacy. ${ }^{19}$ It is therefore not surprising that political trials, that dangerous combination of politics and law, are usually examined in the context of totalitarian or authoritative regimes where the legal system serves as little more than a vehicle for the purging of political enemies. ${ }^{20}$ These kinds of trials "have

\footnotetext{
${ }^{17}$ Khazanov,supra note 16 at 301. Khazanov is paraphrasing Catherine Meridale. Night of Stone: Death and Memory in Twentieth Century Russia. (New York: Viking Press, 2000).

${ }^{18}$ The exclusion of discretionary political power form the legal realm is the central concern at the heart of most objections to 'political justice.' The independence of the judiciary from the state, the court's perceived neutrality, is a main tenant of the rule of law. Therefore, the interference of the state in judicial proceedings is often viewed as a corruption of the legal process. "Englishmen are ruled by the law, and by the law alone; a man may be with us punished for a breach of law, but he can be punished for nothing else." $\mathrm{A}$. V. Dicey, Introduction of the Study of the Law of the Constitution (1885) available on-line: $\mathrm{http} / / / \mathrm{www}$.constitution.org/cmt/avd/law_con.htm.

${ }^{19}$ See for example J. B. Grossman's definition of political justice as "a whole range of government efforts to use the legal system to maintain the power of the regime" in "Political Justice in the Democratic State" (1976) Polity, Vol. 8 (3) at 359.

${ }^{20}$ There have been numerous attempts at defining 'political trials.' In general, Otto Kirchheimer's Political Justice: The Use of Legal Procedure for Political Ends (Princeton: Princeton University Press, 1961) is seen as the 'near-definitive' work on the subject. In it, he defines political trials as those in which "the courts
} 
only one agenda, power, and only one issue, expediency, which serves as the substitute for justice. ${ }^{21}$ But are all trials that grapple with the political mere legal charades?

I contend that those trials which are most often referred to as 'political trials,' meaning that they violate some norm of the rule of law, should be more exactly identified as partisan trials. Partisan trials lack any substantive sense of justice. They are the show trials of history, nothing more than "spurious legal proceeding[s]."22 While political trials, separate and distinct from partisan trials, still pose some undeniable risks for democratic development, they also offer an invaluable opportunity for political reevaluation and transformation. In opposition to the opinion that law and politics should be separated, I argue that political trials are fundamentally important to both entrenched and developing democracies. Moreover, the wider category of political justice, encompassing trials and other socio-legal mechanisms, like truth commissions, should be understood as a category of transitional justice. The common goal of political justice and transitional justice is the political redefinition of the public sphere made possible through natality.

Natality is a term first coined by Augustine and explored in the work of Hannah Arendt. "The miracle that saves the world, the realm of human affairs from its normal, 'natural' ruin is ultimately the fact of natality, in which the faculty of action is

eliminate a political foe of the regime according to some prearranged rules" (6). For an example of political trials in totalitarian regimes, those I term 'partisan trials,' see George H. Hodos. Show Trials: Stalinist Purges in Eastern Europe 1948 - 1954 (New York, Westport, London: Praeger, 1987). Hodos explains that the aim of these trials "is to personalize an abstract political enemy, to place it in the dock in flesh and blood and, with the aid of a perverted system of justice, to transform abstract political-ideological differences into easily intelligible common crimes"(xiiii).

${ }^{21}$ Judith Shklar. Legalism. (Cambridge: Harvard University Press, 1964) at 148.

${ }^{22}$ Ron Christenson. Political Trials: Gordian Knots in the Law. $2^{\text {nd }}$ Edition. (New Brunswick and London: Transaction Publishers, 1999) at 10. 
ontologically rooted."23 Put simply, natality is the human capacity for beginning anew, most directly expressed in human birth. Arendt explains that human beings have the ability to initiate completely new courses of action and that history is full of these moments of renewal. She goes on to use the concept of natality to argue that just as human beings have the capacity to bring novel horrors into the world, they also have the ability to sit in judgment, to "comprehend the new and face the unprecedented.",24 Natality, then, can be both a moment of renewal and a moment of judgment. This dual function makes it central to the nature of the political and political justice in general. The opportunity to judge the past, to break with it, and to begin anew, makes political justice indispensable for the formation of democracy. The process of reckoning, which is fundamental to transitional justice, is essentially about natality.

However, if the moment of reckoning is missed and natality is not apprehended, political redefinition and re-evaluation cannot occur. During periods of regime change, political justice without natality loses its transformative potential and the process of transitional justice remains incomplete. I argue that this is what happened in Russia during the collapse of the Soviet Union. Despite opportunities for political justice, the moment of natality was not seized. A break with the past was not made, and the capacity to begin anew was not realized.

\footnotetext{
${ }^{23}$ Hannah Arendt. The Human Condition. (Chicago: University of Chicago Press, 1998) at 247.

${ }^{24}$ Leora Bilsky. Transformative Justice: Israeli Identity on Trial. (Ann Arbour: University of Michigan Press, 2007) at 136.
} 


\section{'Truth' and 'Justice': The Commission and the Court}

In this thesis I examine two opportunities for political justice in Russia: the 1991 report by the Commission for the Rehabilitation of Victims of Political Repression and the 1992 Constitutional Court challenge made by the Communist Party of the Soviet Union (CPSU). Both offered a unique chance for political re-evaluation; both attempted to sit in judgment of history. And although the commission and the court acknowledged the darker parts of the Soviet legacy, in the end, neither broke with that legacy.

On September $28^{\text {th }}, 1987$ a commission was formed by the Politburo of the Central Committee of the Communist Party of the Soviet Union (CC/CPSU) "for the purpose of conducting a thorough examination of the facts and documents connected to the repressive measures used in the late 1930s, 40s, and 50s." ${ }^{25}$ This commission restarted a process of rehabilitation which originally began immediately following Stalin's death in 1953. Initially, the commission's existence was denied by the state and it operated in secret, answerable only to the Politburo. However, after the official disbanding of the Communist Party by Gorbachev in August of 1991, the commission was renamed the Presidential Commission for the Rehabilitation of Victims of Political Repression and reported to the President of the Russian Federation.

The commission's findings published by the Politburo in 1991 are the focus on my analysis and contain both archival material and the commission's efforts at rehabilitating thousands of victims of political repression. This report is important because it represents a key unrealized opportunity for political justice; an opportunity

${ }^{25}$ A. N. Yakovlev eds. Reabilitatsia: Politicheskie protsessy 30-50kh godov. (Moscow: Politzdat, 1991) at 15. The English translation of this text used in the thesis is my own. 
that, I argue, was transformed from an effort to rehabilitate the individual victims of Stalinist terror into an exoneration of the Communist Party as a whole.

Although the Politburo Commission was initiated by the state and made recommendations to the courts for the legal rehabilitation of individuals, it was a political, not legal, instrument. As such, it did not explore the technical legalities of the inner workings of a totalitarian state. It did not address the melding of a political party and the state into a single apparatus where Communist Party will became state policy. The so-called 'verification case' or 'CPSU trial' heard in the Russian Constitutional Court in the fall of 1992 explored exactly these issues and presented another opportunity for a political justice.

Mikhail Gorbachev, the USSR's last General Secretary, began a modest program of reforms in the late 1980s, which was dubbed perestroika. Far from intending to break up the Soviet Union, Gorbachev wanted to strengthen the Soviet system by allowing minor economic and political restructuring that would stabilize the country. These reforms, however, prompted a small cohort of hard-line communist deputies to attempt to seize power in August of 1991. The three day stand-off that followed the coup attempt by the State Committee for the State of Emergency (GKChP) led to wide-spread popular demonstrations in support of Gorbachev and culminated in the official disbanding of the Communist Party. Presidential decrees freezing Party property and calling the Party 'unconstitutional' quickly followed the disbanding. For a time "it looked as if Gorbachev's tentative reforms had given way to real liberal revolution. ${ }^{26}$ But a small group of CPSU supporters was not ready to let the Communist Party be quietly relegated

\footnotetext{
${ }^{26}$ Kathleen. E. Smith. Mythmaking in the New Russia: Politics and Memory during the Yeltsin Era. (Ithaca and London: Comell University Press, 2002) at 1.
} 
to the past. Transitional justice literature is full of trials of former elites, but these trials are seldom initiated by those elites. In Russia, however, this is precisely what happened.

A group of deputies from the Supreme Soviet challenged the validity of the presidential decrees and chose the newly created Russian Constitutional Court as the venue for their appeal. In response, an ad hoc group of parliamentarians filed a petition alleging that the CPSU had been involved in the coup attempt and asked the court to evaluate the Party's constitutionality. In September of 1992, the Constitutional Court combined the petitions of both parties into a single case.

In the end, the court proceedings ended up focussing on the role of the Communist Party throughout Soviet history rather than its political future. Both sides in the trial tried to argue their version of history, properly redacted for maximum effect. And while in its judgment, the court, just like the Politburo Commission, acknowledged the many atrocities committed by Soviet authorities, it did not condemn the Communist Party or the Soviet system as a whole. The case did not draw a line between the old and the new regimes. Rather, by emphasizing stability and the voluntary nature of reform, it highlighted the continuity between the two periods of time. I argue that despite beginning as an opportunity for political justice, this case was turned into yet another way for the Party to rehabilitate itself.

\section{Forgetting and Remembering}

When political redefinition is realized, and natality apprehended, the effects reach deep within a society. Therefore, in order to examine the broader consequences of a stunted transition, I conclude this thesis by discussing the current state of memory and commemoration in Russia. Overall, no substantial efforts beyond the work of a few 
human rights organizations have been made to deal with the history of repressions during the Soviet period. There have been no lustrations, or criminal prosecutions, and no turnover of the administration. Most members of the government and judiciary were actively involved within the old Soviet system, and some have gone as far as to use this connection when campaigning for political office. ${ }^{27}$ Laws created to deal with perpetrators are vague and have never been tested in a criminal court. ${ }^{28}$

Although the legacy of repression in Russia remains un-addressed, the past is neither forgotten nor ignored. On the contrary, a specific kind of remembering, a politically useful nostalgia, is alive and well. Over the last decade, an effort to streamline public memory in order to create a hegemonic national narrative has been undertaken by the government. After an initial cleansing and removal of Soviet symbols, the streets of Russian cities and towns are being replenished with tangible reminders of the Soviet legacy. ${ }^{29}$ Independent sources of countermemory, like the NGO Memorial, find themselves the targets of criminal investigations, while special measures, including a newly announced state commission for the protection of Russian history, are implemented to protect an officially sanctioned positive version of Soviet history. This

\footnotetext{
${ }^{27}$ Vladimir Putin famously demonstrated martial arts moves he learned while working as an agent for the KGB in East Germany while campaigning for the president in 2000.

${ }^{28}$ Article 18 of the Law for the Rehabilitation of the Victims of Political Repression, which provides for criminal sanctions against those found to be responsible for the extra-legal administration of Soviet justice, passed by the State Duma in 1992, has never been used to bring anyone to trial.

${ }^{29}$ The debate surrounding the restoration of 'Iron' Feliks Dzerzhinskii to his former spot in Lubyanka Square in Moscow is just one example of the reclaiming of Soviet symbols. While this particular statue has not been restored, due in part to the opposition of the Moscow mayor, other statutes, including those of Lenin and Stalin, have been returned to their former places of honour. The progression of restoration can be traced through the interesting history of Moscow's Park of the Arts in which many of these statues were first dumped, promptly being vandalized, only to be put upright and restored by the state. Many of the statues now carry the inscription: 'It has historical and artistic value. The monument is in the memorializing style of political-ideological designs of the Soviet period. Protected by the state.' There is not a little irony in the last line of the inscription. See, Benjamin Forest et al. "Post-totalitarian national identity: public memory in Germany and Russia" (2004) Social \& Cultural Geography, Vol. 5 (3): 357 - 380.
} 
official reclamation of history is part of a gradual process of re-legitimization of the Soviet regime underway in Russia today and has been made possible by the failure to apprehend the dual elements of natality: judgement and rebirth. Mechanisms of authoritarianism that formed the foundation of the Soviet system were never fully discredited during Russia's transition from the Soviet Union. Instead, they were allowed to remain embedded within the political system and are now being resurrected and normalized by the state.

And yet, in contrast to the shrinking public sphere in Russia, the state's hold and control over the indefinite space of public memory is tenuous and uncertain. As such, I argue that the battle over memory represents another opportunity for the realization of natality and the cementing of a message of 'never again.' A judgment of the Soviet past would mark certain state actions as unacceptable, thereby drawing a clear and much needed boundary around the legitimate use of state power. While the attempt to control efforts at remembrance and rehabilitate the Soviet past is a way for the state to reinforce the legitimacy of authoritarianism, it also holds potential for political justice culminating in the rejection of the Soviet legacy. Consequently, I argue that the contested terrain of memory should be understood as the next avenue of political justice in Russia.

\section{Chapter Overview}

In chapter one I address the problem of defining political justice. I suggest that typologies of political justice have obscured the two central conceptual problems: what political justice is and what it can achieve. Accordingly, I begin by separating political justice from partisan justice on the basis of the presence of risk. I supplement and expand on Otto Kirchheimer's definition of political justice by utilizing Hannah Arendt's 
understanding of politics as space where many competing concerns, including power, coexist. Based on this reformulation of politics, I argue that political justice transcends the court room and can be found in other socio-legal instruments capable of facilitating political transformation, like a truth commission or constitutional challenge. I conclude the chapter by looking at examples of political transformation achieved through political justice.

In chapter two I connect the theory and case studies included in this thesis by asking: if political justice holds potential for the redefinition of a polity, why did it not facilitate political transformation in Russia? I base my discussion in Arendt's conceptualization of the 'gap' between past and future, within which an individual can experience the dual components of natality: judgment, which takes place through an examination of the past, and rebirth, which is future oriented and initiates action. I argue that in August of 1991, during the coup attempt against Gorbachev, such a 'gap' emerged in Russia. Within it, citizens acted through word and deed, judging the Soviet past and creating a new beginning, thereby fulfilling the twofold elements of natality. This moment of apprehended natality did not entrench political transformation because action takes place within a plurality of community and is therefore inherently unpredictable. Thus, I argue, political justice is an attempt at, not guarantee of, political transformation. In chapter three I examine the first case study: the Commission for the Rehabilitation of Victims of Political Repression. I ask: how and why did the process of rehabilitation begin? Which individuals were included and what purpose did the recognition of their victimhood serve? How was Soviet history represented? In the end, I argue that this process actually rehabilitated the Communist Party and the Soviet legacy by shifting culpability to particular individuals and absolving the Soviet system as a 
whole. The Commission failed to judge the Soviet past sufficiently and therefore did not fulfill the conditions of natality.

In chapter four I examine the second case of attempted political justice: the 1992 Constitutional Court challenge brought against the President of the Russian Federation by Communist Party representatives. I begin by discussing the circumstances that surrounded the challenge, including the history of perestroika and the August 1991 coup. Within the trial I focus specifically on the way both the CPSU representatives and their opponents constructed, redacted, and presented Soviet history. I suggest that while the Communist Party defenders were able to weave a cohesive and convincing grand narrative, the democrats fought an ineffective war of details. In the end, I argue, the decision of the court to only find the upper echelons of the Communist Party unconstitutional resulted in a failure to judge the Soviet system completely and meet the dual elements of natality. Instead, the ruling vindicated the Communist Party's version of history, and allowed for its continued political relevance.

In the conclusion I bring the discussion of political justice into the present. I suggest that an incomplete break with the past, caused by the failure to apprehend the moment of natality, has stunted democratic development. Today, the government's effort at controlling sources of memory and sites of commemoration is both a symptom of the incomplete transition from authoritarianisms and an opportunity for political justice. I argue that a judgement of the Soviet past which will discredit authoritarianism enough to make it politically illegitimate is still possible. I complete this work by proposing that the contestation of memory is the next opportunity for political justice in Russia. 


\section{Chapter ONE}

\section{(Re)defining Political Justice}

"...the linkage of politics and justice is characterized by both promise and blasphemy. ",

Political justice, its identification, definition, mechanisms, motives and consequences has been debated, some argue, since Socrates was made to drink hemlock twenty four hundred years ago. ${ }^{2}$ Despite the competing definitions and volumes of work produced on the subject, the concept remains an aporia, a theoretical impasse. ${ }^{3}$ As such, questions on this matter not only continue to go unanswered, but also persistently generate opposing arguments. What is political justice? Is it law or politics, or the corruption of both? Is the term political justice always pejorative, or can it simply be descriptive? Are there degrees of political justice? Can political justice take place in democratic regimes, or is it just one more tool of political oppression used by authoritarian governments? Can the motives of the actors involved in political justice constitute its political nature, or are they irrelevant?

In this chapter, I provide neither an anthology of political justice definitions, nor a retrospective of the most notorious political trials. These approaches have already been undertaken extensively. ${ }^{4}$ Instead, I make two separate but related arguments: I argue, first, that political justice is distinct from the more oft-discussed partisan justice; and second, that political justice is important because it facilitates the transformation of a

${ }^{1}$ Otto Kirchheimer. Political Justice: The Use of Legal Procedure for Political Ends (Princeton: Princeton University Press, 1961) at vii.

${ }^{2}$ Ron Christenson includes cases against everyone from Socrates to Jesus to the Ceasescu couple in his book Political Trials in History: From Antiquity to the Present (New Brunswick and London: Transaction Publishers, 1991).

${ }^{3}$ Aporia originates from ancient Greek and means doubt or perplexity. The term has been adopted by Jacques Derrida and in his work generally refers to the 'blind spot' of a metaphysical argument.

${ }^{4}$ See for example, R. Christenson, B. Wright, M. Greenwood, T. Becker, K. McNaught, G. Hodos, C. Abel and F. Marsh. 
polity. The retooled understanding of the political as a space, which allows for broader application of the concept, is more consistent with its ability to provide the opportunity for political redefinition and re-evaluation through a concentrated examination of collective memory and identity. I argue that this capacity for re-evaluation and redefinition constitutes the "transformative potential' ' of political justice.

Because the definitions of political justice are ubiquitous and the nomenclature surrounding it is confused, the problems of definition and characterization are related. The uncertainty of terms may be attributed to the long history of political justice, or the innumerable attempts made at moulding the concept to fit a particular conceptual paradigm. Whatever the particular cause, in order to address both problems simultaneously, I have chosen to employ the term political justice: political, not partisan; justice, not trials. With this terminology, I provide a clearer vocabulary for the subject matter and re-examine the ascribed and real meaning of 'the political.' I build the concept of political justice in opposition to the one proposed by Otto Kirchheimer, and offer an understanding of politics that is not limited to the concerns of power. I argue that, reconceived of in this way, political justice has much wider application than was ever envisioned by Kirchheimer. I conclude this chapter by discussing examples of political justice that have successfully facilitated political redefinition. I do this here because, while the exact mechanism through which political justice is capable of facilitating political transformation, namely natality, is the subject of the next chapter, it is

\footnotetext{
${ }^{5}$ The term 'transformative potential' is inspired by the title of Leora Bilsky's work on Israeli political trials. One of the key arguments in her book centers on problematic tendency of pigeonholing important trials into 'legal,' 'political,' or 'historical' categories, a practice which masks the fact that these "transformative trials [ ] fulfill an essential function in a democratic society by exposing the hegemonic narrative of identity to critical consideration." Transformative Justice: Israeli Identity on Trial. (Ann Arbor: The University of Michigan Press, 2007) at 7.
} 
nevertheless necessary to demonstrate the positive potential of the concept in order to rescue it from the shadow of partisan trials. I begin, however, at the traditional, though often misleading, point of partition between political justice and the so-called nonpolitical 'rest' of the legal system.

\section{Political, not Partisan}

Those interested in the question 'What is a political trial?' have traditionally begun their discussion by either constructing or adopting a typology of political justice. ${ }^{6}$ This process is essentially a series of comparisons through which cases of political justice are first identified and then separated into categories. Typologies present certain benefits for the purposes of clarity and organization. But each categorization, each separation, can also be a point of contention. In fact, the most basic of arguments within the discourse of political justice originates in the very first, and perhaps most necessary, of distinctions. If the judiciary functions as a mechanism of the state, then are all trials political? However, whether the answer to this question is yes or no makes essentially no difference. The inquiry sets up a misleading dichotomy between the law as 'neutral,' meaning free of politics, on the one hand, and 'biased,' meaning riddled with political motivation, on the other. I will return to the implications of framing politics as a contaminant of the legal system below, for now it is enough to say that for most scholars both of these choices are unsatisfactory because they are quixotic and undercut further analysis. ${ }^{7}$ The basic premise

\footnotetext{
${ }^{6}$ Various authors on the subject have undertaken the onerous task of categorizing instances of political justice. Perhaps the most original, and most roundly criticised, approach is contained in Theodore Becker's Political Trials (Indianapolis and New York: The Bobbs-Merril Company, 1971). Becker separates the trials into political trials, 'political' trials, political 'trials,' and 'political trials.' The quotation marks are meant to highlight the problematic or dangerous aspects of each category (pp. xii-xiii).

${ }^{7}$ It should be noted that in the early English common law tradition, trials could be identified as political based on the involvement of the Crown prosecution. At that time, a majority of prosecutions were undertaken privately, by the victim or victim's family. Therefore, those trials in which the Crown chose to
} 
of political justice literature therefore, is that some trials are political and others are not. Given this, the central question becomes: 'Which trials are political?'

One of the simplest ways of addressing the above question is to limit the applicability of the term political justice to the prosecution of 'classic' political offences like treason, sedition or espionage. ${ }^{8}$ The appeal of this logic lies in the fact that the crimes charged are committed directly against the state and are clearly 'political offences.' These crimes "threatened the safety of the state [and constituted] legal responses to officially apprehended security threats." ${ }^{9}$ Defining political trials in this way allows for a measure of continuity in analysis because, in Canada at least, the Criminal Code adopted almost wholly unchanged the language prohibiting these crimes from the 1351 British statute. ${ }^{10}$ Over centuries, the framework of the crime has remained largely static and provides a comprehensive basis for investigation of political offenders. However, despite the many useful options it offers for analysis and comparison, this limited definition is problematic because it makes no attempt to "embrace the vast realm of interactions between law and politics." "It therefore cannot accurately encompass the phenomenon of political justice, especially in the modern state.

Clearly then, it is unsatisfactory to claim that either all trials are political because the "courts are government agencies and judges are part of the "system,","12 or that only trials for legislatively designated 'political crimes' are political. Consequently, one must

participate in could be rightly labelled political justice since they were the product of a political choice. These trials, however, are usually referred to as 'state trials.'

${ }^{8}$ For an explanation of the origins of treason and sedition legislation in the Anglo-American tradition, see Elizabeth Grace and Colin Leys. "The Concept of Subversion and Its Implications" in C.E.S. Franks eds., Dissent and the State. (Toronto: Oxford University Press, 1989).

${ }^{9}$ Murray Greenwood and Barry Wright eds., Canadian State Trials, Volume 1: Law, Politics, and Security Measures, 1608 - 1837. (Toronto, Buffalo and London: University of Toronto Press, 1996) at 10.

${ }^{10}$ See 'the process of reception,' in Grace and Leys, supra note 8 at 64.

${ }^{11}$ Greenwood and Wright, supra note 9 at 10.

${ }^{12}$ Becker supra note 6 at xi. 
alter the central question to 'How is this trial political?' It is here, in the grey area of subjective judgment, that the topic becomes most contentious. One popular way of evaluating trials to determine their 'political nature' has been to examine the motivations of the prosecution in relation to the personal history of the defendant. In these cases, the actual court procedure can be unbiased and the crimes charged seemingly non-political. But if the defendant has a history of actively, or, in some cases, passively opposing the state or state policies, and they cannot be convicted of a traditionally conceived 'political offence,' other charges may be used to prosecute them. ${ }^{13}$ While more adequately grappling with the many ways law and politics interact, this kind of analysis is problematic because it assumes from the onset that political trials are essentially about power. It works on the hypothesis that within them, a political opponent to the state is isolated and punished using the legal system, with the end goal being the maintenance and legitimization of state power. Otto Kirchheimer's classic definition has longestablished this picture of political justice.

In the Preface to his 1961 work, Political Justice: The Use of Legal Procedure for Political Ends, Kirchheimer begins by introducing the American reader to the concept of political justice. He explains that the term, traditionally understood as the "search for an ideal order in which all members will communicate and interact with the body politic to assure its highest perfection," is now applied to the "most dubious segments of the administration of justice, that segment which uses the devices of justice to bolster or

\footnotetext{
${ }^{13}$ The case of J.S. Woodsworth and F. J. Dixon, two newspaper publishers, charged with seditious libel for continuing to report favourably on the Winnipeg General Strike of 1919 , is one example. Some have argued that the Canadian government overreacted to the strike which followed in the wake of the Russian Revolution and overzealously prosecuted individuals on petty charges like common nuisance, libel, and conspiracy. For a full discussion see Kenneth McNaught. "Political Trials and the Canadian Political Tradition" (1974) University of Toronto Law Journal, Vol. 24: 149 - 169.
} 
create new power positions." ${ }^{\text {14 }}$ Kirchheimer's definition, from which Judith Shklar, Ron Christenson and Theodore Becker, along with others, take their lead, is a fairly straightforward if limited one: political trials are those in which "the courts eliminate a political foe of the regime according to some prearranged rules." 15 The political foe may be a real or imagined threat, the prearranged rules may be fair or unfair, and the courts may be impartial or biased. These distinctions make up the categorization of political justice which Kirchheimer undertakes in the rest of his work. ${ }^{16}$ The point of political justice, however, remains unchanged throughout: "The aim of political justice is to enlarge the area of political action by enlisting the services of the courts on behalf of political goals...Those instrumental to such submission seek to strengthen their own position and weaken that of their political foes."

Because Kirchheimer views political action as inherently concerned with "changing or confirming power relations," 18 he frames it in accordance with the theme of power. Therefore, for him, all political trials are about competing power interests. Accordingly, as the concept political justice has evolved, from the simple treason trial to the more complex political trial as a tool of policy dissemination, the struggle for power has become multifaceted. The contest is no longer limited to deciding who will be in charge; it has expanded to who will control public opinion. "It [political justice] aims not only at eliminating political adversaries from the political arena. The psychological effect

\footnotetext{
${ }^{14}$ Kirchheimer, supra note 1 at viii.

${ }^{15} \mathrm{Ibid}$ at 6.

${ }^{16}$ Kirchheimer divides political trials into three categories " $\mathrm{A}$ ) The trial involving a common crime committed for political purposes and conducted with a view to the political benefits which might ultimately accrue from successful prosecution; B) The classic political trial: a regime's attempt to incriminate its foe's public behaviour with a view to evicting him from the political scene; C) The derivative political trial, where the weapons of defamation, perjury and contempt are manipulated in an effort to bring disrepute on a political foe" at 46.

${ }^{17}$ Kirchheimer, ibid at 419.

${ }^{18}$ Otto Kirchheimer. "Politics and Justice" (1955) Social Research, Vol. 22 (1) at 377.
} 
of the proceedings on the population is also a large consideration." ${ }^{, 19}$ But despite the other faculties that political justice has taken on over time, at heart, power remains the central concern of political justice for Kirchheimer.

Despite adopting this theme of power, Kirchheimer and others, do not deny that political justice occurs with regularity in democratic and constitutional regimes. For them, political justice is about power, not force. It is a contest, or a battle, between power positions. It is not the widespread, unhindered and unrelenting suppression of opposition. This force-based understanding of political justice should be reserved for totalitarian regimes that ruthlessly uphold and maintain their dominance over a population through the use of extensive prosecution, often under the guise of protecting and defending a political ideology. This phenomenon is more accurately labelled 'partisan justice' or 'show trials'; it is wholly and completely distinct from political justice. However, in the last one hundred years, these terms, through various accidents of history and the not so accidental use of propaganda, have become conceptually intertwined and linguistically interchangeable. This presents a real challenge for any contemporary discussion of political justice which is often pre-emptively marred by the legacy of partisan justice. I examine partisan justice more closely below in order to separate it from political justice. I do this through a review of definitions combined with an exploration of Kirchheimer's 'risk distinction.' I then return to the above discussion of power and begin to point away from Kirchheimer's understanding of politics. As a final step in separating political justice from partisan justice and the pursuits of power, I conclude this section by

${ }^{19}$ Kirchheimer, "Political Justice," supra note 18 at 381. 
exploring a framework of the political as a 'space,' as opposed to a means or ends of power.

\section{Understanding Partisan Justice}

In everyday conversations, media coverage, reports compiled by NGOs, and even scholarly literature, it has become commonplace to refer to unfairly detained or imprisoned individuals as 'political prisoners.' Christenson points out that the term 'political justice' evokes images of Joan of Arc, Thomas More and Galileo. These people "have come to us in the judgment of history as heroes unjustly prosecuted."20 They perished under regimes made less comprehensible to us by virtue of the passage of time and can therefore be at least partially weeded out from contemporary discussions. The instances of so-called political justice during the Cold War era, however, are both historically recent and culturally relevant and have cemented the concept's negative connotations. Whether this kind of political justice took place in the West or the East, whether it was the 1951 trial of the Rosenberg couple for espionage or the 1965 trial of Andrei Sinyavsky and Yuli Daniel for ideological subversion, the impression of justice sacrificed in the name of expedience persists. The phenomenon to which the trials of the Cold War era, and the more recent incarnations of the law being used as a tool of suppression, should be rightly understood and labelled as partisan justice.

Partisan comes from the Latin word pars meaning side and it has retained this meaning in modern usage, now denoting something biased or one-sided. Although partisan justice has been in the past most closely associated with periods of state

\footnotetext{
${ }^{20}$ Ron Christenson "A Political Theory of Political Trials" (1983) Journal of Criminal Law and Criminology, Vol. 74 (2) at 549.
} 
emergency, constitutional crisis or revolution, totalitarian regimes of the twentieth century have given the concept a certain permanence, not limiting its employment as the option of last resort but rather instituting it as a normal part of the administration of justice. Innocent victims, extremist regimes and a general sense of illegality all characterize partisan justice. But wherever and whenever partisan justice occurs, it can be safely argued that it has two main identifiable characterises: expediency and certainty. These types of trials are convenient for the state because they publically and officially reprimand or destroy opposition within a setting where the outcome is predetermined long before the process begins. The shroud of a supposedly 'independent' judiciary acts to legitimate the outcome and make the removal of a political foe seem less like the naked exercise of power. In addition to the goal of eliminating a political foe, Shklar has proposed that partisan trials also serve the purposes of propaganda and re-education. ${ }^{21}$ Whether these are Peoples' Courts of Nazi Germany or the innumerable prosecutions in the Soviet Union, where "individual guilt [was] replaced by class expediency,",22 the outcome was fixed in advance and in many cases the verdict was written before the case was heard. The unlucky defendant here had but two choices. He could participate in the farce, and either proclaim his innocence or his agreement with the charges, or he could steadfastly refuse to participate thereby undermining the trial's 'educational' value. ${ }^{23}$ In either case, his fate was sealed almost at the moment of arrest or detention.

\footnotetext{
${ }^{21}$ Judith Shklar. Legalism. (Cambridge: Harvard University Press, 1964) at 148.

${ }^{22}$ Alexander Solzhenitsyn quoted in Christenson, supra note 20 at 552.

${ }^{23}$ Somewhat strangely, Kirchheimer proposes that participation in the trial, however unfair the proceedings, is actually favourable for the defendant. In what can only be described as a romanticized view of partisan justice, Kirchheimer believes that participation in these trials saves the defendant from becoming just a "statistical incident." Political Justice, supra note 1 at 97.
} 
There are those who argue that partisan justice is not limited to unconstitutional states. Based on the categories of expediency and certainty, some have pointed to partisan trials within the United States, Canada or Britain where the defendant was prosecuted using special courts or tribunals and where the end result could be predicted well in advance. Yet can these trials really be called partisan? Shklar has proposed that we separate partisan from political justice based on the kind of politics it advances:

"To be sure, within a stable constitutional order political trials may be a disgrace, a reversion to the politics of repression, but it is not the political trial itself but the situation in which it takes place and the ends that it serves which matter. It is the quality of the politics pursued in them that distinguished one political trial from another [emphasis added]."24

While this is perhaps an adequate moral distinction, one which takes its lead from Shklar's formulation of legalism, it can serve no objective purpose. How are we to judge the quality or worthiness of one political agenda over another? We may all safely agree that the repression of dissenting political opinions through the severe limitation of free speech is an unconscionable use of the legal system, yet we may all just as equally disagree about the scope free speech must be given. Each prosecution, therefore, would evoke an avalanche of varying arguments. Not only would we be unable to identify partisan trials, this formulation would take us back to the original discounted proposition that all trials are political. But although a definition based on a judgment of the kind of politics that a trial promotes is inadequate, it does point the way to a more useful tool of distinguishing partisan trials from political trials. After all, we can judge the constitutional quality of a regime by its willingness to act within the rule of law, even when seeking to eliminate political enemies.

\footnotetext{
${ }^{24}$ Shklar, supra note 21 at 145 .
} 
The difference between partisan trials and political trials is not simply "a matter of frequency or severity. It also lies in the fact that it is impossible for a democratic government to calculate in advance the outcome of a criminal prosecution [emphasis added]. ${ }^{25}$ In a proper political trial the defendant cannot be prevented from putting on a defence and the court cannot be manipulated in such a way as to guarantee a favourable verdict. Procedural safeguards, like the rules of evidence, general restrictions of 'secret proceedings,' safeguards against retroactive legislation, all of which form the basis of the rule of law, limit the powers of the regime in a court setting.

Therefore, for the constitutional state, the attempt to eliminate a political enemy through a political trial always carries the element of risk. These safeguards ensure that a trial remains political and does not slip into the realm of partisan justice. "Where tradition remains powerful enough to preserve a minimum of procedural guarantees, the political trial today remains a contest, rather than a unilateral reaffirmation of unassailable power positions. $" 26$ This is of course not to say that political trials are always fair. The defendant faces a much stronger opponent. An opponent that has at his disposal the entire repressive machinery of the state beginning with the police and ending with the judiciary, which, one can argue, have been traditionally reticent to rule against the status quo. Nevertheless, the defendant in a political trial stands a chance of winning and thereby legitimating their cause and their actions.

The element of risk, as I suggest above, developed alongside the rule of law and was described, in the context of nineteenth century political trials, as a 'wall' erected in order to provide protection to political dissenters against arbitrary or unhindered uses of

\footnotetext{
${ }^{25}$ Kirchheimer, "Politics and Justice," supra note 18 at 379.

${ }^{26}$ Kirchheimer, Political Justice, supra note 1 at 50.
} 
state power. The high measure of proof needed to successfully prosecute individuals for treason brought the distinction between "differences of opinion about the pursuit of national policies and making common cause with the external foe" ${ }^{, 27}$ into sharp relief. But, as Kirchheimer points out, revolutions and the general rise of extremist regimes after WWI, slowly dismantled this wall, eventually breaking the barrier and blurring the distinction between political opposition and treason. Yet in a political, unlike a partisan, trial pieces of this wall made up of the rule of law remain and are embodied in the presence of risk. Political trials are neither expedient nor certain; the regime can never be assured of the verdict or even whether the desired guilty verdict will be convincing or persuasive to the public. Partisan trials carry no such risk. They are mere shows. This is a fundamental difference, and the reason why trials in totalitarian or unconstitutional regimes can be rightly called partisan. It is important to note, however, that as much as political trials carry risks for the state that chooses to use them, they also carry what Kirchheimer described as 'glittering rewards,' something that partisan trials can never offer. This has to do with the nature and significance of a judicial system for the state and I will return to this discussion in the next section.

If we distinguish between partisan and political trials, does Kirchheimer's definition of political trials as the elimination of political foes through judicial means hold? I argue that it does not. Shklar's assertion that "there is politics and politics,"28 is perplexing and in many ways adds more questions than it can ever resolve. Judging the quality of politics in political trials is, as I have already discussed, a somewhat futile effort. But acknowledging the difference between the politics of power of Kirchheimer,

\footnotetext{
${ }^{27}$ Kirchheimer, Political Justice, supra note 1 at 62 .

${ }^{28}$ Shklar, supra note 21 at 143.
} 
and the politics of space of Arendt, can help to broaden the discussion about the role of political justice within society. And having already loosened the hold of the partisan associations on political justice, I conclude this section by asserting that political justice should be understood as providing a space for political debate, rather than a means of affirming or defending political power.

\section{Space, not Power}

Kirchheimer understands political justice as a device used to 'bolster and create' power positions. It is from this definition of politics founded on power that the political is framed as a pollutant of the law. Based on the assumption that "political interests contaminate the legal means employed to achieve legitimate social expectations, ${ }^{29}$ political justice has gained a pejorative connotation. Perceiving politics as a means through which to contest power or, alternatively, to view power as the ultimate end of politics, is to conceive of the political in the narrowest sense. This narrow understanding is responsible for Kirchheimer's definition of political justice, specifically, his focus on the 'political foe.' But what if the political was about more than the defence of one's own power and the attempt to destroy competitors? What if we moved beyond the understanding of politics as the pursuit, defence, goal, or ultimate aim of power? What if the political was a space within which power was not the sole but one of many competing concerns?

In The Promise of Politics, Hannah Arendt sets out a theory of politics which offers an alternate approach to understanding political justice. In this work, Arendt is

\footnotetext{
${ }^{29}$ Aurora Voiculescu. Human Rights and Political Justice in Post-Communist Eastern Europe: Prosecuting History. Studies in Social and Political Theory, Vol. 24. (Lewiston, Queenston and Lampeter: The Edwin Mellen Press, 2000) at 13.
} 
chiefly concerned with the unique nature of totalitarianism and the risks posed by the atomic age. Her analysis of the history of philosophical thought and the many consequences of human action centers around the proposition that freedom can only be realized through the plurality of human beings acting politically, that is, together. In order to understand this proposition three things must be clarified. First, plurality is the condition of men not man. ${ }^{30}$ While man is identical, with common goals and ideas, men are radically different and often in complete disagreement with each other. This leads to the second point: a lack of disagreement in opinion or aspiration eliminates the need for politics and makes man apolitical. ${ }^{31}$ But although it is difference which necessitates politics, this does not mean that the political resides in men. While man is incapable of politics, men do not possess it as an intrinsic quality either. Instead, politics "arises in what lies between men and is established as relationships. ${ }^{.32}$ Politics, therefore, can be framed as a space. It simultaneously exists and makes up the space between people who are distinct and unique from each other. It allows them to live independently of one another and come together to pursue common goals when necessary. Even if individual freedom may seem like the point of politics, it is not the goal or ends of politics. Rather, for Arendt, freedom is "the substance and meaning of all things political." ${ }^{\text {"33 }}$ Freedom can only exist in the 'unique' space of politics.

The understanding of politics as a space between individuals is crucial and should replace the equation of politics with power. The origins of the supposition that politics

\footnotetext{
${ }^{30}$ Arendt's language is not gender neutral. I have nevertheless chosen to adopt it without alteration because the terms 'man' and 'men' most precisely convey the complicated conceptual argument herein.

${ }^{31}$ This is exactly Arendt's fear of totalitarianism. Where men are made into man, politics and freedom are eliminated.

${ }^{32}$ Hannah Arendt. The Promise of Politics. Jerome Kohn eds., (New York: Schocken Books, 2005) at 95.

${ }^{33}$ Arendt, quoted in the editor's introduction, ibid at xxxi.
} 
and power are the same lie in the world's more recent experience with the political. This experience is what Arendt referred to as 'disaster politics.' Just as the volume and intensity of partisan trials eclipsed the previous conceptions of political trials during the twentieth century, so did politics, framed by constant threat of deadly force, eclipse the older understanding of the political as a space for debate. Yet it is not too late to resurrect this older meaning of politics. Similar to the way political trials can be separated from partisan trials, by confirming the presence of the element of risk, so too can politics as a space replace politics as power. In fact, this understanding is far more compatible with what political trials have the potential to accomplish: more than contestations of power, these trials can be an opportunity for testing the legal and social zones of toleration. They provide a regulated space, in the form of court proceeding, within which different social groups and forces can test, and possibly alter, the borders of legal and political identities. ${ }^{34}$ And by understanding politics in this way, we can escape from the framework of political justice as a struggle "between the established power holders and their foes, and generally between competitors for political power," ${ }^{35}$ and return to viewing political justice as a "search for an ideal order in which all members will communicate and interact with the body politic." ${ }^{36}$ We can thereby shift the focus of political justice from its potential for blasphemy to its promise.

In choosing the term political over partisan, I have accomplished two things. First, I have distinguished partisan trials from real political trials which possess the quality of fairness because of the presence of risk. Second, I have contested Kirchheimer's

\footnotetext{
${ }^{34}$ For a discussion of the legal and social zone of toleration see, Eric Tucker "That Indefinite Area of Toleration: Criminal Conspiracy and Trade Unions in Ontario 1837-77" (1991) Labour / Le Travail, Vol. 27: $15-54$.

${ }^{35}$ Kirchheimer, Political Justice, supra note 1 at 3.

${ }^{36}$ Ibid at viii.
} 
construction of political trials as chiefly concerned with the elimination of a political foe. While not denying that some political trials, even those undertaken in rule of law regimes, can be about the maintenance of power, I have argued that the political, understood in this narrow sense, cannot account for all that political trials can promote. Instead, the political should be understood as a space that accommodates debate and discourse and is not limited to the pursuit of power. Having established this, below I move onto the second part of my choice in terminology.

Despite the fact that within most of the literature on the subject, and my own use of the term above, the terms 'justice' and 'trials' intermittently bleed together, they can, and should be, clearly separated. Trials are but one facet of political justice. And although they have a prominent role to play, the wider concept of political justice encompasses much more than political trials can ever respond to or represent.

\section{Justice, not Trials}

Kirchheimer and others demonstrate a slippage between the terms 'political trials' and 'political justice.' Although political justice is meant to be a broader concept, in most cases, the discussion that follows is confined to the domain of trials. This is so for a number of reasons. Courts, while part of the realm of government, carry the label of disinterested arbiter. This presumed impartiality allows them to deliver verdicts that have a certain amount of authority and permanency. And when both sides, as well as the general public, agree to the authority of the court, judicial decisions remove the risk of reprisal and settle the conflict in line with mutually comprehensible rules. Problems arise exactly when this delicate balance is disturbed. When the court's authority is challenged, or the rules are disputed, verdicts in political trials tend to lose their credibility. Despite 
this, the courts offer one option that no other tool available to the constitutional regime can provide. Political trials are the only means through which a constitutional state can legitimately eliminate a political foe permanently. In no other way can a constitutional government kill or remove indefinitely from the public arena a political opponent. Given this, the value of such an instrument cannot be understated. Only through a political trial can a regime "publicize the vileness of the challengers [and] confirm and legitimize the power holders' proposal for disposing of their opponents.",37

But if politics is about much more than the pursuit and protection of power, then the discussion of political justice cannot be limited to trials. Political justice "stresses more the coexistence of different competing social discourses than the direction in which the balance is tipped. ${ }^{38}$ Politics conceived of as a space for competing ideas allows us to expand the concept of political justice beyond the category of trials. The practical considerations surrounding recent political transformations of formerly repressive regimes further necessitates this break with a paradigm that sets out trials as the only facet of political justice. The nature of these transitions, sparked from within the old regime, has meant that post-Communist states in Eastern Europe generally rely on noncriminal and administrative uses of the law as opposed to criminal trials. Apart from the nature of transition, other obstacles, including a lack of applicable legislation, the difficulty in singling out individuals from the state machinery, or even providing conclusive evidence of acts that are sometimes over half a century old, also exist. While some argue that trials bring a "minimal degree of justice [and represent] a moral

\footnotetext{
${ }^{37}$ Kirchheimer, Political Justice, supra note 1 at 420 .

${ }^{38}$ Voiculescu, supra note 29 at 21.
} 
obligation...to the victims of Communism,"39 they can also be dangerous in newly forming democracies because they have the potential to rehash a painful history and divide a population along the lines of old allegiances. The absence of criminal prosecutions, however, does not at all mean that transitional regimes lack political justice. If a broader understanding of political justice framed as a public debate or contestation of ideas, identities, and social discourses is applied, one can see that cases of political justice abound. Truth commissions, constitutional challenges, lustrations, electoral reforms, NGOs concerned with the exploration of history and memory, are all facets of political justice. They, just like political trials, examine and probe the most fundamental values of a society. They do this in an open, public way, with a multitude of voices. More importantly, these examples of political justice do not hold as their end the elimination or imprisonment of a political foe, but are concerned with the discussion and refinement of political and social values, and collective identity and memory. They are, therefore, about more than just power.

"Trials can be interpretive moments for a society. ${ }^{, 40}$ This is especially true of political trials. They challenge the authority and legitimacy of a state or system of government by contesting some of the most fundamental values of society in a court of law, where the result cannot be foretold in advance. The success of the state or defendant has real implications for the way a society defines itself and the standards by which it measures its citizens. Yet interpretive moments for a society are not always marked in a courtroom. Through choice or circumstance, some social upheavals, even some revolutions, are not debated within the confines of the penal system. This makes these

\footnotetext{
${ }^{39}$ Voiculescu, supra note 29 at 23.

${ }^{40}$ Christenson, supra note 2 at $\mathrm{xv}$.
} 
moments no less 'interpretive' or significant. When political justice happens outside the courtroom, it is perhaps less obvious, but it can be even more impactful. Political justice in all of its forms, from truth commissions, to constitutional and rights challenges, and public debates surrounding the legacy of a previous regime, is "consciousnesstransforming." ${ }^{, 41}$ I contend that by prying open the public sphere, highlighting and focusing public discourse, and allowing for challenges to historical narratives and national identity, political justice provides the opportunity for the redefinition of a polity. This is what Kirchheimer called the 'promise' of political justice and what Leora Bilsky termed its 'transformative potential.' In the last section of this chapter I explore, using two examples from Bilsky's work, how political justice facilitates transformation.

\section{Transformative Potential}

Political justice is intricate and multifaceted; it is a definition, conceptual construct, tool of analysis, and mechanism of change. Thus far I have been concerned with what political justice is and how to best define it so as to transcend the central concern of power. I now turn to the performative capacity of political justice. I argue that political justice can facilitate the redefinition of a national identity and collective memory, thereby leading to the transformation of a polity. The opportunity to transform a polity is necessary within a state where the political has not stagnated, but in times of political alteration and transition, political justice takes on even greater importance because it provides for the chance to reckon with the past. This reckoning, as I have already suggested, marks a moment of clear separation from the old and reconstitution of the new. Importantly, however, while it embodies the potential for change, political

\footnotetext{
${ }^{41}$ Bilsky, supra note 5 at 3.
} 
justice in no way ensures the redefinition of a polity. The process of transition from dictatorship to democracy in Russia is evidence of the latent, but unrealized, capacity of political justice to bring about political transformation. And despite the fact that political transformation has not occurred in Russia, neither the impact nor the importance of political justice is lessened.

Why and how political transformation did not take place after the collapse of the Soviet Union will be examined in the third and fourth chapters of this thesis.

Nevertheless, the nature of attempting political transformation remains a central concern here. Although it is desirable that democracy should be promoted through the mechanisms of political justice, it is the process, prospect, and potential for political redefinition and re-evaluation that really matters. The outcome of political justice, due to the presence of risk and unpredictability of all action, can never be predetermined. However, for political justice to have meaning and value, its risky nature has to be accepted and embraced. The concepts of natality, judgment and action, all of which comprise the crucial transformative potential of political justice and simultaneously imbue it with unpredictability, will be closely examined in the next chapter. In order to illustrate the above described potential of political justice here, however, I focus on Leora Bilsky's discussion of the Kastner and Eichmann trials and the ramifications of successful political justice.

Bilsky's book, Transformative Justice: Israeli Identity on Trial, explores four trials: the Kastner trial, the Eichmann trial, the Kufr Qassem trial, and the Yigal Amir trial. All of these trials in some way attempted to, or succeeded in, renegotiating Israeli collective identity and liberal democratic values. Bilsky argues that they responded to the 
central question: "Can Israel be both Jewish and democratic?"42 Although Bilsky's analysis concentrates on trials, the observations and conclusions she reaches are nonetheless applicable to the broader concept of political justice discussed above. This is because these conclusions illuminate a discourse of competing political dialogues expressed through a judicial process, and are therefore not limited to a simple contestation of power. Instead, these trials provided an opportunity to examine Israeli collective identity and memory. And in both cases, narrative and counternarrative played an important role in making up the 'political quality' of the trials exemplified by competing discourses of memory, history, remembrance and identity. The trials also demonstrated the difficulty in judging the contribution of political justice by predicting its outcome or ultimate impact. The existence of a counternarrative provided by Arendt during the Eichmann trial in particular, subverted, to a certain extent, the prosecution's ultimate goal of education.

The 'Kastner Trial' took place in 1954 and is officially known as the Attorney General v. Malchiel Gruenwald case. Formally, the trial was a criminal libel case brought by the Attorney General on behalf of Rudolf Kastner against Malchiel Gruenwald. Unofficially, this was the first trial in Israel that dealt coherently with the narrative of the Holocaust and addressed the question of "how the period of the Holocaust should be presented to the Israeli public." ${ }^{, 43}$ Both Kastner and Gruenwald were from Eastern Europe, and had moved to Israel after the end of the war. In 1955, Kastner was running for political office for the third time and despite his previous losses, his chances of being elected this time around were good. Gruenwald, who had lost most of his family in the

\footnotetext{
${ }^{42}$ Bilsky, supra note 5 at 1 .

${ }^{43}$ Ibid at 79.
} 
Holocaust and who was a devoted member of the Ha-Mizrahi, a Zionist movement, undertook a campaign to denounce Kastner as a Nazi collaborator for his role in the infamous blood for trucks negotiations with Adolf Eichmann. Gruenwald compiled and distributed a pamphlet that claimed Kastner had personally benefitted from the negotiations with the Nazis. ${ }^{44} \mathrm{He}$ further claimed that Kastner had colluded with the Nazis to steal money and had later favourably testified on behalf of a Nazi officer during the Nuremberg Tribunals. To rescue both his reputation and his fledgling political career, Kastner sued. The trial became known as the 'Kastner trial' due in large part to the ability of Gruenwald's attorney, Shmuel Tamir, to claim truth as an absolute defence and put Kastner in the role of accused.

Beyond these broad strokes the specific details of the case that unfolded are unnecessary here. What is interesting and relevant about the case is the way that the history of the Holocaust was re-examined, tied to the present, ${ }^{45}$ and allowed to impact Israeli national identity. In this trial, a traditional dichotomy between the 'Zionist Jew' of Israel was pitted against the 'Diaspora Jew,' was replaced by an arguably equally false dichotomy of leadership versus the masses. The lawyers, specifically Tamir, neatly divided a complicated and mixed history into a black and white contest between the survival of the well-off few and the death of the unlucky many. This simplification and re-interpretation of history was then translated into a shifted understanding of Israeli identity by demonstrating that non-resistance was not the fault of so-called 'ordinary

\footnotetext{
${ }^{44}$ Bilsky, supra note 5 at 21.

${ }^{45}$ Although I do not go into this discussion here, it is important to note that Tamir was able to link the negotiations between various Jewish groups and the Nazis during the war to the recent negotiations over reparations between the Mapai party of Israel and the German government. Tamir had more than historical significance in mind. His political agenda was mainly centered on discrediting the Mapai party. It is not surprising then, given that Kastner was running on a Mapai platform, that he became the stand in representative of an entire party policy.
} 
Jews' but rather the 'Jewish leadership.' In fact, Tamir was actually able to reverse a prevalent bias in Israel against survivors, long held to be suspect by virtue of their survival. ${ }^{46}$ "Tamir transformed the 'ordinary survivors' into reliable witnesses who were perceived by the public as doubly wronged - once by their Nazi prosecutors and again by Israeli prosecution." ${ }^{, 47}$ Discrediting the 'respectful' witnesses of the prosecution by questioning the role that their respectability played in their survival, suggesting that they survived at the expense of less prominent or powerful Jews, Tamir not only put Kastner on the defensive but also transmitted a social and political message to the wider Israeli public. It can be argued that while Tamir oversimplified history in the courtroom, this simplification actually contributed to the formation of a more complex collective identity for Israelis, an identity that no longer fell along the lines of resistance and compliance. The Kastner trial, a concrete example of political justice, facilitated a re-interpretation of history and of collective identity.

I want to briefly note a connection here that will be made more explicit in chapter four. In November of 1992, the Russian Constitutional Court heard a case, the so-called 'trial of the Communist Party of the Soviet Union (CPSU),' which, like the Kastner trial, attempted to re-tell a history of triumph, survival and victimhood. Yet during the trial of the CPSU, it was the Communist party defenders who ultimately succeeded in shaping history for a political purpose. The democratic opposition was unable to gain a foothold within the narrative; instead they focussed on the many, but isolated and seemingly unconnected, human rights violations and atrocities committed by the Soviet regime.

\footnotetext{
${ }^{46}$ As Primo Levi wrote: "the worst survived, that is the fittest: the best of all died." The Drowned and the Saved. (New York: Summit Books, 1988) at 82.

${ }^{47}$ Bilsky, supra note 5 at 31 .
} 
Unlike Tamir, the Russian democrats could not connect the past and present in an effective and politically useful manner. Consequently, the plight of those repressed during the Communist dictatorship had no impact on contemporary Russian identity. These two cases are not mirror images of course. Israel is not Russia; and a direct comparison cannot be made. But both trials were attempts at resurrecting history for a political purpose. And yet, one trial broadened collective identity through the retelling of a history of suffering, while the other narrowed it by shutting out a history of suffering from the historical narrative.

The second trial that Bilsky explores in her book, one that also demonstrates the transformative potential of political justice, although stretched over a much longer timeframe, is the Eichmann trial. The basic facts of this case are well known to most. Adolf Eichmann was captured in Argentina by Israeli agents and brought to Jerusalem to stand trial in 1961 for his role in the transportation of Jews first out of occupied territories in Europe and later to concentrations camps. Unlike the inadvertent manner in which the Kastner trial took on political dimensions, the Eichmann trial was always intended, at least by the prosecution, as an 'educational' experience and a vindication of the Israeli state. While the prosecution aimed to present one version of history, to expound that history to the Israeli public, the presence of Arendt, reporting on the trial, provided a different glimpse of events.

"It may be the irony of history that by criticizing the Eichmann trial and its tendency to become a 'show trial' in the hands of the prosecution Arendt contributed to making it a real political trial for her readers. Her counternarrative forces them to contemplate the most serious jurisprudential, moral, and historical dilemmas that were raised by the trial but often hidden from the public eye. 48

\footnotetext{
${ }^{48}$ Bilsky, supra note 5 at 87.
} 
Arendt's criticism of the Jewish councils, her comments on the issue of cooperation, undermined the cohesive narrative of Jewish suffering that the prosecution tried to present over the course of the trial. While Arendt was interested in examining the blurring of the role of perpetrator and victim under the conditions of totalitarianism, the prosecution was interested in portraying a history of the Jewish people who could only escape centuries of persecution through the establishment of their own state. The prosecution linked the past and the present history of Israel by claiming that Israelis must be vigilant against those who would seek to destroy them. Arendt picked up on this motivation in her book Eichmann in Jerusalem: "In the almost daily incidents of Israel's unhappy borders...there was a lesson for those inside Israel... 'It is necessary that our youth remember what happened to the Jewish people.",49 According to the prosecution, the Eichmann trial would not only teach this tragic history, but it would also "ferret out other Nazis - for example, the connection between the Nazis and some Arab rulers." The trial, therefore, would retell a history and link that history to a violent present, defining Israeli identity as one of resilience and resistance. What Arendt did in her report was not so much contest the history presented in the trial as fill in some the missing pieces. She found these omissions dangerous because "gaps in the Israeli collective memory [ ] could undermine the development of a deliberative democracy and might even lead to a recurrence of such tragedies in the future." ${ }^{.1}$ The testimonies of victims during the trial animated the history of the Holocaust and imprinted it on the collective memory of Israelis. By publicizing and bringing to the forefront some of the less noble

\footnotetext{
${ }^{49}$ Hannah Arendt. Eichmann in Jerusalem: A Report on the Banality of Evil. (New York: Penguin Books, 2006) at 10.

${ }^{50}$ Ibid.

${ }^{51}$ Bilsky, supra note 5 at 103.
} 
aspects of the past, Arendt's competing counternarrative prevented, to a certain extent, a manipulation of history and memory. Both the trial and Arendt's narrative, or perhaps more accurately a combination of both, provided the elements of political re-evaluation and redefinition.

The way we remember the Eichmann trial, as well as where we remember it, is further evidence of the inherent risk for the state in all political justice. Although the prosecution won its case and was able, to a large degree, to teach the history it set out to, Arendt's counternarrative prevented the trial from completely fulfilling the role of 'educational instrument.' The questions raised in her report continue to resonate against the values held up so prominently by the Israeli prosecution. But they do so largely outside Israel, where Arendt's report has been widely published. Inside Israel, Arendt's counternarrative has just begun to emerge in public discourse, after being translated into Hebrew some forty years after first being published. Nonetheless, the Eichmann trial is lasting proof that while political justice offers the opportunity to re-evaluate history and on that basis reform collective identity, when, where, or the way in which this comes about can never be ensured ahead of time.

\section{Conclusion}

Political justice is an attempt. It is a mechanism through which the redefinition and transformation of a polity can potentially be achieved. There are no guarantees of success in political justice. But if politics is the space between people, the substance of relationships, then the fundamental purpose of political justice is to open room for debate. Success, under these conditions, is a subjective secondary concern; what matters is the attempt. In this chapter, I traversed the sometimes difficult terrain of defining and 
understanding, weeding out political justice from its historical and polemic confines. I have both adopted and refuted parts of Kirchheimer's theory of political justice. By way of conclusion, however, I want to now return to what Kirchheimer understood as the promise and blasphemy inherent in the link between politics and justice.

Kirchheimer concluded his essay "Politics and Justice," published six years before Political Justice and capturing many of the same themes, in this way:

"Exercise of authority without consent may at times become inevitable. Yet this very configuration engenders the everlasting process of revision. Therefore if I were asked whether there is any rewarding feature in political justice, my answer would be what is at the same time the most serious reproach against it: that it forever lacks the element of finality." 52

I want to stress that it is this constant process of, or just the opportunity for, revision that makes political justice so important for both democratically developing and developed states. It is the chance at re-conceiving ourselves in opposition to a history or legacy which can be described as the 'transformative potential' of political justice. Because of this infinite process of amendment, democratic principles can undergo countless alterations; they can expand and contract to encompass all or parts of new identities. Static regimes, ones that lack this flexible quality of re-evaluation, cannot provide individuals with the opportunity for redefinition. These regimes stifle moments of political justice preferring instead a model of undisputed power where identity and memory are prescribed by the state to the people and are not allowed to be disputed by a plurality of voices. Within these regimes, political justice is replaced by partisan trials which simply act to demonstrate for the public the 'prototype' citizen, 'ideal' national identity and 'correct' collective memory.

\footnotetext{
${ }^{52}$ Kirchheimer, "Political Justice," supra note 18 at 398.
} 
Crucially, when freed from its confines of partisanship, and examined on the basis of potential, political justice also offers a way into memory. And memory, which is "a perpetually actual phenomenon...[in a state of] permanent evolution, ${ }^{, 53}$ can also be a tool of constant and critical redefinition and renewal. I began this thesis by looking at the way Russians remember (or forget) their past. And while memory, or more accurately nostalgia, is being used now to prevent political change, the introduction of counternarrative and dissenting voices within the spaces and places of remembrance can turn this process around. Although in the chapters that follow I move further into the Russian past, examining the basis of nostalgia hidden within the un-judged Soviet legacy, in the conclusion I again take up the theme of memory.

In the next chapter I am concerned with the questions that have been central to the discussion of political justice, but have thus far not been sufficiently addressed: What exactly constitutes the 'political quality' of political justice? What about this political quality makes political justice an attempt at transformation rather than the harbinger of it? The answer lies in the theory of natality, which I frame as the moment of simultaneous judgment and rebirth. By focussing on natality, I expand the concept of political justice even further, beyond the trial, truth commission or constitutional reforms. It is with an eye to this expanded understanding of political justice that I continue my discussion.

\footnotetext{
${ }^{53}$ Pierre Nora. "Between Memory and History: Les Lieux de Mémoire" (1989) Marc Roudebush trans., Representations, Vol. 26 at 8.
} 


\section{CHAPTER Two}

\section{RECONCILING NATALITY}

"We see clearly what is ending, but cannot know what it is the beginning of."

Natality is "the new beginning inherent in birth." ${ }^{2}$ In this chapter I am interested primarily in beginnings and those concepts that accompany beginnings: action, plurality, and risk. All, except for an express elucidation on risk, were explored and linked by Hannah Arendt in The Human Condition and Between Past and Future. To the definition of natality as birth, I add the element of judgment, which is expressed in the capacity of thought and is fundamentally attached to the 'originality' of all action. Although these concepts form an important basis for my discussion, my point here is not to simply summarize or elaborate on Arendt's theories. There is a vast amount of commentary already, including several informative works specifically on the concept of natality. ${ }^{3}$ Instead, by utilizing these concepts, I am concerned with 'working out' or reconciling what seems to be an incongruity between my theoretical formulation of political justice and the actual cases of political justice that I examine in the next two chapters. Drawing on natality and action, I connect the theory and case studies by asking: Why was political justice in Russia not transformative?

I intend to grapple with the relationship between a beginning and an end, between that which was expected or intended and that which ultimately happened. This relationship is by no means clear or uncomplicated. Nevertheless, I think that a more

\footnotetext{
'Irena Grudzinka Gross. “The Post - Postsociety.” (2001) Social Research, Vol. 68 (4) at 1081.

${ }^{2}$ Hannah Arendt. The Human Condition. (Chicago: The University of Chicago Press, 1998) at 9.

${ }^{3}$ For works specifically concerned with Arendt's concept of natality see Patricia Bowen-Moore. Hannah Arendt's Philosophy of Natality (Houndmills, Basingstoke, Hampshire and London: The MacMillan Press, 1989), Bhikhu Parekh. Hannah Arendt and the Search for a New Political Philosophy (New Jersey: Humanities Press, 1981) and Jonathan Schell. "A Politics of Natality" (2002) Social Research, Vol. 69 (2): $461-471$.
} 
precise understanding of action, which springs from natality, but which has no determined end, can clarify this relationship somewhat. Ultimately, I argue that it is the unpredictability inherent to all action that makes it simultaneously important for politics and dangerous to it. In this chapter, through the discussion of natality, I build a theoretical framework upon which the events that unfolded in Russia in 1991 can be examined.

That nothing but the faintest semblance of democracy exists in Russia today is clearly evident from even the most cursory observations. However, despite the current circumstances, the central issue of how and why the mechanisms of political justice available at the time of the transition did not fulfill their transformative potential has remained largely unchallenged. Attempts have been made to attribute the lack of political transformation to the economic collapse of Eastern Europe or even to the nature of Russian people. My discussion bypasses these particular arguments and instead aims to re-capture and re-examine the moment of transition. From the perspective of that moment, below I elaborate on the nature of the political by looking at peoples' capacity for action. I then turn to the central concern of unpredictability and offer a preliminary link between the moment of change and the current political situation in Russia. I begin by exploring the space for action, something Arendt referred to as the 'gap.'

\section{A 'Gap,' a Moment}

In 1954, Arendt wrote a collection of essays in which she explored, among other things, the role of tradition and judgment in human affairs. Her introduction laid out the initial problem by describing a 'gap' between past and future. This gap, which she called 
a "non-time-space at the very heart of time,"^ could be entered by a person for only as long as they could withstand the pressure of two forces: that of infinite past and infinite future. Despite the stresses of the gap, a person was able to do more than just enter it; they could introduce a third force. "This diagonal force, whose origin is unknown, whose direction is determined by the past and the future, but whose eventual end lies in infinity, is the perfect metaphor for the activity of thought." What made the gap significant was the fact that it,

"unlike the world and culture into which we are born, can only be indicated, but cannot be inherited and handed down from the past: each new generation, indeed every new human being as he inserts himself between an infinite past and an infinite future, must discover and ploddingly pave it anew [emphasis added]."

But plotting this new course was difficult; most individuals would buckle under the crushing forces of past and future before being able to introduce the third force.

Therefore, the problem of how to act within this gap was left to philosophers. For everyone else, the presence of tradition helped to alleviate the pressure and 'bridge' the gap. Arendt pointed out, however, that since Roman times tradition had worn thinner and thinner, eventually breaking and making the gap a fundamentally 'real' experience for all of us. "It became a tangible reality and perplexity for all; that is, it became a fact of political relevance."7

Although Arendt's main purpose lay elsewhere, I think the imagery of the gap aptly illustrates and connects with some of her later discussion on the subject of action. For, if the gap is an ever-present possibility and if, when in it, we are forced to make our

\footnotetext{
${ }^{4}$ Hannah Arendt. Between Past and Future. (London: Penguin Books, 2006) at 13.

${ }^{5}$ Ibid at 12 .

${ }^{6}$ Ibid at 13 .

${ }^{7}$ Ibid.
} 
own path without the guidance of tradition, then what is truly experienced in the gap is freedom: the freedom of action. It should be noted that the experience of being within this gap is a dual one. It allows us to both look into the past and begin anew, thereby combining the activities of thought and action. It is within this gap that we can experience natality, a concept that I will return to below.

The problematic aspect of the gap presents itself when one tries to predict or pinpoint the emergence of this phenomenon. It seems that the gap only becomes visible, or capable of being experienced, at certain times, namely in moments of political upheaval. Although Arendt never acknowledged this outright, she hinted at it through a discussion of the French Résistance fighters during World War II. These individuals were able to capture for a brief moment a 'treasure' which allowed them to "create that public space between themselves where freedom could appear. ${ }^{\prime 8}$ In other words, they stood in the gap and introduced the third force: action. Through 'deed and word' they created a public realm inspired by their experiences of the past and present, and containing unlimited potential. These fighters were fundamentally different from the Allied troops, because in addition to resisting occupation and dictatorship, they "had become 'challengers,' had taken the initiative upon themselves and therefore, without knowing or even noticing it, had begun to create." 9 They, therefore, existed in the gap.

But the gap, the moment for action, is fleeting and "under the most varied circumstances, appears abruptly, unexpectedly, and disappears again." ${ }^{\prime 0}$ And so after the war's end, these people were thrown back into their everyday lives where political debate disintegrated into ideological strife. Nevertheless, what they created while in the gap was

\footnotetext{
${ }_{9}^{8}$ Arendt, Between Past and Future, supra note 4 at 3.

${ }^{9}$ Ibid at 4.

${ }^{10}$ Ibid.
} 
not a waste or forgotten. The ideas and freedoms experienced in the moment of the gap continued to resonate and impact the future. The example of the French Résistance illustrates that the emergence and close of the gap is unpredictable, often only visible retrospectively, and can perhaps most appropriately be expected in moments of extreme political and social uncertainty. Given this, I propose that such gap, a moment of change, opened in 1991 on the streets of Moscow and across Russia.

I suggest this for several reasons. A combination, well documented at this point, of global events, rapid domestic political change, economic instability, and spontaneous and communal expression of public opinion, brought the gap into reality. Without combing through all the specifics, some of which I will elaborate on in the next two chapters, I want to briefly discuss a few of them now.

\section{The Gap as Reality, and the Problems of History}

Mikhail Gorbachev holds the dubious honour of being the last General Secretary of the Communist Party of the Soviet Union and the first, and only, President of the Soviet Union. It was his program of modest reforms, begun in 1985, which sparked a chain of events that would eventually render their author superfluous. Gorbachev's program, perestroika - literally reconstruction - consisted of slow and steady strengthening of the Soviet system through economic acceleration, organizational restructuring, and greater transparency. It amounted to "making the system more efficient without fundamental changes." of his own experience within the Party, that the Soviet system was too heavy-handed and needed to permit initiative and ideas, even criticisms, to come from below.

\footnotetext{
${ }^{11}$ Ronald Gregory Suny eds.. The Structure of Soviet History: Essays and Documents. (New York and Oxford: Oxford University Press, 2003) at 403.
} 
There is still a great deal of debate about how 'revolutionary' Gorbachev was in his thinking. Some have suggested that what he was aiming for was nothing short of “turn[ing] Russian history upside down...teach[ing]...people to rule themselves, something they have never been permitted to do throughout history." ${ }^{12}$ It seems more likely however, that what Gorbachev was trying to achieve was a stable regime, one that would be more engaged with the outside world. To realize this inside Russia, Gorbachev created more democratic institutions, locally elected offices and even the office of President, to which he was elected in 1990. Some of these changes, like the establishment of an official procedure for the secession of republics, were forced on him. From 1986 on, the Soviet Bloc had been slowly disappearing as a system of alliances as various socialist countries failed to re-elect their USSR backed Communist Parties. After the reunification of Germany, nationalistic and ethnic tensions increased in the various Soviet republics as people demanded locally elected leaders in place of Kremlin-appointed ones. At the time, Gorbachev had failed to act with any certainty on the issue. He neither recognized the republics as sovereign, nor was he willing to intervene politically or militarily in local affairs. The result was that by early 1991 , all the republics had either effectively separated, or declared their intention to separate.

The real 'break' came in August of 1991 when the power at the center of the USSR evaporated. A coup led by a small group of Communists unhappy about the reforms and the collapse of the Soviet Union confined Gorbachev to his summer house and went on television to declare him unfit to govern. Their take-over was thwarted by the quick actions of Boris Yeltsin and the largely spontaneous and unprecedented coming

\footnotetext{
${ }^{12}$ Jack Matlock Jr., Autopsy on an Empire: The American Ambassador's Account of the Collapse of the Soviet Union. (New York: Random House, 1995) at 66.
} 
together of people in defence of democratic reforms. The essence of the moment was perhaps best captured by the barricade that went up around the Russian parliament building, also known as the White House. The hastily assembled fence was made up of building supplies, public busses and anything else people brought to the site. It was manned by protestors day and night to prevent the storming of the building by the army. The coup attempt and the stand-off ended on a day proclaimed 'Freedom Day' by the Russian Duma. Soon afterwards, Russian television broadcast unedited and uncensored footage of the deaths of three pro-democracy protestors as well as Yeltsin's speech made from atop a tank. ${ }^{13}$ In the next few days, statues of Soviet heroes were toppled by groups of people and squares all over the country were renamed 'Freedom Square.' A few days later, Gorbachev announced the disbanding of the Communist Party. By December of 1991, the dismantling of the Union of Soviet Socialist Republics was made official through the signing of the Agreement Establishing the Commonwealth of Independent States. On December $25^{\text {th }} 1991$, Gorbachev resigned as the President of the now defunct USSR. He made a televised speech in which he seemed to provide an apt warning for the future:

"The old system collapsed before a new one had time to start working...It seems vitally important to me to preserve the democratic gains of the past few years...Under no circumstances and on no pretext can they be given up. Otherwise, all hopes of something better will be buried."14

A combination of factors made 1991 a year of transformation. Like the Résistance fighters, people all over Russia had acted to create through 'word and deed,' operating in

\footnotetext{
${ }^{13}$ For an analysis of the media's role in the events of August 1991 see Victoria Bonnell and Gregory Freidin. "Televerot: The Role of Television Coverage in Russia's August 1991 Coup" in Nancy Condee eds., Soviet Hieroglyphics: Visual Culture in Late Twentieth-Century Russia. (Bloomington and Indianapolis: Indiana University Press, 1995).

${ }^{14}$ Mikhail Gorbachev. Rossiskaia gazeta. (December 26 1991) in Current Digest of the Soviet Press, Vol. 43 (52): 1-3.
} 
the gap between past and future. In a political vacuum and against the backdrop of a possible authoritarian take-over, individual citizens resisted and formed a public space in which truly new actions could be taken. The moment passed, however, and democratic leaders once united against the coup fell into their old alliances. The country descended into a serious economic crisis and people grew tired of the perestroika rhetoric.

It would be convenient to view the history of the Soviet Union as leading to its eventual collapse, to see the repressive system as the ultimate disappointment, to assume that failure was "built into the story at every point." 15 And this tendency has led more than a few people to construct grand narratives of the demise of socialism, to write books about the "communism's irreversible historical decline [that] will have made its practice and dogma largely irrelevant to the human condition." ${ }^{, 16}$ The problem of course is that judging history is not quite so painless nor so simple. Success and failure of a political or social movement are never a guarantee. A coherent linear story that ends with the breakup of the USSR is perhaps easier to construct in retrospect, but to assume that the breakup was inevitable, or that democracy lay on the other side of it, is a mistake. The collapse was unexpected, by no means predestined, and did not usher in a liberal democracy in Russia or foreshadow the downfall of communist regimes around the world. In fact, a moment of political upheaval that seemed at the time to be full of promise and the spirit of change, in the end did not produce or even facilitate either. At roughly the same time that people were dismantling the barricades around the White House, a report by the Politburo Commission was made public and an important constitutional challenge began

\footnotetext{
${ }^{15}$ Suny, supra note 11 at xi. For an example of these kinds of narratives, see Martin Malia. The Soviet Tragedy: A History of Socialism in Russia: 1917-1991. (New York: The Free Press, 1994).

${ }^{16}$ Zbigniew Brzezinski. The Passing of an Illusion: The Idea of Communism in the Twentieth Century. (Chicago: University of Chicago Press, 1999) at 1.
} 
to be formulated. Both would be examples of political justice and neither, for different reasons, would produce or even initiate political transformation. Given this, the central question becomes: how can a necessarily retrospective analysis of this period be made without falling into the rhetoric of providence or the framework of judgment?

I think that the answer lies somewhere in the unpredictable space between beginnings and endings. In order to consider the problems of unpredictability, judgment, and beginnings I return now to Arendt. Below I examine natality and action, both of which provide a framework for understanding political transformation in Russia. While in the end I offer an opinion as to the factors which contributed to the failure of political justice in Russia, the problem I am interested in here deals not with what should have happened, but with what could have happened and, ultimately, what could still happen.

\section{Natality and Action}

Arendt has been called the 'theorist of beginnings,' the 'thinker of dark times,' and the "unlikely prophet of revolutions. ${ }^{, 17}$ Because Arendt was not a simple theorist, or concerned with 'resolving' the issues she discussed, the task of explaining or using her concepts is a difficult one. Nevertheless, in this section I look at natality in and out of context, in isolation, combined with judgment, and as a component to the larger implications of action. I think that it is only in this somewhat tangled way that the true value of natality as a concept can be demonstrated and the possible consequences of action properly understood.

In order to begin the discussion I have to backtrack to a condition of politics mentioned in the first chapter: plurality. Plurality is central to most of Arendt's

\footnotetext{
${ }^{17}$ By Margaret Canovan, Jerome Kohn and Jonathan Schell, in that order.
} 
discussions and expresses the fact that individuals, at once both alike and completely distinct, inhabit the world. "While all aspects of the human condition are somehow related to politics, this plurality is specifically the condition - not only the condition sine qua non, but the condition per quam - of all political life." ${ }^{, 18}$ I discussed plurality as a condition of politics in the first chapter in order to separate the concept of politics from the concept of power, instead suggesting that politics is a space where many concerns, including power, co-exist. This understanding of politics as space can be taken even further, into the realm of action. As plurality acknowledges the difference of people, politics inhabits the space between them, and action forms the central means of operation in that space.

At this point, it should also be clarified that the gap, which arises in moments of political turmoil and presents the opportunity for natality, is not the same as the general space in which politics exists. Both the gap and the space of politics exist because individuals are different from each other but share common interests, and they are also both areas in which the human capacity for action is the central operating mechanism. But while the space of politics is almost always in existence, with the exception of totalitarian regimes which eliminate (or seek to eliminate) the condition of plurality and therefore the space of politics, the gap is a rarer phenomenon. As mentioned above, the gap becomes a fact of reality, something that can be experienced, only in certain situations. Nevertheless, the two share in common the pre-eminent importance of action. Action, according to Arendt, is the most human and the most political of all activities. "To act, in its most general sense, means to take the initiative, to begin...Because they are

\footnotetext{
${ }^{18}$ Arendt, The Human Condition, supra note 2 at 7.
} 
initium, newcomers and beginners by virtue of birth, men take initiative, are prompted into action. ${ }^{19}$ Here we can see the fundamental connection of birth and beginnings, the condition of natality, to action. With this connection made, I want to pause here to more closely look at natality before returning again to action.

Natality is a concept full of distinct but interrelated meanings. It is first and foremost the experience of birth, the beginning of the beginner. From this first beginning, we embark on a life of other beginnings. Importantly, natality, and therefore action, unlike labour and work, is not forced upon us or conditioned by the presence of others. Like mortality, which is the other fundamental human condition, natality is natural and independent of the other conditions of life. Yet natality cannot be understood solely as the natural process of birth. The political formulation of natality comes from the equation of beginnings with initiative. While birth is the beginning of the beginner, it is not the product of his initiative. Every action that springs from that earliest beginning, however, is the product of the beginner's initiative. Political natality, therefore, is the individual's ability to act. "With word and deed we insert ourselves into the human world, and this insertion is like a second birth, in which we confirm and take upon ourselves the naked fact of our original physical appearance. ${ }^{, 20}$ We thereby respond to our original beginning by continuing to begin anew.

Apart from action, expressed through beginnings, natality is also linked to thought. Because through the process of birth we embody 'newness,' the original beginning, we are perfectly positioned to judge those things already in existence or those things just created..Arendt started to consider the human capacity for judgment in relation

\footnotetext{
${ }^{19}$ Arendt, The Human Condition, supra note 2 at 177.

${ }^{20}$ Ibid at 176 .
} 
to Kant's philosophy almost a decade before writing Eichmann in Jerusalem in which she advocated for the right to judge the crimes committed by Hitler's regime. ${ }^{21}$ But wherever its origin, Arendt's argument in favour of novel judgment rests largely on an understanding of the importance of natality:

"Even though we have lost yardsticks by which to measure, and rules under which to subsume the particular, a being whose essence is beginning may have enough origin within himself to understand without preconceived categories and to judge without the set of customary rules [emphasis added]. ${ }^{.22}$

Natality, therefore, can be framed as a condition inherent to everyone by virtue of birth, and fundamentally embodying initiative, whether through action or thought. Furthermore, natality, although it exists in the everyday spaces of politics, becomes vitally important in those moments when the gap emerges. In the gap, natality becomes an instrument of reckoning where an individual stands between the forces of past and future, looks backward and starts anew. The third force in the gap, that of action, is rooted in the dual function of natality as judgment and initiative. It is for this reason that I equate natality with the process of reckoning.

Thus far I have only dealt with the origin of action, namely natality. Yet the problematic elements of this theory of action only become truly evident when one looks past the beginning and wonders why, if it has such seemingly conscious decision-based starting point, does action so rarely turn out as intended? In other words, what makes the road between beginning and end so treacherous? The answer, once again, lies in that essential condition of the political: plurality. Plurality not only describes people's

\footnotetext{
${ }^{21}$ For a discussion of the role of judgment in relation to the Holocaust, see Hannah Ardent. "Social Science Techniques and the Study of Concentration Camps" (1950) Jewish Social Studies, Vol. 12 (1): 49 - 64.

${ }^{22}$ Hannah Arendt. "Understanding and Politics" (1953) Partisan Review, Vol. 20 at 377. In her book Transformative Justice, Leora Bilsky links natality, plurality and narrative to form a theory of 'reflective judgment' which correlates to Arendt's theory of 'enlarged mentality.'
} 
difference but also explains a web of relationships that springs up between individuals due to that innate difference and subsequent need to interact. This web of relationships is complicated, because while people may be working together to achieve some goals, they may also be working individually to achieve other goals, or with others to block actions they disagree with. Thus, once the author of an action acts on their original intention and begins something, they cannot remain the only person involved. The involvement of others leads to what Arendt referred to as the inevitable 'unpredictability of action.' Because action is not like labour or work, it can 'make' nothing. Instead, action produces or causes consequences which are boundless.

"Human action, projected into a web of relationships where many and opposing ends are pursued, almost never fulfills its original intention; no act can ever be recognized by its author as his own with the same happy certainty with which a piece of work of any kind can be recognized by its maker. Whoever begins to act must know that he has started something whose end he can never foretell., ${ }^{23}$

To conclude that all action is ultimately unpredictable or risky may seem axiomatic, but the consequences of this proposition are tremendous for any social, political or historical analysis. Accepting that actions are unpredictable and that their authors exercise little to no control over them after their initial beginning precludes us, to a certain extent, from using a broad or general retrospective gaze in order to examine events. And yet this has been done repeatedly, most often through the confusion or collapse of the means / ends distinction. I address this last important implication of unpredictability here before turning to the 'remedies' of action and what they mean for understanding political justice as well as moments of natality.

\footnotetext{
${ }^{23}$ Arendt, Between Past and Future, supra note 4 at 85.
} 


\section{Distinguishing Means (and Meaningfulness) from Ends}

"The danger of transforming the unknown and unknowable 'higher aims' into planned and willed intentions [is] that meaning and meaningfulness [are] transformed into ends. ${ }^{24}$ I have already mentioned that action is not labour or work, the other two subjects of Arendt's The Human Condition. Action therefore does not, and cannot, 'fabricate' a result in the same way that work or labour can 'make' a recognizable object. Nevertheless, we undertake actions with certain goals in mind. These goals, however, should not be understood as imbuing our actions with 'meaning.' Arendt's discussion of this is both illuminating and confusing - often simultaneously: "Meaning, which can never be the aim of action and yet, inevitably will arise out of human deeds after the action itself has come to an end. ${ }^{, 25}$ I think that in order to clearly understand the distinction made by Arendt, one must carefully pull apart the terms 'means' and 'meaning.' Means are those mechanisms through which we act in order to bring about a result. Meaning is ascertained only after the action is complete. Consequently, how meaningful our actions are can only be judged in retrospect. ${ }^{26}$ And while we have some control over the means, we have, as authors of action, as little control over the meaningfulness of an act as we do over the ultimate outcome of that act. Accordingly, meaningfulness is more akin to ends than to means.

In order to illustrate this in more solid terms, I want to return briefly to the problem of historiography. The faulty nature of an analysis which seeks to impose a 'destiny' for the sake of historical narrative onto unconnected, or only loosely connected

\footnotetext{
${ }^{24}$ Arendt, Between Past and Future, supra note 4 at 78.

${ }^{25}$ Ibid.

${ }^{26}$ The entire problem for Arendt is more directly connected to Marx's 'take' on Hegel. In the context of the philosophical tradition, Arendt was concerned with the tendency of 'deriving politics from history, or rather, political conscience from historical consciousness.'
} 
actions, takes its lead from this collapsed understanding of means and meaningfulness. For the sake of narrative or 'historical lessons,' these kinds of analysis shrink from acknowledging the totality of unpredictability. ${ }^{27}$ Instead, the drive to pull out a comprehendible thread from chaotic historical events proves too attractive to be ignored. Let me be clear: I am not suggesting that Arendt argued, nor am I arguing myself, that a history or histories do not exist or that events should not be examined, either as they unfold or retrospectively. Arendt was quite plain about this fact: "Even if we admit that every generation has the right to write its own history, we admit no more than that it has the right to rearrange the facts in accordance with its own perspective; we don't admit the right to touch the factual matter itself." ${ }^{, 28}$ The problem arises with the suggestion that certain events are inevitable or were 'led up to' through history. The classic Arendtian example is Marxism and the worker's revolution but my particular example here is the fall of the Soviet Union. I think the events of 1991 concretely demonstrate that action is unpredictable, especially in the political realm and at a time of international instability. It is possible that had the members of the August coup not overreacted to Gorbachev's reforms, which were themselves relatively timid, the disbanding of the CPSU would not have happened. It is equally plausible, however, that the economic problems inside Russia were so deeply sewn into the infrastructure of the state that they would have proven fatal to the system with or without the August events. This is mere speculation and there are enough historical and political polemics on both sides to make either case. My point is simply that the end of the USSR should not be viewed like some force of

\footnotetext{
${ }^{27}$ See for example Gail Sheehy. The Man who Changed the World. (New York: Perennial Library, 1990). This is a biography of Gorbachev that suggests his actions, and sometimes erratic behaviour, were a result of 'male menopause.'

${ }^{28}$ Arendt, Between Past and Future, supra note 4 at 234.
} 
nature, which is predictable and yet unstoppable. Each actor and action contributed is some way to the events as they unfolded. And the events of 1990, 1991, and 1992 should be examined within the framework of this understanding.

\section{Conclusion: Reconciling Natality}

Just as political justice holds potential for both promise and blasphemy, so too do the problematic elements of action that cause wrinkles within the analysis also provide a possible way to 'remedy' the situation. Arendt explored three ways of dealing with the consequences of action: forgiveness, promise and further action. ${ }^{29}$ Forgiveness was meant to address irreversibility and unpredictability of action. But it seemed too fragile for the realm of public affairs. Promise, more concretely understood as treaties and agreements, also addressed the unpredictability of action and was an accepted way to make the web of human relations more predictable. However, I am mainly interested in the third resolution to action, that of further action. Arendt argued that even the degradation of all politics into simple means through which to achieve a single end could not eliminate from the world either plurality or action. Therefore, the same danger of action, its capacity for boundlessness and unpredictability, becomes its saving grace. "The strength of the action process is never exhausted in a single deed by, on the contrary, can grow while its consequences multiply...The reason why we are never able to foretell with certainty the outcome and end of any action is simply that action has no end. ${ }^{30}$ At any given point then, circumstances can change and the space of politics can open again for action, for judgment and for natality. Thus, while I argue in the next two chapters that the opportunity for political transformation was missed, I nevertheless

\footnotetext{
${ }^{29}$ Arendt, The Human Condition supra note 2 at pp $230-247$.

${ }^{30}$ Ibid at 233.
} 
propose that this is not a permanent loss. The new terrain of action, new possibilities for political justice and natality that I see in Russia, is in the field of memory and commemoration. This is a place not dominated by state control and one which offers the all important possibility of redefinition. Accordingly, I return to memory in the conclusion of this thesis and suggest it as the next avenue of challenge and change. Yet, even here, I must acknowledge that if memory is the future site of political struggle, there is still no guarantee that the changes made will be in furtherance of a democratic regime. Nevertheless, democracy demands risk. Without risk, no real social, political, or legal gains can ever be made.

In the next chapter I turn to my first case study of Russia's attempted political justice: the report Reabilitatsia compiled by the Politburo Commission on Additional Studies of Documents Pertaining to Repressive Measures of the 1930s, 40s and early 50s. I place the rehabilitation of the $1950 \mathrm{~s}, 60 \mathrm{~s}$ and $80 \mathrm{~s}$ in historical context and focus on the purpose of this political process. My argument is that, although the examination of Soviet history presented the opportunity for a reckoning with the past, the Commission's unwillingness to judge the entire Soviet system resulted in the rehabilitation of the Communist Party, not its victims. 


\section{CHAPTER THREE}

\section{Rehabilitating the Past: The Politburo Commission}

"The prison camp literature tells of the same phrase, 'Why?' often found written on cell walls, and carved into the sides of prison wagons and on the planks of the transit camps.",

"In 1937 one of the grooms on our kolkhoz and one of our team leaders were arrested. I asked my father why. He warned me sternly never to ask anyone about it."2

The total number of victims of the Soviet regime has been estimated to be somewhere between forty and sixty million. ${ }^{3}$ This massive but uncertain number is a testament to three interrelated factors: the span of the regime, wide range of repressions, and a specific understanding of victimhood. It is not surprising that a violent dictatorship that held power for over seven decades left behind a long trail of victims. To add to this problem of duration, the Soviet regime employed a wide range of repressive tactics that varied from murder to imprisonment to exile and the loss of rights. And while most statistics include people sentenced to death or imprisoned in the GULAGs among the regime's victims, few take into account those peripherally impacted like the children and spouses of individuals labelled as 'enemies of the people' who were stripped of rights,

\footnotetext{
${ }^{1}$ Robert Conquest. The Great Terror: A Reassessment. (Oxford: Oxford University Press, 2008) at 445. ${ }^{2}$ A. N. Yakovlev. A Century of Violence in Soviet Russia. Anthony Austin trans., (New Haven and London: Yale University Press, 2002) at 7.

${ }^{3}$ About two million people, mostly Party members and intelligentsia, were summarily executed in purges between 1936 and 1938. Beginning in 1930 and continuing until 1956, eight million people a year passed through the GULAG system, a quarter of them died of starvation, exposure, or were worked to death. Policies of forced collectivisation killed millions of farmers throughout Russia and in the Ukraine where five million peasants starved to death in the man-made famine of $1932-33$. The negligent and brutal tactics of Stalin and his military commanders contributed significantly to the high civilian casualties during WWII. Scholars differ on whether and how many of these deaths should be attributed to the regime or the war itself. It is certain however, that along with the twelve million civilians and ten million soldiers that died during the war, many were severely punished in the post-war years. Those people who remained on occupied territory or were captured during Hitler's advance into the USSR were regarded as traitors after the war and imprisoned or stripped of rights, serving lengthy sentences before being allowed to return home. For a detailed discussion of statistics on Stalinist-era repression see Anne Applebaum. "How Many?" pp. 578 - 586, in GULAG: A History. (New York, London, Toronto, Sydney, Auckland: Doubleday, 2003). Conquest states "the dead [are] no fewer than 20 million. This figure is now given in the USSR. And the general total of 'repressed' is now stated (e.g., in the high-school textbooks) as around 40 million." supra note 1 at 486 .
} 
property, housing, jobs and education. The issue of gradation of repressions is also closely connected to questions of how victimhood is constructed. What level of violence had to be experienced in order to qualify as a victim? Did the repression have to include physical violence to be considered real? These distinctions become more difficult in the context of present day Russia, in which the government has chosen for specific and strategic reasons to downplay the repressive and violent nature of the Soviet regime. As the country continues to exist in a no-man's land between collective victimhood and collective culpability, broader questions of 'why' and 'for what,' which touch upon the very nature of the regime, remain unaddressed.

In this chapter I examine the 1991 government publication Reabilitatsia: Political Processes of the 1930s, 40s and 50s (hereafter Reabilitatsia), a document compiled by the Commission on Additional Studies of Documents Pertaining to Repressive Measures of the 1930s-1940s and early 1950s which was formed by the Politburo on September $28^{\text {th }}, 1987$. It is a collection of archival documents and official assessments on the process of rehabilitation of victims of political repression originally begun in 1953, abandoned in 1961, and begun again in 1987. The Commission was headed by A. N. Yakovlev, a prominent member of the Central Committee and close advisor to Gorbachev, and was charged with "conducting a thorough examination of the facts and documents connected to the repressive measures used in the 1930s, 40s, and 50s." After the collapse of the Soviet Union in 1991, the Commission was renamed the Presidential Commission for the Rehabilitation of Victims of Political Repression and reported directly to the President of the Russian Federation. It continued to work under its mandate, although in a largely

\footnotetext{
${ }^{4}$ A. N. Yakovlev eds., Reabilitatsia: Politicheskie protsessy 30-50kh godov. (Moscow: Politizdat, 1991) at 15. The report was only published in Russian; all translations quoted in this chapter are my own. Page numbers provided for quotes refer to the original text.
} 
diminished capacity, until the death of Yakovlev in 2005.The process of rehabilitation continues today through the Office of the Procuracy; ${ }^{5}$ this office deals with requests for information on those repressed by providing short biographies containing the reasons for arrest and the place of detention or death. There has been no other effort to produce an official rehabilitation report akin to the earlier Politburo document. ${ }^{6}$ As such, Reabilitatsia is Russia's only official, state-produced, and state sanctioned historical retrospective on political repressions of the Stalin era.

It can be safely assumed, and has been widely commented on in transitional justice literature, that truth reports compiled at the end of a violent or repressive period in a state's history are rarely successful at capturing the entire 'truth' of what happened. There are always political motivations and considerations which limit, in some way, the overarching narrative. Conversely, there is also a danger that the complexity of the data can be oversimplified for the sake of the desired socio-political narrative. But even so, the Politburo's report stands apart from others included in this category. It was researched and written while the USSR was still intact and therefore, while it aimed for a certain kind of political transformation, the boundaries of that transformation were clearly, though not explicitly, set out before a single finding was reached. Thus, rather than a straight forward summary of historical events, a chronicle of the stories of victims, or a narrative of reconciliation and transition, this report is a series of careful reflections about the nature and history of the Soviet regime with a particular purpose. Within it, the

\footnotetext{
${ }^{5}$ The Office of the Procuracy has recently stated that the process of rehabilitation is nearing completion with only 600, 000 applications still pending, see Nanci Adler. "The Future of the Soviet Past Remains Unpredictable: The Resurrection of Stalinist Symbols Amidst Exhumation of Mass Graves" (2005) Europe-Asia Studies, Vol. 57 (8): 1093 - 1119.

${ }^{6}$ The group Memorial, which began work in 1986, continues to publish lists of individuals killed or imprisoned during the Soviet regime though it has no official standing to grant 'rehabilitated status.'
} 
Politburo provided a historical narrative which placed most of the responsibility for repressions on Stalin, thereby distancing the Party structure from his conduct. The effort to create a new Party 'image,' one that, on a limited scale, embraced historical honesty and admitted to a measure of criminality, tells a particular political story. This story, although overtly concerned with the past, is meant to facilitate the continuing political relevance of the Communist Party. The overt rhetoric of reform and renewal is further substantiated through the utilization of victimhood. By seizing and appropriating the stories of victims, thereby demonstrating an internal change in the application of Soviet policy, the Party succeeds in rehabilitating itself. This self-rehabilitation constitutes an important narrative of Reabilitatsia.

Given the intersection of reflections contained within this report, I argue that, more than an example of yet another revision of Soviet history by the state, it is a case of political justice attempted. The examination of the past fulfills, to some extent, the first condition of natality, that of judgment, by exploring history in an apparently comprehensive manner. The future-oriented perspective of Reabilitatsia also seems to fulfill the second condition of natality, that of initiative, by creating a separation between old and new state policy on the basis of the discovery of past crimes. Yet, the report is a missed opportunity because, in the end, it makes no clear break with the past. Instead, the Politburo Commission rehabilitated the Party, the core principles of socialism, and the Soviet system, providing a cogent link between past and future. I contend that victimhood, the way certain victims are identified, described, and rehabilitated while others are dismissed or omitted, is indicative of the real purposes of the rehabilitation process and epitomizes the unfulfilled conditions of political justice. By looking at both 
the told and untold stories of victims contained in Reabilitatsia, I highlight the way the Soviet state has continually refashioned its identity. Despite their various incarnations, none of these attempts came close to acknowledging the criminality of the Soviet regime, none examined the role of Lenin or the earliest repressions of the Bolshevik Revolution, and none accounted for more engrained forms of state violence perpetrated by the police and security services. The process of rehabilitation and the construction of victimhood remain, therefore, the ultimate evidence of an incomplete transition from dictatorship to democracy in Russia.

Although my main focus is the last rehabilitation process begun in 1987 because of its significance for, and proximity to, Russia's transition, I have organized this chapter in chronological order following the general structure of the report. This is in part done to demonstrate the cumulative effects of rehabilitation, to contrast the different processes, and to situate them in their historical contexts. Before delving into the background of repressions, however, I must pause to examine the term 'rehabilitation.' This important concept is simultaneously a legal status that carries certain rights and privileges, and a political construct with waxing and waning social value.

\section{Exoneration and Excuse}

Rehabilitation is both more than, and less than, the finding or pronouncement of innocence. Under Russian law, rehabilitation is a means of restoring the honour, reputation, rights, and status of citizens who were "subject to criminal liability or who were convicted or subject to political repression for religious, social, class or other 
criteria." It therefore consists of all, or parts of: formal restoration of rights, judicial annulment of conviction, public restoration of reputation, re-instatement into the Party, reappearance in official state histories, and material compensation. It can take place while the individual is still alive or, as in the case of most people repressed by Stalin, posthumously. Posthumous rehabilitation was one of the first forms of rehabilitation in the Soviet Union and could be judicial, public, or both. ${ }^{8}$ For example, in the 1960 s, Nikoli Bukharin was rehabilitated judicially, through the annulment of his 1938 conviction, but was not rehabilitated publically due to 'ideological errors' in his political beliefs. ${ }^{9}$ As Bukharin's case indicates, posthumous rehabilitation was predominantly used for former Party members included in Stalin's purges; very few of the millions of peasants and workers repressed during the 1930s and 1940s were posthumously rehabilitated.

Before 1953, there were no legal provisions in the USSR for the compensation of those illegally victimized. ${ }^{10}$ As prisoners began to be released from camps following Stalin's death, a series of acts were passed by the USSR Council of Ministers providing for the restoration of rights for those convicted by extrajudicial agencies like the People's Commissariat for Internal Affairs (NKVD) and the State Political Directorate (OGPU). In the 1950s and 1960s most people, after petitioning for rehabilitation, would receive, if approved, a document which detailed the annulment of their sentence and completion of

\footnotetext{
${ }^{7}$ Tat'iana N. Moskal'kova. "Rehabilitation of the Innocent in the Russian Federation" (1992) Review of Central and East European Law, Vol. 18 (5) at 475.

${ }^{8}$ For a detailed discussion of the levels of rehabilitation and three case studies, see Albert P. Van Goudoever The Limits of Destalinization in the Soviet Union: Political Rehabilitation in the Soviet Union since Stalin (New York: St. Martin's Press, 1986).

${ }^{9}$ Jane P. Shapiro "Rehabilitation Policy under the Post-Khrushchev Leadership" (1969) Soviet Studies, Vol. 20 (4) at 489. For a detailed examination of the rehabilitation of former Party members see J. P. Shapiro. Rehabilitation Policy and Political Conflict in the Soviet Union, 1953 - 1964. (1967) Unpublished $\mathrm{PhD}$ Dissertation, Faculty of Political Science, Columbia University.

${ }^{10}$ Moskal'kova supra note 7 at 476.
} 
their case based on one of several formulations: "on account of the unproven nature of the charge, the lack of evidence, or the absence of a punishable act" " also called "a lack of offense." 12 From this gradation of findings it is clear that not all rehabilitations were complete vindications. "[A] distinction can be made between those who were regarded as innocent because their actions, which had led to a conviction at the time, were not punishable, and those whose guilt could not be established." ${ }^{\text {"13 }}$ Thus rehabilitation was not always akin to judicial exoneration, or a declaration of innocence, but was nonetheless practically useful because it led to the re-instatement of rights. The restoration of rights facilitated 'normalization' in the life of a formerly repressed person by lifting forms of administrative punishment, like mobility and employment restrictions. The compensation that accompanied the first rehabilitations was limited to say the least. Regardless of the term of imprisonment, an individual was only entitled to receive two month's salary from the position they held before their arrest. ${ }^{14}$ No confiscated property was ever returned.

By the early 1980 s, Party membership became less and less essential for career advancement or education, and the social value of public rehabilitation, through Party reinstatement, decreased. Nevertheless, both a rehabilitation and compensation schemes continued to be revised and expanded, beginning in 1981 through to 1989 and several times in $1991 .{ }^{15}$ Despite the legislative changes, and even after the collapse of the Soviet Union, the approach to addressing the claims of victims of repression, and the state view on victimhood in general, has remained ambivalent. For example, the criminal code of

\footnotetext{
${ }^{11}$ Van Goudoever, supra note 8 at 43.

${ }^{12}$ For a detailed discussion of one case of arrest, imprisonment, release and second conviction on the same charges of terrorism see Aleksei A. Bayev's tribute to his father Academician A. A. Bayev on the centennial of his birth. "I Don't Admit the Charge" (2004) Molecular Biology, Vol. 38 (2): 298 - 307.

${ }^{13}$ Van Goudoever, supra note 8 at 43.

${ }^{14}$ Moskal'kova, supra note 7 at 477.

${ }^{15}$ Ibid.
} 
the Russian Federation still contains the phrase "failure to prove participation" 16 when describing the procedure for granting a corrective judgment to void a conviction. As in the previous processes of rehabilitation, 'failure to prove participation' is not akin to exoneration and merely suggests that there is a lack of evidence on which to establish guilt. Rehabilitation on this basis does not completely clear an individual of suspicion. Also, while the 1991 law 'On the rehabilitation of victims of political repression' guaranteed a wide range of compensation, including full payment of wages, restoration of housing and employment, increased pension, the return of court fees, and the return of seized property, it disqualifies individuals who, after 1981, confessed to the crime from receiving any of the listed compensation. "The Edict states that damages are not subject to compensation if in the process if preliminary inquiry, investigation, or judicial proceedings a citizen has obstructed the ascertainment of the truth by a confession and thereby prompted the onset of harmful consequences." ${ }^{17}$ Although this statute does not apply to the victims of Stalinist repression, almost all of who were forced to confess or sign false confessions, ${ }^{18}$ it does apply to everyone else who confessed to an offense. Since the use of torture and physical pressure during investigations in the 1930s, 1940s and 1950s is well known, and officially acknowledged, the exclusion of people who confessed in the 1980 s from receiving compensation suggests that the state officially marked the end of the use of physical coercion to obtain confessions in the early 1980 s. The factual accuracy of such a conclusion is difficult to determine; physical coercion may or may not be used within the Russian criminal system. Nonetheless, this legislation

\footnotetext{
${ }^{16}$ Article 208 (2) CPC RSFSR.

${ }^{17}$ Moskal'kova, supra note 7 at 481 .

${ }^{18}$ On the practice of confessing and informing see Golfo Alexopoulos. "Victim Talk: Defense Testimony and Denunciation under Stalin" (1999) Law and Social Inquiry, Vol. 24 (3): 637 - 654.
} 
suggests that other means of coercion, like psychological pressure, are not considered severe enough by the Russian government to shift the liability for a false confession from the individual to the state. A lawyer from the Ministry of Internal Affairs claims that "there is no doubt as to the fairness of this rule in regards, for example, the compensation of property damage: if a person has voluntarily confessed to the commission of a crime, it means that he voluntarily subjects himself to certain material losses."19

The 1991 law for victims of political repressions is also interesting because of its wide scope; it applies to anyone subject to repressions within the territory of the Russian Federation from November $7^{\text {th }}, 1917$, the date of the Bolshevik Revolution. But while the law encompasses a large group of victims, including those subject to forced resettlement, it has limited provisions for reparation, promising only such compensation as is "possible in present day circumstances. ${ }^{, 20}$ Repressed individuals are entitled to 180 rubles for each month of the deprivation of freedom, up to a maximum of twenty-five thousand rubles, or roughly 925 US dollars. Ironically, state officials have argued that it is exactly the volume of potential victims which has necessitated this limit to compensation. Dealing fully with the repressions of the past would bankrupt the current government.

\section{The Return}

Joseph Stalin died on March $5^{\text {th }}, 1953$ after thirty years as the head of the leadership of the Soviet Union. During his reign, he built and perpetuated a cult of personality that became deeply entrenched in Soviet society. Accounts in the 1930s describe Stalin as 'Father of Peoples,' 'Genius of Mankind,' 'Driver of the Locomotive of History,' and 'Greatest Man of All Times and Peoples.' The personality cult

\footnotetext{
${ }^{19}$ Moskal'kova, supra note 7 at 481 .

${ }^{20}$ Ibid at 483 .
} 
eventually reached the point of deification. A typical cult appellation of the early $1940 \mathrm{~s}$

begins with "O Great Stalin, O Leader of the Peoples, Thou who didst give birth to man, Thou who didst make fertile the earth."21 Along with innumerable streets, buildings and towns named in his honour, Stalin's portrait, bust or statue could be found in most public spaces, offices, stores and even homes. ${ }^{22}$ After his death, however, a cascade of revelations about arbitrary mass murder and imprisonment began. ${ }^{23}$ These revelations formed the basis of a process of de-Stalinization, consisting of three distinct parts: Nikita Khrushchev's 'Secret Speech,' public dismantling of the personality cult, and the rehabilitation of victims. All three components were largely necessitated by the mass release of prisoners from the GULAGs. What was at first only a trickle of releases became, by 1956, a torrent with millions of people returning from the camps. The sudden appearance of these men and women pitted "two Russias... eyeball to eyeball - those who were imprisoned and those who put them there." 24 The presence of former prisoners within society represented tangible evidence of the brutal repressions that had been the norm of state policy for more than two decades. Their experiences and stories were "a

\footnotetext{
${ }^{21}$ Quoted by Suzanne Labin in Stalin's Russia (London: Gollancz, 1949) at 65.

22 “.... [he] blinked up with already returning irony at the colour print of No. 1, leader of the Party, which hung over his bed on the wall of his room - and on the walls of all the rooms next to, above or under his."Arthur Koestler. Darkness at Noon. Daphne Hardy trans., (New York, London, Toronto and Sydney: Scriber, 1968) at 5. Koestler's fictional account of the detention, trial and execution of Nicholas Rubashov, a high ranking Party member, is largely based on the show trials of doctors, engineers and Party members that were held in Moscow in 1937 and 1938 for which the author was present.

${ }^{23}$ Even Stalin's burial added to the death toll of his reign. A dozen mourners were killed and several hundred hurt when a crowd gathered to view his remains. For a first-hand account of the fear, panic and en mass hysteria after Stalin's death see Yevgeny Yevtushenko. A Precocious Autobiography. Andrew R. MacAndrew trans., (London: Collins and Harvill Press, 1963) at $89-95$.

${ }^{24}$ Anna Akhmatova. Pamiati Anny Akhmatovoi (Paris: YMCA Press, 1975) at 188.
} 
shock of finding out and being found out. ${ }^{, 25}$ Most former prisoners openly challenged their convictions as 'counterrevolutionaries' and 'enemies of the people.'

"[They] required, and demanded, many forms of rehabilitation - legal exoneration, family reunification, housing, jobs, medical care, and pensions. Their demands were shared by a kindred group of millions of relatives of people who had perished in the terror...Posthumous legal exoneration, or 'rehabilitation,' and restitution were therefore both a practical necessity and a deeply felt duty to the dead. ${ }^{26}$

A wave of prosecutions and expulsions targeting those closest to Stalin, and therefore most responsible for the repressions, started almost immediately. Lavrenti Beria, head of the NKVD, the man chiefly responsible for facilitating the purges of the late 1930s and for the brutal 'cleansing' of the secret police itself, was arrested in June of 1953. Although responsible for perhaps millions of deaths of innocent Soviet citizens, Beria was accused of spying for the British. In a hearing conducted by the Supreme Court of the Soviet Union in 'special session,' and without the right to council or the right to present a defence, Beria was found guilty of treason, terrorism, and counterrevolutionary activities. He was sentenced to death and executed by firing squad on the same day. ${ }^{27}$

\footnotetext{
${ }^{25}$ Nanci Adler. Beyond the Soviet System: The GULAG Survivor. (New Brunswick and London: Transaction Publishers, 2002) at 7.

${ }^{26}$ Stephen F. Cohen. "The Stalin Question since Stalin" in Stephen F. Cohen eds., An End to Silence: Uncensored Opinion in the Soviet Union from Roy Medvedev's Underground Magazine Political Diary George Saunders trans., (New York and London: W. W. Norton \& Company, 1982) at 25.

${ }^{27}$ This is one, widely reported, version of Beria's conviction. The second version began to circulate in Europe and was apparently related by Khrushchev to Pierre Commin, the leader of the French Socialist Delegation that visited Moscow in May of 1956. In this version, Beria was not tried in a session of the Supreme Court but was interrogated at a meeting of the Presidium for four hours before being shot. "Evidence for his [Beria's] consignment to a court we still did not have, yet to leave him at liberty was impossible. We came to the unanimous decision that the only correct measure for the defense of the Revolution was to shoot him immediately. This decision was adopted by us, and carried out on the spot. But we felt much easier when, some time after his condemnation we received sufficient and irrefutable evidence of his guilt." in Bertram D. Wolfe. Khrushchev and Stalin's Ghost: Text, Background and Meaning of Khrushchev's Secret Report to the Twentieth Congress on the Night of February 24-25, 1956. (New York: Frederick A. Paeger, 1957) at 317.
} 
As early as April 1953, just a month after Stalin's death, comments critical of the cult of personality also began to appear in the press and in official statements from the Party. They were the result of early inner-Party debate about how to handle the legacy of Stalin's policies. The forced collectivization of the 1920s and 1930s, along with killing millions of peasants, had run the agricultural sector of the economy into almost complete ruin. The military and police "were pressing to rid their institutional reputation of disgraceful stain's left by Stalin's misrule. ${ }^{28}$ Petitions circulated within the Party calling for the release of prominent Party members that had been imprisoned during the Great Purge and reports streamed in about open rebellion in some of the Siberian and Far East camps. As a result, certain measures needed to be taken by the new leadership of the Party. But at the same time, Stalin's fall from grace threatened to taint the entire system with the air of implied collective culpability. Khrushchev's de-Stalinisation was therefore a careful balancing act. The repressions were officially acknowledged as brutal and largely arbitrary, with both punishment and rehabilitation promised. But responsibility was carefully parceled out so as not to extend to the entire system; the crimes were deemed to be either 'isolated mistakes' or 'excessive measures.' This approach officially emerged during Khrushchev's 'Secret Speech' made on the night of February $24^{\text {th }}$, 1956 at a closed session of the Twentieth Party Congress.

The secret speech, officially entitled 'On the Cult of Personality and Its Consequences,' is included in the second section of the 1991 report, Reabilitatsia, and is significant for a number of reasons. For the purposes of rehabilitation, it is the first comprehensive detailing of Stalin's crimes, including the repression of fellow Party

\footnotetext{
${ }^{28}$ Cohen, supra note 26 at 31 .
} 
members during the Great Purge and his lack of preparedness for WWII. Second, the speech marked a division in the international Communist movement. Although it was a 'secret' in the USSR, not being officially published or mentioned until the early 1980 s, the speech was widely available abroad almost immediately after being delivered at the Congress due to the work of the Israeli and American intelligence agencies.

Consequently, the revelations detailed within it and published in mainstream journals and newspapers in the West caused thousands of people to leave their national Communist parties. For decades, the Party line espoused by the central Moscow authority had been followed and defended, sometimes at great personal cost, by members of various foreign Communist parties. This official recognition of the crimes of Stalin dealt a severe blow to foreign party membership. ${ }^{29}$ Lastly, as would be characteristic of other attempts at rehabilitating Party legacy, this process of reform was accompanied by a wave of different repressions. Eight months after Khrushchev made the famous speech, he sent tanks to brutally suppress the Hungarian Revolution. ${ }^{30}$ For all the rhetoric of reform, Khrushchev and the new Party leadership were prepared to use the police and military to enforce their power.

The speech, which took over four hours to deliver, criticized Stalin sharply, describing him as rude, conceited, indecisive, a poor war-time commander, ${ }^{31}$ "a very

\footnotetext{
${ }^{29}$ For the reaction to the 'secret speech' of a long time American Communist see Joseph Strabodin "1956 A Memoir" (1966) Problems of Communism, Vol. 15 in Suny, Ronald G. eds., The Structure of Soviet History: Essays and Documents. (New York and Oxford: Oxford University Press, 2003.)

${ }^{30}$ The Hungarian Revolution began as a grass-roots movement against Stalinist policies on October 23rd, 1956. At first the revolt was successful, a new government was formed and the state security police were disbanded. Free elections were scheduled and Hungary announced its intention to leave the Warsaw Pact. The Politburo initially agreed to negotiate a withdrawal of Soviet troops but in early November a large military force entered various points in Hungary killing over two thousand people. By the New Year a Soviet-backed government was installed and had successfully eliminated almost all opposition.

${ }^{31}$ Khrushchev detailed one incident when he called Stalin from the front line in order to ask him to change the plans for the defence of the Kharkov region. Stalin refused to change the plans even though the Red
} 
distrustful man, sickly suspicious. ${ }^{, 32}$ However, beyond these personalized attacks against Stalin, acknowledgement of the scope and criminality of repressions were limited in three specific ways. First, Khrushchev identified the repressions as beginning in 1934, thereby dismissing the earlier, often violent, measures employed in the collectivization campaign of $1929-1933$. He further admitted that there were internal 'counterrevolutionary' elements within the Party prior to 1929 , the fight against which was justified on 'ideological grounds.' The repression of Trotskyites was therefore deemed to be politically necessary. Second, Khrushchev identified 'many thousands of people,' chiefly Party cadres and military personnel, as the primary victims of Stalin's purges. Not only was the number of victims a huge underestimate, but no ordinary Soviet citizens, peasants, factory workers, or other professionals were ever mentioned. Instead, Khrushchev illustrated the plight of victims by reading from letters written by jailed Party members pleading their innocence and devotion to the Party. He spoke at length about the arbitrariness of the arrests and the use of falsified evidence to convict those detained. Finally, Khrushchev limited potential criticism by ascribing the blame for repressions to Stalin, 'Beria's gang,' and a few other officials who had already been punished and expelled from the Party by the time of the speech. The Party as whole was almost completely exonerated.

"As facts prove, Stalin, using his unlimited power, allowed himself many abuses, acting in the name of the Central Committee, not asking for the opinion of the Committee members nor even of the opinions of the Central Committee's Politburo; often he did not inform them about his personal decisions concerning very important Party and government matters.",33

Army had been surrounded by the Germans. Khrushchev pointed out that Stalin planned military operations on a globe, not a map.

${ }^{32}$ Wolfe, supra note 27 at 158.

${ }^{33}$ Ibid at 116. 
With the Party as chief victim, and all the responsible persons punished, Khrushchev insisted "that no surviving Politburo members were guilty."34 Much of the rest of the speech was devoted to the abolishment of the cult of personality, which included, internally, the democratisation of Party decision-making and, externally, cultural deStalinisation.

Public, or cultural, de-Stalinisation, which took place between 1956 and 1964, came to be known as the 'thaw.' This was a period of time when the so-called 'camp' and 'returnee' themes appeared in literature, film, art, ballet, and history textbooks were updated to include the names of people repressed by Stalin. Importantly, the history of WWII underwent a revision which more accurately detailed the role of military commanders and the sacrifices of civilians, downplaying Stalin's self-titled role of 'Generalissimo.' The thaw culminated with the removal of Stalin's body from the Lenin Mausoleum on the night of October $31^{\text {st }}, 1961 .^{35}$ This was a measure which was called for, and passed by resolution, at the Twenty-Second Party Congress held in October of 1961. At that Congress, Khrushchev made another speech this time broadening the category of victims to include 'the Soviet people' and accusing living politicians of "illegal mass repressions." ${ }^{36}$ This was a more radical version of de-Stalinisation and it eventually led to a coup against Khrushchev in 1964. "Within eighteen months of Khrushchev's overthrow, official de-Stalinisation was at an end [and] a pronounced

\footnotetext{
${ }^{34}$ Cohen, supra note 26 at 33 .

${ }^{35}$ Many have identified the state-approved publication of Alexandr Solzhenitsyn's One Day in the Life of Ivan Denisovich in 1962 as the high point of Khrushchev's thaw. Just twelve years later, after winning the Nobel Prize for Literature, Solzhenitsyn was arrested and expelled from the country.

${ }^{36}$ Cohen, supra note 26 at 37.
} 
reverse pattern had developed. ${ }^{37}$ Nevertheless, for over a decade, the process of political and legal rehabilitations had gone on.

Before proceeding with a discussion of the description of victims and perpetrators, however, I want to make a few notes about the procedures of rehabilitation which, like the definition of rehabilitation, are not described in Reabilitatsia and were never set out in legislation. Rehabilitations during the Khrushchev era cannot be described accurately as random. Yet neither were they systematic or regulated through set procedure. Most rehabilitations were done by a travelling three person commission, consisting of an official from the prosecutor's office, a Party representative and a member of the Party that had already been rehabilitated. ${ }^{38}$ The commissions would review individual files, conduct a brief interview and pardon or rehabilitate an individual on the spot. The process of rehabilitation thus mirrored the process of conviction: a brief interview before a verdict passed by an extrajudicial body. And much like convictions of the Stalin era, rehabilitation decisions were not subject to appeal. The criteria for rehabilitation has never been fully explained, and it would seem that there was never a centrally dictated set of qualities, conditions, or characteristics to guide the examiners in granting or denying requests for rehabilitation. Each committee set its own guidelines. As a result of this arbitrariness, complicated cases were often refused rehabilitation because the political or ideological issues at stake could not be sorted out. ${ }^{39}$ Furthermore, because the process was never demystified, many victims were hesitant to apply for a review of their case and fearful of the official result. Kathleen Smith details returnees' reaction to

\footnotetext{
${ }^{37}$ Cohen, supra note 26 at 43.

${ }^{38}$ Kathleen E. Smith. Remembering Stalin's Victims: Popular Memory and the End of the USSR. (Ithaca and London: Cornell University Press, 1996) at 133.

${ }^{39}$ Ibid at 135 .
} 
being called to get their rehabilitation documents: “[M]any people apparently misinterpreted the summons as the start of a new prison term, and showed up wearing layers of warm clothing, equipped with food packages, and accompanied by weeping relatives. ${ }^{40}$ It seems that people both prepared for, and expected, capricious detention and arrest.

\section{Early Rehabilitations}

The third part of Reabilitatsia, entitled 'How the Process of Rehabilitations Began,' lists cases of rehabilitated individuals and those expelled from the Party for illegal activities during two review processes, the first lasting from 1953 to 1956, and the second lasting from 1959 to 1961 . I argue that the rehabilitations and punishments included in this part of the report point to specific change in Soviet policy through the appropriation of the stories of 'honourable' victims and rejection of arbitrary and malicious prosecutions. Both were ways to alter the image of the Communist Party and further distance it from Stalinism.

The victims included in this first wave of rehabilitations largely fell into one of two groups based on their occupations. The first group consisted of those persecuted as a result of military involvement, whether army officers or civilians who were punished for surrendering to the enemy or for remaining on enemy occupied territory. Most soldiers were described in the same manner:

"Comrade Lieutenant-General I. A. Laskin, a member of the Party since 1920, was surrounded while trying to make his way to the front and was detained by the Germans in August of 1941; he subsequently escaped. He then commanded the $172^{\text {nd }}$, took part in the defence of Sevastopol, was injured and, from August 1942 onward, commanded the $64^{\text {th }}$ in Stalingrad. On December $18^{\text {th }}, 1943$...Laskin was summoned to Moscow and charged with 'connection

\footnotetext{
${ }^{40}$ Smith, supra note 38 at 138.
} 
to enemy intelligence agents.' Laskin was held for eight years without trial. In June of 1952, a military tribunal began a new investigation into his case. In order to end his illegal detention, the tribunal came to the following conclusion: Laskin was guilty of 'violating military standards of conduct' because, in the presence of the enemy, he had destroyed a Party document, abandoned his weapon and dressed in civilian clothing. On this charge he was sentenced to ten years of incarceration...At present, [Laskin] has been rehabilitated and re-instated into the Party., 41

The second group of rehabilitated victims included in this section of Reabilitatsia were Party members of various ranks, purged between 1934 and 1950. Within this group I also include individuals who were not members of the executive of any Party organization but were notable because of their connection to, or involvement with, the Bolshevik Revolution. Those associated with Lenin, like N. A. Ehmelyanov, a member of the Party since 1904, who "in 1906 transported Party literature and weapons for the armed wing of the Russian Socialist-Democratic Worker's Party [and] in August of 1917, on orders from the Party, hid V. I. Lenin in his home, ${ }^{, 42}$ were especially listed to depict the unfairness of repressions. The Politburo authors of the report made clear that loyal Communists were subjected to unmerited and capricious repressions despite admirable service in the Party since the Revolution. This point was further stressed by the listing of various contributions made by the rehabilitated individuals to the development of socialism since their re-instatement. "The overwhelming majority of those restored have once again become heavily involved in socio-political and labour-oriented activities. Some have even been elected to Party councils. ${ }^{, 43}$ Thus constant and unwavering allegiance to the Party is a prominent theme in the characterization of victims and

\footnotetext{
${ }^{41}$ Reabilitatsia, supra note 4 at $70-71$.

${ }^{42}$ Ibid at 68.

${ }^{43}$ Ibid at 75 .
} 
suggests a reclamation, by Khrushchev, of the 'original' spirit of the Revolution tarnished by Stalin's conduct.

This alignment of Khrushchev's Communist Party with the plight of valiant victims of repression is one part of the two-pronged narrative of Party reform. In contrast Stalin's leadership, which authorized unfair, arbitrary, excessive and unjust prosecutions, Khrushchev's leadership is characterized as both reasonable and moderate. During the terror and post-war years, many Party members were routinely accused of being involved in various counterrevolutionary and bourgeois organizations or groups. These groups were completely fictitious and were usually created by NKVD officers in order to implicate those Party members selected for repression. Confessions were extracted through torture and evidence was widely fabricated. In these cases, no actual crime or guilty act had to be committed in order to ensure a conviction for counterrevolutionary activities. $^{44}$ In opposition to the conduct of those responsible for repressions, the process of rehabilitations is described time and again as fair, individual, balanced, and impartial. Physical coercion is denounced as a violation of Leninist principles. The role of the security services like the NKVD and OGPU is minimized to signal that "violent purge of political opponents [is] no longer characteristic of Soviet politics, and the violent political

\footnotetext{
${ }^{44}$ Confessions were usually obtained through false evidence or outright torture. There is, however, one case listed in the Politburo report, which seems to be an extraordinary example of entrapment. In 1941, NKVD agents in the Habarov region built a fake border crossing with Japan, some fifty kilometres from the city of Habarovsk, in order to induce people into committing treason. The NKVD selected people suspected of anti-Soviet activity and recruited them to carry out 'special missions' in Japan. These individuals crossed the fake border and were promptly captured by NKVD officers posing as Japanese soldiers. They were then beaten, forced to confess their missions, and convinced to become double-agents. Upon being sent back across the fake border they were again captured by the NKVD, forced to confess being double-agents and shipped to prison. In total, this was done to 148 individuals; all received lengthy prison terms of no less than twenty years. For this elaborate scheme, the Control Party Commission expelled 68 NKVD officers for "violations of revolutionary law" (Reabilitatsia, supra note 4 at 75). It is unclear whether any of them were criminally prosecuted.
} 
purges of the past [are] no longer to be condoned, either." ${ }^{, 45}$ Furthermore, the mass review of applications, which allowed for the en masse refusal of appeals and was the norm during Stalin's life, is rejected in favour of a more systematic and comprehensive review process. Thus, unlike the earlier Stalin-era procedures, the process of rehabilitation during the 1950 s and early 60 s was done in a "strongly individualistic and scrupulous manner," ${ }^{46}$ exemplifying the reformed nature of the Communist Party under Khrushchev. I must note here that these claims of procedural fairness have been undercut recently by the accounts of former bureaucrats who were involved in rehabilitation commissions. As mentioned above, no clear guidelines for how and who to rehabilitate were ever set. Therefore, while the process of rehabilitations under Khrushchev was perhaps less cruelly random, it was by no means 'just'; regardless of factual innocence, some individuals were rehabilitated, and others were not. Documents contained in Reabilitatsia, which date from 1961, when the substantial part of the early rehabilitation process was coming to an end, list 700, 000 people as rehabilitated. ${ }^{47}$ This, however, was but a fraction of the 3 , 778, 234 people who were "unjustly sentenced" between 1930 and $1953 .{ }^{48}$

As mentioned above, Khrushchev began a second wave of stronger deStalinisation after the Twenty-Second Party Congress in which he directly named living, and prominent, Party members as responsible for the repressions. His actions eventually led to his removal as General Secretary and the election of Leonid Brezhnev. Khrushchev's thaw became Brezhnev's stagnation. It would be another twenty years

\footnotetext{
${ }^{45}$ Shapiro, "Rehabilitation Policy under the Post-Khrushchev Leadership" supra note 9 at 492.

${ }^{46}$ Reabilitatsia, supra note 4 at 88.

${ }^{47}$ Ibid at 90.

${ }^{48}$ This is a figure issued by the Moscow KGB in 1990 and cited by Smith, supra note 38 at 8 .
} 
before questions of accountability and memory, and therefore rehabilitation, surfaced again.

\section{Memorial and Memory}

In the 1980s, as with Khrushchev's rehabilitations, the impetuous for examining past abuses came both from below and from above. Gorbachev's reforms promoted policies of accountability and feedback and also allowed for the re-emergence and tolerance of criticism due in large part to a policy of 'socialist pluralism.' "Socialist pluralism differed from permitted dissent in allowing self-constructed social groups to express their special interests...[it], however, bore little resemblance to a 'public sphere'...Gorbachev did not intend to put the people in a position to judge or protest his policies. ${ }^{, 49}$ Moreover, the entire process had an air of uncertainty both for the state and for emerging social organizations. How much criticism would be tolerated? Could liberalization be revered? What did 'reformed' Communism look like?

New state policies allowed, in theory, for independent organizations to form, but there was no official registration system in place to make them legal. Thus, new clubs and groups gained the title 'nerformaly', or informals. ${ }^{50}$ This was partly because they had no association with the state, no official registration of membership or agenda, but also because they did not legally 'exist' and could not, therefore, open bank accounts, sign contracts or rent spaces. Nevertheless, many of these groups began to form, and were largely tolerated by the state, in 1986 . The groups varied in size and agenda. Some

\footnotetext{
${ }^{49}$ Smith, supra note 38 at $78-79$.

${ }^{50}$ For a detailed discussion see, Vyacheslav Igrunov, "Public Movements: From Protest to Political SelfConsciousness" in After Perestroika: Democracy in the Soviet Union. Brad Roberts and Nina Belyaeva eds., (Washington, D.C.: CSIS, 1991).
} 
focussed on the environment, family values, rock music, art, socialist theory, and even more 'radical' subjects like democratization. One such club, Klub Perestroika, which was made up of students from the Central Econometrics Institute, recently returned political prisoners, various academics, and participants in national movements, took up the cause of erecting a monument to the victims of Stalinist repression in June of 1987.

The campaign for a monument was led by a thirty-five year old geologist, named Iurii Samodurov, whose grandmother had survived a labour camp. His proposal was quite small and generally respectful to the authorities. He offered no criticism of the present regime, and only minimal mention of any past perpetrators. By August of 1987, Samodurov got the attention of the Moscow City Committee and held a joint public forum with them in order to raise funds for the proposed monument. At this meeting, however, Samodurov and others, called for the broadening of the category of victims to include all repressed individuals. These comments "caused no small panic among the Party apparatchiks...Here was this anti-Soviet organization that had spoken out against the repressions of Leninist times, not just Stalinist times." ${ }^{\text {51 }}$ The monument proposal was quickly voted down by Party officials. From this meeting, a group calling itself 'To Keep Alive the Memory of Victims of Repression,' later renamed Memorial, emerged. At its official inception, on October $7^{\text {th }}, 1987$, the group had exactly eleven members. ${ }^{52}$ Memorial's approach to public recognition and support was moderate and steady in comparison with some of the other political groups calling for de-Stalinisation active at

\footnotetext{
${ }^{51}$ Smith, supra note 38 at 83-84.

${ }_{52}$ Iurii Samodurov (geologist), Lev Ponomarev (doctor of physics), Pavel Kudiukin (historian), Iurii Skubko (economist), Victor Kuzin (lawyer), Dmitrii Leonov (eceonomist), Mikhail Kovalenko (lawyer), Aleksei Zverev (translator), Gennadii Demin (theatre director), Dmitrii Iurasov (historian), and Evgenii Krasinkov. Notably, there are no rehabilitated or non-rehabilitated victims in the original membership. Many survivors would later join, but because the group received no press coverage, at the beginning it was made up of about a dozen young academics and professionals.
} 
the time. They neither openly criticized Gorbachev, or even Stalin, nor did they call for an end to socialism. Yet the group's efforts were blocked repeatedly through judicial injunction, KGB intervention, and even workplace reprimand. When Memorial members tried to ask for Party co-operation in efforts to commemorate victims, they were advised that the proper place for political agitation was in the trade unions or the Komsomol. ${ }^{53}$ At a meeting with the Propaganda Department of the Moscow Party organization, Memorial was told that plans for a monument had already been made by the Ministry of Culture. It would be erected in 2010 . Undaunted, the group continued its work independently and in 1989 erected a small monument to the victims of repression placed facing the statue of 'Iron' Feliks Dzerzhinskii, founder of the Soviet secret police, at Lubyanka Square in Moscow.

I have described the history of Memorial because its early campaigns for remembrance demonstrate that while perestroika may have opened the door for greater public participation, it in no way was meant to spell the beginning of a public sphere in Russia. The Communist Party was always meant to remain the guiding force in society and so independent initiative for remembrance and reform could not be allowed to overtake Party policy. Yet despite attempts at subduing calls for remembrance, the state eventually had no choice but to get involved in the process of 'filling in' the gaps in Soviet history. "Spontaneous and uncoordinated media reports about the past atrocities led officials to search for a means to reassert control over the revelations about the purges without revising glasnost....Significantly, investigation of repressions remained the

\footnotetext{
${ }^{53}$ Smith, supra note 38 at 88.
} 
province of the Party, not the government or an independent committee." ${ }^{, 54}$ The desire for more substantial change was thereby both co-opted and rechanneled by the Party in order to diminish any threat it might have posed to the Soviet system. The preface to Reabilitatsia, written in 1989, speaks to this effort and to the tension between a careful retelling of the Soviet past, promoting a narrative of Party-led reform, and an emphasis on the continuity of the Soviet system. In retrospect, this narrative is made somewhat ironic given that only a year after the publication of Reabilitatsia, the Soviet system would cease to be, having succumb to the wave of reform it tried so hard to guide. Nevertheless, this incomplete retelling of Soviet history and rehabilitation of its victims remains the 'official' attempt by the state. Reabilitatsia is therefore suggestive of the unfinished process of transition from dictatorship to democracy in Russia, a process made imperfect by a lack of real political justice that resulted from the limited narrative of rehabilitation. Below, I explore the preface of Reabilitatsia and the mandate of the Politburo Commission included therein. I then proceed to the discussion of victims focussing on one of the eleven cases of rehabilitation discussed in detail in section four of Reabilitatsia, 'Falsified Processes: History and the Present.'

\section{Linking Rehabilitation and Reform}

The introduction of Reabilitatsia, written by Academician and Doctor of Philosophy N. Mikhaelov, pays homage to the spirit of perestroika and the widespread desire for a "truthful examination of the past." 55 This state officiated inspection of the past is vital because, as the reader is informed by Gorbachev himself, "of the importance of those years for the fate of our government, the fate of our socialism...especially now as

\footnotetext{
${ }^{54}$ Smith, supra note 38 at 141.

${ }^{55}$ Reabilitatsia, supra note 4 at 5 .
} 
perestroika proceeds; we need this not to settle political scores or to worry individual consciences, but in order to give credit to the heroism of the past and to gain a lesson from past mistakes and misdeeds. ${ }^{, 56}$ I contend that two things are immediately clear from these preliminary remarks: first, 'those years' refer to Stalin-era repressions beginning in the 1930s and ending in the early 1950s, no other repressions are to be discussed, and second, no individuals need to worry about punishment for misdeeds which may be uncovered by the Politburo. This document is therefore presented as a kind of historical reference for those interested in the 'tragic events of the past.' The Politburo neither purports to judge individual culpability or to broaden the scope of analysis to cover repressions beyond Stalin's reign. These conclusions about Stalin's guilt are similar to those made during Khrushchev's time. "All levels of society, all professions, nationalities, and faiths, throughout the country...somehow affected by the hammer of Stalin's repressions.. ${ }^{, 57}$ And although I argue that, overall, this report fails to facilitate political transformation because it does not judge the past sufficiently, some interesting conclusions about the nature of the regime are nevertheless reached in parts of the introduction. As such, I want to begin the discussion of the last wave of rehabilitations by noting these telling, though couched, admissions.

First and foremost, the introduction written by Mikhaelov acknowledges that the Soviet regime was inherently violent. He states that after the Bolshevik Revolution the use of force "became its [the Soviet government's] most important function. This was directed by the continued resistance of the overthrown oppressing classes and the

\footnotetext{
${ }^{56}$ Reabilitatsia, supra note 4 at 5.

${ }^{57}$ Ibid at 9.
} 
fierceness of political battle. ${ }^{, 58}$ Thus, violence was not limited to fighting political battles, but was also employed as a motivating factor in labour and production "because a worker did not (could not) expect any financial, economic or social reward resulting from increased production under the regime of military-style Communism." ${ }^{, 59}$ This is an extremely important revelation about the nature of the Soviet regime. Violence was always at the heart of the Soviet state, and was built into its very foundation. Yet this admission also acts to obscure a further point. Although violence may have always been part of Soviet governance, there is no mention in either the introduction or the rest of the report of Lenin's repressions. Instead, the well established assertion, made from the time of Khrushchev, that Stalin instituted unheard of methods of terror in the Soviet Union, is repeated. In actuality, both before and after the Revolution, Lenin authorized the use of force against civilian populations whether or not they were involved in a struggle against the Bolsheviks. In A Century of Violence in Soviet Russia, the last book written before his death, Yakovlev, the former head of the Politburo Commission, describes Lenin as an "exponent of mass terror, violence, the dictatorship of the proletariat, class struggle and other inhuman concepts...Incessant in his demands for arrests and capital punishment by bullet or rope. Personally responsible for the deaths of millions of Russian citizens." 60 Interestingly, Yakovlev used archival documents that he gained access to as part of the Commission's work to illustrate that "in his punitive operations Stalin did not think up anything that was not there under Lenin: executions, hostage taking, concentration camps, and all the rest." ${ }^{\prime 61}$ Lenin famously called for the mobilization of 'energy and mass

\footnotetext{
${ }^{58}$ Reabilitatsia, supra note 4 at 13.

${ }^{59} \mathrm{Tbid}$.

${ }^{60}$ Yakovlev, supra note 2 at 15.

${ }^{61}$ Ibid at 20.
} 
terror' against counterrevolutionaries. It is clear then, that while Stalin broadened the scope of terror, he was by no means the originator of it. Despite this, official documents produced by both the Soviet and Russian government continue to characterize Lenin's repressions as 'necessary' in the context of a Revolutionary struggle. In the end, this important but brief mention about the origins of repressive measures and the generally accepted use of violence by the Soviet state is overshadowed by the Commission's general refusal to engage in a discussion of culpability for anyone other than Stalin or his associates. Limited culpability would become a common theme during Russia's transitional period. A year after Reabilitatsia was published, Russia's Constitutional Court would deliver a judgment on the Communist Party equally limited in scope. This decision is the subject of the next chapter. It will suffice to say here that, individuals, not a violent, authoritarian, arbitrary and cruel system, were responsible for repressions, remains the pervasive opinion in Russia society today.

The mandate for the new wave of rehabilitations, contained within a Politburo decree dated January $5^{\text {th }}, 1989$, follows the introduction of Reabilitatsia. It reads: "The restoration of historical and legal justness has now acquired great political significance. The development of a just socialist government and the expansion of the collective consciousness of society depend on their restoration. Victims, families, and society as a whole await the rehabilitation of all those repressed and the restoration of their reputations. ${ }^{, 62}$ To this end, the Politburo issued two directives in July and October of 1988 that aimed to streamline the process of rehabilitation. The first ordered local KGB offices to undertake a review of cases from 1930 to 1953 "independent of individual

\footnotetext{
${ }^{62}$ Reabilitatsia, supra note 4 at 17, from 'On Further Measures to Restore the Honourable Reputation of Victims of Repression' decree of January $5^{\text {th }}, 1989$.
} 
complaints. ${ }^{, 63}$ The cases recommended for rehabilitation would be submitted to the Office of the Prosecutor who then prepared them for review by the Supreme Court. The second directive was more sweeping; it annulled sentences passed as a result of hearings conducted by 'troikas' or 'special tribunals.' These were usually a three-person extrajudicial committee set up to hear cases of counterrevolutionary activities; the committees did not allow for defence council or the right of appeal. The Politburo decree described these commissions as "the pinnacle of arbitrary and lawless rule" 64 and directed the Presidium of the High Council of the USSR to pass legislation that would void them. ${ }^{65}$

Several things are noteworthy about these decrees and the initial mandate. First, they were issued immediately after the first sanctioned meeting of Memorial and around the same time that university entrance exams in history were cancelled ${ }^{66}$ Between 1988 and 1991, Russian historiography was undergoing a continual revision that state policy tried to limit and stay ahead of. Second, although the decrees facilitated the rehabilitation of almost a million people in less than two years, they failed to satisfy growing demands for a more comprehensive definition of victim. Victims of collectivization, those prosecuted for religious beliefs, or more recent dissidents of the 1970s and 1980s continued to fight for inclusion in the rehabilitation process. As a result, in 1990,

\footnotetext{
${ }^{63}$ Reabilitatsia, supra note 4 at 17, from 'On Additional Work to be Conducted in the Rehabilitation of People Unjustly Repressed during the 1930 s, 40 s, and 50s.'

${ }^{65}$ This directive of the Politburo highlights the issue of 'party hegemony' which will be discussed in greater detail in the next chapter in the CPSU trial. The open and frank way in which a Party organization could direct both a legislative and judicial body to carry out certain actions demonstrates the extent to which the Communist Party controlled all aspects of the state. The CPSU's later arguments, made in the spring of 1992, that it was a mere political party are plainly contradicted by these directives.

${ }^{66}$ The decision to cancel exams was due to "the recognition that it was no longer possible to deny the 'lies contained in the historical texts." See, James V. Wertsch "Revisiting Russian History" (1999) Written Communication, Vol.16 (3) at 267.
} 
Gorbachev ordered the restoration of rights for those who suffered in forced collectivization campaigns or were classified as 'eliminated as a class.' He also restored the citizenship of twenty-two dissidents that had been exiled abroad under Brezhnev. ${ }^{67}$ He declined, however, to acknowledge that human rights violations had been systematic and that repressions were not limited to any one especially regrettable period in Soviet history. Gorbachev's, and the Soviet government's, stance on the scope of repressions guided the Politburo's work limiting the 'kinds' of victims included in Reabilitatsia. Before proceeding with a more detailed exploration of some of the victims included in the report, I want to first discuss the constructed and constructive qualities of the notion of victimhood.

Victimhood is a concept that is often conceived of as having rigid contours which enable immediate identification of individuals as belonging within or without the group. Although convenient, this image of victimhood relies on a specific and static understanding of 'crime' and 'innocence' and is, for this reason, idealized. In reality, the boundaries of victimhood are permeable, uncertain, time and context dependent, and even reversible. Various factors influence inclusion and exclusion of certain individuals within the category of victims, not least of which is who or what controls the process of identification. Because of the way political transformation was allowed to unfolded, I focus here on state identification of the condition of victimhood. This top-down process, which in the USSR was done in the context of political revitalization, is important because it illustrates specific state goals. I argue that by recognizing victims of particular past injustices, namely Stalin era repressions, and then incorporating their stories of

\footnotetext{
${ }^{67}$ Smith, supra note 38 at 143.
} 
suffering into a national narrative of reform, the Communist Party accomplished a rehabilitation of its own past. This rehabilitation, as already mentioned, was meant to facilitate a program of state reform and had acquired, as is stated in the mandate for the Politburo commission, 'great political significance.' Given its importance, not only did the state dictate the conditions of victimhood, but it also pre-empted independent and publically driven calls for compensation and rehabilitation, thereby ensuring a controlled process of political alteration rather than an uncontrolled political transformation. Victims, as they appear in Reabilitatsia, are reduced to pieces of a state driven narrative in which "[t]he contested past is reordered and resignified to enable and to legitimize visions of desirable future. ${ }^{, 68}$ My aim in examining the way victims are described in Reabilitatsia is to highlight this state created 'vision of a desirable future.' I argue that this future was never conceived of as being guided by any political force other than the Communist Party, the examination of the past was therefore not complete and not conducive to a full process of political justice. True rehabilitation was reserved for the Communist Party.

For the purposes of clarity of argument, I focus my comments on two different groups of victims included in Reabilitatsia: exemplary and passive. Both categories were persecuted on 'political' grounds, meaning they were victimized by a general political policy like collectivization, or they were purged to meet some centrally set quota, but one group is revived and discussed in detail while the other is described only as a set of statistics. And although the statistics made up of passive victims also speak to some interesting political trends of the late 1980s and early 1990s, the discussion of exemplary

\footnotetext{
${ }^{68}$ Christiane Wilke. "Recognizing Victimhood: Politics and Narratives of Rehabilitation in Germany" (2007) Journal of Human Rights, Vol. 6 (4) at 483.
} 
victims illustrates much more clearly the kind of political revitalization that the Communist Party was looking for. These cases, of which there are eleven in the report, are examples of a shift in state policy and the application of socialist legality.

The mention of ordinary victims, those I term passive victims because of the way they were portrayed in Reabilitatsia, is limited. In the last section of the report, 'On the Progress of Completing the Process of Rehabilitations of Individuals Unjustly Repressed in the 1930s, 1940s, and 1950s, as Decreed by the CC CPSU on 11 July 1988 and 5 January 1989,' the Politburo states that from January of 1989 to January of 1990 a total of 807,288 individuals convicted by special tribunals were judicially rehabilitated. A further thirty thousand individuals convicted by normal courts were also judicially rehabilitated; ninety percent of these rehabilitations were done posthumously. ${ }^{69}$ Interestingly, unlike the earlier processes of rehabilitation, only ten thousand people asked for Party membership, just over ten percent of living rehabilitated victims. This statistic is symptomatic of a change in the value of Party membership within society. In the late 1980s and early 1990s, membership in the Communist Party was no longer essential, many people, therefore, never entered the Party and few asked to be re-instated into its ranks.

Moreover, very few individuals from the passive category of victims are actually named by the Politburo in the second wave of rehabilitations. This is in sharp contrast to the Khrushchev era rehabilitations, which provided for brief biographies of the victims. In total, the 1990 summary names nine rehabilitated victims. The only personal information provided on these victims comes in the form of brief quotations from their

\footnotetext{
${ }^{69}$ Reabilitatsia, supra note 4 at 328.
} 
letters written asking for rehabilitation. Notably, all the letters cited "voice their support for perestroika and [...] ask for a 'final verdict on Stalin's actions",70 Passive victims are therefore only heard in order to legitimate Gorbachev's government and promote the policy of assigning culpability solely to Stalin.

Both passive and exemplary victims serve a particular purpose. What separates the two categories is not their potential for utilization by the state. On the contrary, I argue that all victims are in the end utilized in the narrative of reform. Instead, I propose that what separates the passive victims from exemplary victims is how they are utilized. The cases of exemplary victims offer a way of reclaiming certain principles seen as tarnished during the Stalin and Brezhnev eras and subsequently resurrected by perestroika. People like Bukharin, and the example I examine here, M. N. Ryutin, became martyrs, persecuted under an unfair regime. Thus the plight of these exemplary victims serves a dual purpose. It both highlights principles reclaimed by a reformed Communist Party and makes evident that the real victims of repression were always members of the CPSU.

Martemyan Nikitich Ryutin was part of the larger Bukharin - Rykov opposition, and his case is known sometimes as the 'Ryutin Affair' but referred to in Reabilitatsia as the case of the 'Marx-Lenin Union of 1932.' His was one of the last attempts to oppose Stalin's leadership of the Communist Party by leading Bolsheviks. While Ryutin's opposition to Stalin was real, in contrast to the many completely fabricated cases that would be charged against other Party members in the years after this case, the accusations against him were at best exaggerated and at worst completely false. Furthermore, his

\footnotetext{
${ }^{70}$ Reabilitatsia, supra note 4 at 331.
} 
arrest, detention, trial and retrial demonstrate some of the common practices of the NKVD used against many repressed individuals: falsified documents, physical coercion used to obtain confessions, and an extrajudicial process without the right to defence council or the right of appeal. Given this, the process of repressing Ryutin was not quite unique in the context of the purges. What sparked his repression, however, sets his case apart from the ones that would follow. Ryutin's opposition to Stalin, besides being 'real,' was ideologically and politically informed; he criticized the dictator for a failed and brutal process of collectivization and for severely curtailing Party democracy, thereby violating the principles of socialism. His active agitation against Stalin, which came in the form of letters and petitions distributed to Party members, eventually led to his dismissal from the Party and arrest. Out of the millions of people who would later be accused of participating in Bukharinist plots and various 'rightist' groups, Ryutin is one of the few to have ever actually offered criticism of Stalin's regime. This, of course, does not diminish the fact that his political dissidence was prosecuted as a form of terrorism, but it makes his case stand apart from the many others.

Ryutin joined the Party in 1914; after the Revolution he became a teacher and organizer working to "establish Soviet power in the far east." ${ }^{\text {71 }}$ He eventually became secretary to the Moscow City Communist Party in 1924. Four years later, he was removed from his post and relieved of all of his Party obligations for making disparaging remarks about Stalin at a meeting. A report from that time quotes Ryutin as saying: "We know that Comrade Stalin has certain shortcomings which were noted by Comrade

\footnotetext{
${ }^{71}$ Reabilitatsia, supra note 4 at 98.
} 
Lenin." "72 This comment is described as 'inexcusable' because it "too closely mirror[ed] the position of Trotskyites." ${ }^{\text {73 }}$ After being dismissed from the Moscow City Communist Party, Ryutin was made editor of the Red Star Newspaper. In 1929 Ryutin was sent on assignment to check on the process of collectivization in Eastern Siberia. Reabilitatsia notes:

"There he was confronted with crude violations of Lenin's philosophy, cases of physical coercion and abuse, as well as deaths attributed to the construction of collective farms. On his return to Moscow, Ryutin wrote a note to the Politburo detailing his experiences on the collective farm and raising questions about the entire system of collectivization; this note provoked the ire of both Stalin and Kaganov."74

It seems that Ryutin's outrage over collectivization, evidence of which is not documented in Reabilitatsia, and his comments about Stalin made him the target of investigation by 1930. In October of 1931 Ryutin was arrested by the NKVD but released due to a lack of evidence. The reason for his arrest six months later is the subject of some controversy. In March of 1932, Ryutin and some other members of the Party prepared two documents: 'Stalin and the Crisis Facing the Dictatorship of the Proletariat' and 'Appeal to All Members of the All-Union Communist Party.' The two documents contained a "bleak forecast about the economic situation which was in large part due to Stalin's campaign of industry development and mass forced collectivization. The platform proposed a democratization of inter-Party decision-making, a return to Leninist Party norms...and a revisiting of the forced re-settlement programs.,"75 These documents were distributed throughout the Party. Although parts of the 'Appeal' are reproduced in Reabilitatsia, it is unclear whether or not it was the same copy originally written by

\footnotetext{
${ }^{72}$ Reabilitatsia, supra note 4 at 99.

${ }^{73}$ Ibid at 98 .

${ }^{74}$ Ibid at 100 .

${ }^{75}$ Ibid at 93.
} 
Ryutin. While in custody, Ryutin admitted writing a document with that title but claimed that the NKVD has subsequently added some especially inflammatory remarks. This seems plausible since during his prosecution Ryutin was depicted as a terrorist and counterrevolutionary who called for the rebuilding of a bourgeois economy within Russia, allegations which did not correspond with Ryutin's earlier conduct or ideological publications. Ryutin's unwavering belief in the Soviet system, his 'exemplary' status, is highlighted throughout the description of his case.

"Even those passages in the document which seemed to be more controversial had a tone of discussion and never called for an overthrow of the government, terror or even diminishment of Soviet power. It is obvious that these views differed from those promoted by official propaganda, but they did not depart from the Marx-Leninist consensus about the superiority of socialism [emphasis added]."76

This 'pure' ideology and Ryutin's opposition to Stalin's dictatorship made him a perfect candidate for martyrdom in the late 1980s. The fact that Ryutin was sentenced twice on the same charges made his case even more compelling.

In 1932, he was sentenced to ten years of imprisonment, but four years later

Ryutin was transferred from a labour camp back to Moscow, and charged again. His case files include a letter written on November $4^{\text {th }}, 1936$ in which Ryutin makes a direct appeal to Stalin. It reads in part:

"I do not admit guilt in anything...I am not, and have never been, a terrorist...I have already served five years of a sentence handed down to me for writing these documents...Charging me with the consequences of distributing these documents, a crime for which I am already serving a sentence, is clearly illegal...There is no evidence in my actions, my documents, or the consequences of distributing those documents, of any terrorism. These charges of terrorism are therefore completely fictional...My sentence and conviction have not been nullified. These new charges, based on the same actions, are completely illegal...I am fully coherent and not afraid of death, if

\footnotetext{
${ }^{76}$ Reabilitatsia, supra note 4 at 97.
} 
that is what the NKVD is preparing for me. I want to declare that I am not asking for forgiveness or leniency for crimes that I have not committed."

Since no response was ever received from Stalin or the Politburo, the case against Ryutin proceeded and was eventually heard by a troika on January $10^{\text {th }}, 1937$ without the presence of the accused. Ryutin was sentenced to punishment in the first category, death, and was shot on the same day. On June $8^{\text {th }}, 1988$ the Criminal Affairs Division of the Supreme Court of the USSR reversed Ryutin's original 1932 conviction and five days later the Plenum of the Supreme Court reversed all the convictions passed in connection to the 'Marx-Leninist Union' citing a lack of evidence of criminal activity. In December of the same year, Ryutin was formally rehabilitated and re-instated into the Communist Party.

From this description one can see how Ryutin is an 'exemplary' victim. His redacted story fits the greater narrative of perestroika. His rejection of the allegations made on the basis of principles of the rule of law and his refusal to admit fault or guilt also make him an appealing morally upright victim of repression. This characteristic, combined with the firmness of his belief in the principles of socialism proscribed by Marx and Lenin, add to his general usefulness as a beacon of political revitalization within the Soviet system.

Just like the victims who are included in the process of rehabilitation, those who are absent also reveal aspects about the kind of reform underway at the time. Nowhere in the Politburo report is there a mention of a single individual who voiced objections to the Soviet system as a whole. These people, labelled 'anti-Soviet,' are not included in the process of rehabilitation, and therefore not deemed to be victims of unfair repressions.

\footnotetext{
${ }^{77}$ Reabilitatsia, supra note 4 at 103-104.
} 
Their absence reserves the title of victim for true believers, like Ryutin, who were unjustly punished. Yet those who defied the system by refusing to apply for rehabilitation would eventually confront the state's policy of reform. During the 1980s individuals characterized as victims of repression by the state but rejecting the title problematized the entire process of rehabilitation by challenging the validity, moral authority, and political dominance of the Communist Party. These unrehabilitated victims, as well as rehabilitated victims that complained about the level of compensation, point to the problems associated with state policy of limited culpability. They speak to issues of mass guilt and mass victimhood that were avoided during perestroika and after the collapse of the USSR. I conclude this chapter, therefore, by discussing these 'missing pieces' of rehabilitation policy.

\section{Conclusion: The Innocent and the Unrepentant}

My argument in this chapter has been that the process of rehabilitation was limited by the assumption of continued political dominance of the Communist Party and the Soviet regime. A restricted examination of past abuses guided by a political agenda ensured a rehabilitation of the Communist Party through a narrative of carefully selected and described victims. As a result, no judgment of the Soviet system as a whole, a system that facilitated and allowed for repressions both during Stalin's reign as well as before and after it, was made. Without acknowledgement of the inherently violent nature of the Soviet regime or its criminal bureaucracy, the Communist Party was made both victim and victor of history. And yet this process has not gone on unchallenged. Dissident voices point to the need at a re-examination of the practice, policy and goals of rehabilitation. 
In 2001, Memorial chairman Arseny Roginsky, born in a 'camp zone,' addressed the core issue: "only when the communist regime is recognized as criminal will those who were criminalized for opposing it be exonerated." ${ }^{, 78}$ Rehabilitations ignore the complicity of the entire system; for victims of repression "the mark is removed, but the stain remains." ${ }^{, 79}$ Accordingly, there are a small number of victims who have refused to apply for rehabilitation either because they do not want to 'endorse' the system by participating in it, or because they refuse "to think of themselves as 'criminals,' an implication of the label 'rehabilitation." ${ }^{80}$ Others await the Russian government's moral condemnation of the CPSU without which they argue that "rehabilitation takes place in word only, and not in deed." ${ }^{81}$ Still, others have applied for and received rehabilitation, but have challenged the process on other grounds. Some have objected to the term 'restoration of rights' arguing instead that they should be awarded 'new rights' in recognition of the widespread human rights violations under the Soviet system. Others have challenged the level of compensation. Interestingly, complaints about the processes of rehabilitation, unlike the ones connected to its legitimacy, made their way into Reabilitatsia. A letter from M. Berlyand, a war veteran and camp inmate, is quoted in the report: "As a result of the rehabilitations I received forty-four rubles. This is supposed to pay for eight years in a camp and four years of exile. ${ }^{, 82}$ These types of complaints are less potent and less dangerous, and even they have, over the last decade, become unwelcome in Russia. As time passes, it seems less likely that challenges aimed at the

\footnotetext{
${ }^{78}$ Adler, "The Future of the Soviet Past" supra note 5 at 1103.

${ }^{79}$ Memorial archival interviews with zecks, quotes by Adler, Beyond the Soviet System supra note 25 at 179.

${ }^{80}$ Adler, "The Future of the Soviet Past" supra note 5 at 1103.

${ }^{81}$ Ibid at 1109 .

${ }^{82}$ Reabilitatsia, supra note 4 at 330 .
} 
root of repressions will be successful. As Nanci Adler observes, "It is much riskier and more destabilizing for a regime to disinter skeletal memories that are embedded so closely to the foundations on which it still rests. $" 83$ Today, the plight of even the noblest victims is being forgotten as the Soviet system, a victor without victims, is slowly being resurrected.

Apart from being one of the two examples of attempted political justice, the Politburo's report marks a moment of 'non-change' in Russian history. Reabilitatsia was published on the eve of the collapse of the system which it steadily defended. The findings contained within it were reached on the brink of the change that it tried so hard to resist and would eventually be swept away in. A certainly irony, therefore, accompanied the report's wishes for the continued success of socialism. And yet, despite the momentous political upheaval of August of 1991, the Communist Party would never be made to fully account. Just a year after the publication of Reabilitatsia, a judicial proceeding would judge the very legality of the regime. This report and the trial that followed would become markers of a moment of potential, but unrealized, transformation, a moment of 'non-change.' I examine the extraordinary trial of the Communist Party of the Soviet Union in the next chapter.

${ }^{83}$ Adler, "The Future of the Soviet Past" supra note 5 at 1110. 


\section{ChaPTER FOUR}

\section{Judging the Past: The Trial of The CPSU}

"...the last two days of communism were terribly rainy."

On the morning of Monday August $19^{\text {th }}, 1991$ Russians across the country turned on their televisions to find a recording of a symphony orchestra broadcast on every channel. Instead of regular news programs and talk shows, calm classical music played over the airwaves interrupted every hour from six am on by the reading of the Decree of Vice President Yanaev. The Decree stated that Mikhail Gorbachev had taken ill while on vacation and had transferred the responsibilities of the office of President of the USSR to Vice President Gennadii Yanaev. Yanaev, along with seven other top officials, ${ }^{2}$ had formed the State Committee for the State of Emergency (GKChP). The Committee's first resolution declared a six month state of emergency, effective immediately, instituted in order to "secure vital interests of the people and citizens of the Union of Soviet Socialist Republics...to overcome the most acute crisis and prevent chaos, anarchy, and fratricidal civil war." ${ }^{3}$ Under the state of emergency, all administrative and parliamentary organs, as well as the activities of any political party or organization interfering with the 'normalization' of the situation, were suspended. The Ministry of Internal Affairs, the Committee for State Security (KGB), and the Ministry of Defence were authorized to jointly enforce a prohibition on all public marches, rallies and strikes, to patrol a curfew,

\footnotetext{
${ }^{1}$ Anonymous. "Letter from Moscow." in Victoria Bonnell, Ann Cooper, \& Gregory Freidin eds., Russia at the Barricades: Eyewitness Accounts of the August 1991 Coup. (New York and London: M. E. Sharpe, 1994) at 83.

${ }^{2}$ GKChP was made up of Vice President Gennadii Yanaev, KGB head Vladimir Kriuchkov, Defense Minister Dmitrii Yazov, Minister of Internal Affairs Boris Pugo, Prime Minister Valentin Pavlov, First Deputy Chairman of the National Defense Council Oleg Baklanov, Chairman of the Peasant's Union Vasilii Starodubtsev, and President of the USSR Association of State Enterprises and Industrial Groups in Production, Construction, Transportation, and Communications Aleksandr Tiziakov.

${ }^{3}$ As reported in Pravda. (20 August 1991) in Bonnell et al eds., supra note 1 at 38.
} 
to defend those institutions deemed essential for daily life, and "to curb decisively the spread of all destabilizing rumours, actions provoking the violation of the law...and insubordination."4

By mid morning, the recording of an orchestra playing Beethoven was replaced by a ballet performance. For ordinary citizens, the absolute silence of television and radio, along with the sudden disappearance of daily newspapers, was an even more worrying phenomenon than the closing of international borders or the tanks rolling toward downtown Moscow. People telephoned friends and relatives travelling abroad to warn them against returning home; many feared that the army would call a sudden draft or that a wave of arrest of civil servants, reporters and 'liberal' politicians was imminent. Thus, the morning of August the $19^{\text {th }}$ "for a Soviet being...represent[ed] a clear signal that a sharp turn in policy...[was] in the offing." After almost three years of relative media freedom, economic reform, and increasing political plurality, the GKChP announcement seemed to foreshadow a return to repressive rule.

What unfolded during the following three days in August is important for any historical or post-Soviet analysis, as well as any analysis of contemporary Russian politics. After all, the end of the coup started a chain of legal and political manoeuvres that would, in a matter of four months, lead to the end of the USSR. And given their significance, I discuss the events of August and the circumstances that preceded the coup at some length in this chapter. These events are interesting in their own right because they exemplify unhindered political action taken in a moment of political upheaval. But they also serve as a contextual framework - a necessary background - for the examination of

\footnotetext{
${ }^{4}$ Bonnell, supra note 1 at 39 .

${ }^{5}$ Ibid at 147.
} 
the second case of attempted political justice that is the subject of this thesis. The socalled 'trial of the Communist Party of the Soviet Union (CPSU), ${ }^{, 6}$ which was sparked by the events that took place in August and was heard in the Moscow Constitutional Court between May and November of 1992. I argue that this case was an opportunity for a reckoning with the past, a chance at political justice. From the actors, to the setting, to the arguments, this case embodied both a direct clash and indirect entanglement of the old and new regimes. First, among transitional justice mechanisms, this trial was unique. Although it was not a criminal proceeding, and not initiated by the original coup plotters, it was a legal challenge against a new democratic regime, framed in the language of human rights, and brought by representatives of the former regime. Second, the trial represented a direct intersection between new and old legal systems. It took place in a newly created institution of a recently established democracy but was nevertheless staffed by lawyers and judges educated in the old regime with proceedings governed by the now defunct communist laws, namely the 1978 Constitution of the USSR. Lastly, and most crucially in the context of political justice, the arguments made at the trial of the CPSU were an attempt to simultaneously re-write and cement Soviet history. The narratives delivered by each side represented two alternatives for how the previous seventy five years would be remembered and represented in the future. Ultimately, I argue that just as

\footnotetext{
${ }^{6}$ I have adopted the shorthand title of 'trial of the CPSU' throughout. The case is officially known as In the Case of the Verification of the Constitutionality of Edicts of the President of the Russian Federation No. 79 of 23 August 1991 'On the Suspension of the Activity of the Communist Party of the RSFS, 'No. 90 of 25 August 1991 'On the Property of the CPSU and the Communist Party of the RSFSR, 'No. 169 of 6 November 1991 'On the Activity of the CPSU and the CP RSFSR,' as well as of the Verification of the Constitutionality of the CPSU and the CP RSFSR. 'CP RSFSR' stands for Communist Party of the Russian Soviet Federal Socialist Republic. It was the top party organ in the Russian Republic before the official dissolution of the USSR on 31 December 1991 from which point on it became the Russian Communist Party (RCP).
} 
with the findings of the Politburo Commission, the equivocal and compromise judgment ${ }^{7}$ delivered by the Constitutional Court failed to apprehend natality. It neither firmly condemned the Soviet regime, nor did it provide a foundation in which democratic development could take root. Instead, the Court wavered, choosing to condemn select elite echelons of the Communist Party while making no comment on the regime as a whole. This trial, though somewhat overshadowed by the severe economic decline that began in Russia at the end of 1992, is significant because it represents an attempt at 'judging the past.'

The timeline leading up to the trial, with which I begin my discussion below, is also important because it contained moments of pure political action. I contend that people's unprecedented coming together in resistance against the GKChP coup was another moment of natality, different from those moments experienced in the more ordinary fabric of politics. The spontaneity of action, the real possibility of physical harm, and the breakdown of traditional political organization, coalesced to open the gap between past and future discussed in chapter two. I contend that while the trial of the CPSU was an example of political justice missing the opportunity for historical reckoning, the three day stand-off in the center of Moscow was an example of natality apprehended. More so than the report of the Politburo commission or the trial, the events of those three days were a radical rejection of the Soviet system. The rejection was perhaps made even more genuine by virtue of its origin within the gap. It was, however,

\footnotetext{
${ }^{7}$ The arguments of both sides were heavily reported on in the media but were summarized only partially in the final judgment, or 'decree,' of the Constitutional Court. Therefore, while I use the official court judgment as much as possible, I have had to rely on media reports, journal articles and books for a more comprehensive review of both the CPSU argument and the challenge to it.
} 
never reinforced by political or legal mechanisms, or imprinted on collective memory. In the end, I argue that this experience of real freedom of action was lost.

\section{A Prelude to August}

While a complete discussion of all of the intricate details that led up to the events of August 1991 and the trial of the CPSU nine months later is beyond the scope of this chapter, some general background is undoubtedly necessary. I therefore begin with a few notes on Gorbachev. In many respects, it is his political choices which set the groundwork for the 1989 Velvet Revolutions of Eastern Europe and 1991 dissolution of the USSR. A career communist, serving under Brezhnev, Andropov, and Chernenko, he was elected by the Politburo Central Committee to the post of General Secretary on March $11^{\text {th }}, 1985$. Having travelled extensively in the West in the 1970s and 1980s, Gorbachev saw the declining standard of living in the USSR as a serious and multifaceted problem. He therefore undertook a program of economic, political and military reforms - perestroika. With the Party as the chief instrument of reform, Gorbachev focussed on making the centrally-planned economy more effective. ${ }^{8}$ The results of the economic program were mixed. Although more goods became available, prices shot up and many people could not afford to buy even the necessities of life. Soviet-produced

\footnotetext{
${ }^{8}$ Between 1985 and 1988 , Gorbachev made five main changes to the way the Soviet economy functioned. First, he decentralized economic planning opting instead for a system of units in charge of the planning, production, and sale of goods. Second, each economic unit was permitted to interact with other sectors of the economy through independent contract negotiations. This allowed for a certain amount of competition and an overall increase in the quality of goods. Third, small business or 'cooperatives' were encouraged in the service and light industry sectors. These businesses were heavily taxed but the state did not dictate their prices on goods often unavailable from state owned organizations. Fourth, Gorbachev relaxed the rules permitting foreign investment in the Soviet economy. Lastly, the rural economy was re-organized so that farmers and individual families could lease state owned land and arrange their production independently. In this way farmers still produced to fill a certain government quota, but were allowed to sell the rest of their harvest or livestock on the open market. For a more detailed discussion of the program of reforms involved in perestroika, see John M. Thompson. Russia and the Soviet Union: An Historical Introduction from the Kievan State to the Present. $5^{\text {th }}$ Edition. (Colorado: Westview Press, 2004).
} 
goods could not compete internationally, waste and mismanagement were pervasive, and sudden shortages and price changes led to widespread hoarding. Generally, while the quality of life in material terms increased for many citizens, predictability greatly decreased, causing dissatisfaction and resentment.

The second prong of Gorbachev's program of reforms was known as glasnost, most commonly translated as openness, although there is no English equivalent for the Russian term. In practical terms, glasnost was a method for tackling the inertia of the monolithic Soviet bureaucracy. People were encouraged to come up with 'fresh approaches' on how to solve the economic and social problems faced by the state. They were also encouraged to report and denounce corruption, poor performance, and general opposition to change. In accordance with these goals, Gorbachev allowed for wider media and academic freedom as well as institutional reform, replacing many established advisors with new like-minded reformists. Glasnost, however, should not be understood as a 'free-speech' or 'democratic' initiative. The Soviet system, its values and leaders, were never meant to be the subjects of criticism. The point was to rejuvenate the system, not to deconstruct it. Nevertheless, the policies of glasnost led to a certain renaissance in Russian literature, film, art and media. Long prohibited books, both domestic and foreign, were published and widely read, and social problems like crime, prostitution and drug use were debated openly. Beginning in 1989, there was also a great deal of 'revelations' made public about the Stalin era repressions. Strictly speaking, however, this information was not new, having been officially acknowledged during Khrushchev's thaw in the 1950s and 1960s. The Politburo Commission's Report on the Rehabilitation of Victims of Political Repression, discussed in the last chapter, was also part of Gorbachev's glasnost. 
Apart from the general reforms that were underway by the beginning of 1991, three separate but interlinked factors played a key role in motivating the putsch planners and eventually in prompting them to action in August. The first was the Lithuanian crackdown. From 1988 onward, many of the USSR republics and Soviet satellite states began to agitate against the central Moscow government. Nationalist movements won popular support and the various communist parties had to distance themselves from the central CPSU in order to maintain a hold on power. In Lithuania, nationalist parliamentarians pushed for a declaration of independence in January of 1991. The socalled 'National Salvation Committee of Lithuania' was formed in response; they communicated their intention to crush the separatists to Moscow in early January. On the night of January $11^{\text {th }}$ Lithuanian troops, led by a special KGB antiterrorism unit dispatched from Moscow, the 'A-7,' stormed the national broadcaster and parliament killing 14 and injuring 604 civilians. ${ }^{9}$ The domestic and international outcry forced Gorbachev to distance himself from some of his closest advisors who had been implicated in authorizing the attack. By early March, Gorbachev ordered the withdrawal of troops from the Baltic States.

Also in March, Gorbachev tried unsuccessfully to oust Boris Yeltsin from his post as chairman of the Supreme Soviet of the Russian Republic. Yeltsin was, however, able to organize a strong showing of support both within the Supreme Soviet and on the streets of Moscow. Choosing not to use troops against peaceful protestors, Gorbachev backed down and began to work with Yeltsin and the leaders of the other republics on the

\footnotetext{
9 John B. Dunlop "The August 1991 Coup and Its Impact on Soviet Politics" (2003) Journal of Cold War Politics, Vol. 5 (1) at 97.
} 
text of the New Union Treaty that would transfer almost all political and economic decision making responsibilities from the central government to the republics.

The last and perhaps most striking event that foreshadowed the August putsch was the July 'constitutional coup' attempted by Soviet Prime Minister Pavlov. Pavlov asked the Supreme Soviet to grant him 'emergency' powers previously only held by the President of the USSR. Although his plan was supported by the KGB and the Ministry of Defence, the Supreme Soviet voted the proposal down after Gorbachev personally delivered a speech against it. Remarkably, all of the ministers involved, including Pavlov, kept their posts. After announcing that the signing of the New Union Treaty would be moved up from October to August $20^{\text {th }}$, Gorbachev left for vacation on August $4^{\text {th }}$.

On the evening of August $18^{\text {th }}$, at his dacha in Crimea, Gorbachev found that all of his phones, including his emergency presidential line to the Kremlin, had been disconnected. A few hours later, a delegation made up of KGB agents, soldiers and political representatives arrived and asked Gorbachev to endorse the authority of an emergency committee that had been formed. When Gorbachev refused he was placed under house arrest. ${ }^{10}$ The GKChP had to proceed without Gorbachev's agreement. The next morning martial law was instituted in Leningrad and Moscow. "[S]olemn classical

\footnotetext{
${ }^{10}$ There is a great deal of controversy about the nature of Gorbachev's confinement. He was guarded by only a few KGB agents and could have attempted an escape. It seems that he chose not to do so. He describes the coup and his house arrest in detail in the second volume of his memoir, Zhisn' i reform. It is also interesting to note that unlike Gorbachev, Yeltsin did in fact manage an escape from his dacha outside Moscow. Although facing a superior force made up of the A-7 KGB squad, at approximately 5 am, Yeltsin and a group of his bodyguards broke down the fence outside his home and sped away in a limousine. Surprisingly, the A-7 agents did not open fire or pursue them. For a detailed, almost hourly, account of the coup see John B. Dunlop. The Rise of Russia and the Fall of the Soviet Union. (Princeton: Princeton University Press, 1993) pp. 186-225.
} 
music - usually played on the death of a Soviet leader" ${ }^{\prime 11}$ greeted people as they began their morning routine on August $19^{\text {th }}$.

\section{Three Days in August}

Although I have gone into some detail above in order to provide a sufficiently comprehensive political and historical background, I focus my discussion of the events that took place between August $19^{\text {th }}$ and August $21^{\text {st }}$ on the actions of ordinary people, both citizens and foreigners, present in Moscow and Leningrad. Below, I argue that people's reaction to the news of the coup and their subsequent actions are an example of a moment of natality. The atmosphere created by the coup was a 'space,' devoid of political institutions which could offer guidance and full of an ever present possibility of physical harm. In this 'space' or 'gap' people acted to resist a certain past and, in Arendtian terms, 'create' the political between them. As such, the gap between past and future in which natality could be experienced opened for people in August; its emergence and disappearance were sudden, yet within it, people became 'challengers' who, "without knowing or even noticing it, had begun to create."12

The GKChP putsch was less than a day old when Boris Yeltsin issued a statement to the Russian people in which he called the coup illegal and urged the release of Gorbachev: "Despite all the difficulties and very grave trials that the people are experiencing, the democratic process in the country is assuming ever deeper dimensions and is becoming irreversible. The peoples of Russia are becoming masters of their own

\footnotetext{
${ }^{11}$ Thompson, supra note 8 at 297.

${ }^{12}$ Hannah Arendt. Between Past and Future. (London: Penguin Books, 2006) at 4.
} 
fate. ${ }^{13}$ Although Yeltsin was careful not to call people to the streets, in part because he did not have any military support to help protect them, leaflets advocating physical resistance to the coup began to appear in Moscow and Leningrad. "There was the swift and unambiguous reaction of the politically active members of society - tens, then hundreds, of thousands of people creat[ed] a living shield around the White House and [took] to the streets of Moscow, Leningrad, and other cities." 14 By the next morning, 200, 000 people demonstrated outside the Moscow City Soviet, 50, 000 gathered at the barricades outside the White House where Yeltsin and his advisors set up a headquarters, and 200, 000 people rallied in Leningrad's Palace Square. ${ }^{15}$

As tanks approached the White House barricades a real sense of impending violence, on the scale that had taken place in Vilnius and Tbilisi only seven months prior, was felt by those present. One woman at the barricades on the night of August $20^{\text {th }}$ wrote: "It was the end of the most terrible, nerve-racking day. The unknown was terrible. The night was sleepless... Desperation, hope, inhuman hatred. But there were already many of us." ${ }^{\text {"16 }}$ Earlier that day the only army battalion, commanded by General Lebed, that was under the control of Yeltsin suddenly left the barricades. This was seen by the protestors as a sign that the White House would be stormed soon. In order to prevent this, people camped out at the barricades. Three young men were killed in scuffle when tanks tried to move closer to the building that night. While some people showed up for demonstrations,

\footnotetext{
${ }^{13}$ Boris Yeltsin. "To the Citizens of Russia." August 19, 1991, 9 am. in Ronald G. Suny eds. The Structure of Soviet History: Essays and Documents. (New York and Oxford: Oxford University Press, 2003) at 465.

${ }^{14}$ Victor Sheinis. "August 1991: A Pyrrhic Victory" (2008) Russian Social Science Review, Vol. 49 (1) at 6.

${ }^{15}$ James L. Gibson. "Mass Opposition to the Soviet Putsch of August 1991: Collective Action, Rational Choice, and Democratic Values in the Former Soviet Union" (1997) American Political Science Review, Vol. 91 (3) at 671.

${ }^{16}$ Bonnell et al, supra note 1 at 83 .
} 
rallies and marches, others printed flyers calling for a general strike, putting the putschists on trial and outlawing the CPSU.

By the evening of the $21^{\text {st }}$ the coup was over. The remaining GKChP members tried to flee through Vnukovo Airport and were subsequently arrested. A delegation was sent to free Gorbachev and return him to Moscow. The Supreme Soviet of the RSFSR began broadcasting instructions over loudspeakers. They ordered the soldiers to return to their barracks, the headquarters of the Central Committee of the CPSU to be seized, and all television, radio and newspaper staff was directed to return to work. ${ }^{17}$ The next day "a crane entered the square in front of KGB headquarters in Moscow, hoisted the statue of Feliks Dzerzhinskii from its pedestal, and lowered it onto a flatbed truck. Cheers and catcalls...accompanied the statue's ignominious exit.",18

In retrospect, many scholars ${ }^{19}$ have written about their surprise at the sheer number of people who showed up in opposition to the GKChP and conversely, at the inability of the GKChP to rally support. These scholars and observers, both Russian and foreign, instead predicted in the months before the coup that "the order-loving Soviet people would welcome attempts to restore the political and social stability that seemed to have crumbled under perestroika and glasnost. ${ }^{, 20}$ The three day stand-off and the popular

\footnotetext{
${ }^{17}$ Lauren G. Leighton, who lived in Russia for two years before the coup working as a Fulbright Exchange Teacher at the Moscow Pedagogical University, wrote "On Novyi Arbat, people stood as if frozen to the sidewalks, listening to the proceedings of the Supreme Soviet of the RSFSR...Every face showed the same expression. I have tried ever since to find a word to describe that expression. Thoughtful is the one that fits the best." in Bonell et all, supra note 1 at 110.

${ }^{18}$ Kathleen E. Smith. Mythmaking in the New Russia: Politics and Memory during the Yeltsin Era. (Ithaca and London: Comell University Press, 2002) at 1.

${ }^{19}$ See for example Frederic J. Fleron Jr., "Post-Soviet Political Culture in Russia: An Assessment of Recent Empirical Observations." (1996) Europe-Asia Studies, Vol. 48: 225-60; Liah Greenfeld. Nationalism: Five Roads to Modernity. (Cambridge: Harvard University Press, 1992); A. V. Obolonsky."Russian Politics in the Time of Troubles: Some Basic Antimonies." in Amin Saikal and William Maley eds., Russia in Search of Its Future. (New York: Cambridge University Press, 1995).

${ }^{20}$ Gibson, supra note 15 at 671 .
} 
dismantling of various symbols of the Soviet past was not a revolution in the proper sense. But it was a decisive turn away from the 'old' order. Unguided by tradition of political institutions, people acted to create and demonstrate the kind of politics they wanted. However, the aftermath of the coup attempt, politically, socially and even legally, failed to make that rejection of the Soviet system permanent.

\section{"We Suffered a Victory"21: Presidential Decrees and a Constitutional Challenge}

On August $23^{\text {rd }}$ and $25^{\text {th }}$, Boris Yeltsin, citing the involvement of the Russian branch of the CPSU, the Communist Party of the Russian Soviet Federal Socialist Republic Communist Party (CP RSFSR), in the aborted coup, issued two presidential decrees against it. ${ }^{22}$ The first decree suspended the activities of the Party and the second seized all of its property. ${ }^{23}$ Three months later, on November $6^{\text {th }}$, Yeltsin issued a third presidential edict that converted the suspension into a ban and formally nationalized the Party's property and financial assets. ${ }^{24}$

These edicts were not entirely unprecedented. Yeltsin had already issued a presidential decree in July of 1991 that "order[ed] the cessation of political parties' activities within Russian state institutions. ${ }^{, 25}$ In his view, the CP RSFSR either helped the GKChP plotters, or alternatively, knew about their plan but did nothing to stop it; in

\footnotetext{
${ }^{21}$ Otto Latsis. Tschatel'no slpanirovannoe samoubiistvo (Moscow: Moscow School of Political Science, $2001)$ at 371.

${ }^{22}$ The CP RSFSR was the party that was targeted in Yeltsin's decrees. Although he also stated that the CPSU's property would be seized if inside the borders of the Russian Federation. However, when the case was finally heard in the constitutional court six months later, at issue was the existence of the Russian Communist Party (RCP) which was now on the political scene in the Russian Federation after the collapse of the USSR and the subsequent disappearance of the Russian Soviet Federalist Socialist Republic. There is some confusion over the changing terminology, even in legal journals especially concerned with the subject. For instance, while Smith refers to it as the CP RSFSR, Sharlet refers to the group as CPR. Although both call the resulting case the 'trial of the CPSU.'

${ }^{23}$ Ukaz No. 79 and No. 90.

${ }^{24}$ Ukaz No. 169

${ }^{25}$ Smith, supra note 18 at 15
} 
either case, the Party had violated the earlier edict. The July edict and Yeltsin's reaction foreshadowed one of the arguments made in the trial. Both the CPSU and the CP RSFSR were accused of violating the 1978 Constitution by "having incited religious, social and national discord. ${ }^{26}$ The real problem with the Communist Party's involvement in the coup, however peripheral it may have been, was that it seemed like an attempt to return to a status quo created by the 1924 Constitution of the USSR in which "no political faction was permitted other than the Communist Party [ensuring that] the single party controlled all organs of the state. ${ }^{27}$ While Yeltsin was careful not to "tar millions of ordinary Communist Party members"28 - totalling about nineteen million in 1991 - his decrees nevertheless made it impossible for the Party to operate.

In a technical sense, the decrees were ultra vires because they exceeded Yeltsin's presidential authority under the RSFSR Constitution. The decrees also "pre-empted prevailing law and usurped judicial functions",29 by dissolving a political party through an executive order rather than through the courts as was prescribed by the USSR

Constitution. At the time of the decrees, however, Yeltsin and many of his advisors, as well as political and legal analysts, expected the Party to disappear quietly.

"President Yeltsin had chosen the day before the $74^{\text {th }}$ anniversary of the Bolshevik Revolution... to issue his third and final decree on the communist system, probably assuming that he was driving the final nail into the coffin of a dead power structure. Yet less than two weeks later, the corpse in the form of the Russian Communist Party was alive and appealing to the new Russian Constitutional Court. ${ }^{, 30}$

\footnotetext{
${ }^{26}$ Smith, supra note 18 at 16.

${ }^{27}$ Neil J. Kritz eds., Transitional Justice: How Emerging Democracies Reckon with Former Regimes. Volume II: Country Studies. (Washington, D. C.: United States Institute of Peace Press, 1995) at 735

${ }^{28}$ Smith, supra note 18 at 16.

${ }^{29}$ Robert Sharlet. "The Russian Constitutional Court: The First Term" (1993) Post-Soviet Affairs, Vol. 9 (1) at 16

${ }^{30}$ Ibid at 17 .
} 
In December, a group of deputies from the Russian Supreme Soviet, known as the

Ivashko-Kuptsov group, appealed to the Constitutional Court. The new representatives of

Communism in Russia carefully distanced themselves from the GKChP members and instead focussed on the plight of ordinary Party members. They claimed that the 'repressive' decrees were arbitrary, that they violated the human rights of communists, specifically their right to association, and that Yeltsin had targeted the Communist Party for elimination because it was his only real political opposition. The CPSU was re-cast in the form of a persecuted dissident. ${ }^{31}$ The final amended complaint to the Constitutional Court simply asked for a review of the constitutionality of the decrees.

Because no one had planned for a 'formal' trial of the regime, lustrations, or even administrative sanctions, the constitutional challenge came as a surprise. ${ }^{32}$ "A Nuremberg-style trial of the CPSU seemed superfluous to many democrats. Most liberal politicians assumed a sufficient break with the past had already occurred naturally."33 The appeal to the court system also seemed ironic in light of the CPSU's stand, taken since the early days of the Bolshevik Revolution, against the authority of the judicial process. As early as 1918, Lenin had declared that the proletariat 'is unrestricted by the law.' Numerous Constitutions had been written over the years, published, and roundly

${ }^{31}$ The first appeal was signed by eight RCP secretaries and appeared in Sovetskaia Rossia on November $16^{\text {th }}, 1991$. It was general political appeal to the public and therefore did not contain specific legal arguments. Various other claims were reprinted in Pravda. For example see, Iurii Slobodkin. "Prezident Rossii perestupil konstitutsiiu, no reshitsia li konstitutsionnyi sud reabilitirovat' kompartiiu?" (May 16, 1991) Pravda, pp. 1 - 3. The second formal petition was signed by thirty-seven Russian People's Deputies and was filed on December $27^{\text {th }}$. This petition contained a thorough examination of the edicts, relevant legislation, and the Russian Constitution. It is recorded in the Konstitutsionnyy vestnik, (1992) Vol. 13: 221 -225 . The counter petition challenging the constitutionality of the CPSU is reported in the same journal, pp. $226-237$.

${ }^{32}$ There would be a trial of the GKChP members on charges of treason in April of 1993. However, no verdict would be delivered because the State Duma granted amnesty to all the GKChP members, along with the participants of the October 1993 Constitutional Crisis, in February of 1994. One GKChP member, General Valentin Varennikov, refused this amnesty and demanded the continuation of his trial, which ended with his acquitted on August 11, 1994.

${ }^{33}$ Smith, supra note 18 at 17. 
ignored by the Party. The judiciary was never regarded as an arbiter, but as a tool used to carry out a political agenda. The rules bent to the will of the Party. Legality and constitutionality was what the Party made of it. Thus, to make an inherently legalistic argument, challenging the validity of decrees seen as outside the scope of a proscribed political power, was a radical departure from Soviet doctrine on the part of the CPSU defenders. A Party that had effectively suppressed core principles of the rule of law for more than seventy years, now asked to be saved by them.

Nevertheless, the Ivashko-Kuptsov petition and the Court's agreement to hear the case, ${ }^{34}$ forced an ad-hoc group of parliamentarians to file a counter-petition challenging the constitutionality of the CPSU and CP RSFSR. Led by Oleg Rumiantsev, a deputy of the Russian Supreme Soviet, the group claimed that these political parties, by their ideology and behaviour, had violated the basic laws governing social organizations in the USSR. Yeltsin appointed two members of his administration and an advisor to file a petition joining Rumiantsev but also independently arguing for the validity of the Presidential decrees. Although presenting a united 'anticommunist' front in court, the two groups made separate yet linked arguments. The presidential group claimed that the Communist Party was not actually a political party but a state apparatus and was therefore subject to unilateral dissolution by the president. Meanwhile, the Rumiantsev group, which made no individual arguments in court but helped with the archival research, argued that the Party had violated the 1978 Constitution, specifically the section

\footnotetext{
${ }^{34}$ The Constitutional Court could have refused to hear the case citing a clause in the original legislation creating the institution which allowed the Court to avoid those cases that invoked 'political questions.' Sharlet argues that the Court did not take this option because of the personal activism of Chief Justice Zor'kin. There are some statements made by the judge in the media before the case was heard which seem to support this claim.
} 
dealing with social organizations. All of the petitions and counter petitions were united by the Constitutional Court into a single case in May of 1992. Before moving onto the specific arguments of each group, primarily their re-interpretation of Soviet history, I want to make a few notes about the composition of the Court and the sheer uniqueness of this trial. Both elements contributed to the 'political' nature of this case of political justice and therefore deserve mention.

This trial from its inception was a unique case of transitional justice, both alike and different from other cases in the field. First, it was the 'defeated' communists, even if they were self-appointed representatives of the regime and not members of the former elite, who brought the matter to the court. In fact, the petition was characterized as an "unwanted challenge to...legally shaky decrees." 35 Even though the burden of proof would shift after the Court unified the original petition and counter petition into a single case, thereby effectively moving the CPSU from plaintiff to defendant, the original challenge was an attempt at securing a 'second chance' for the CPSU. In this regard there is a similarity between this case and the Israeli trial of Rudolf Kastner discussed in chapter one. In that trial, the burden of proof also shifted to the complainant, Kastner, even though officially the case was meant to resolve charges of criminal liable brought against Malchiel Gruenwald. Moreover, although both the trial of the CPSU and Kastner's trial transcended the legal issues at stake in the courtroom, instead focussing the debate on the meaning of a contested historical narrative, the Kastner trial challenged the past making it a "full-blown political trial perceived by the Israeli public as touching

${ }^{35}$ Sharlet, supra note 29 at 19. 
on the most urgent issues of the day." ${ }^{, 36}$ The trial of the CPSU, on the other hand, ended up validating, not challenging the past. The Communist Party defenders were able to make the Soviet legacy into a political tool in the present, while their opponents failed to grasp the significance of a cohesive national narrative, instead concentrating on discrediting pieces of a distant past. The key failure to utilize historical narrative effectively by those seeking a transformation in either national identity, as in Israel, or polity, as in Russia, would be the contrasting factor in one trial being an example of political justice fulfilled and the other only political justice attempted.

The setting of the trial, the Constitutional Court itself and the laws which governed it, also made this trial distinctive and added to the confrontation between the old and new systems. But within the boundaries of transitional justice cases, the fact that the Court struggled with the applicability of old laws and issues of retroactivity, actually made this trial more akin to its various counterparts throughout the world. The issues here did not involve criminal law; there was no debate about the statute of limitation or the feasibility of prosecuting state-sanctioned bureaucratic murder like the debates in Hungary or Czechoslovakia. The central legal dilemma for the court, the question of how to evaluate the constitutionality of a state apparatus which made the rules it was now accused of breaking, touched on the same issues of legitimacy that other transitional justice cases dealt with. Beyond the law, the structure and staffing of the Court is also of some interest when looking at a period of transition.

The original statute outlining the extent of the Court's powers was passed by the Russian Supreme Soviet in May of 1991. As mentioned before, the idea of 'supremacy of

\footnotetext{
${ }^{36}$ Leora Bilsky. Transformative Justice: Israeli Identity on Trial (Ann Arbor: The University of Michigan Press, 2004) at 20.
} 
law' or 'judicial oversight' was unheard of in the Soviet system. Thus, the Court was a radical departure from the established institutions of law and was an original creation. But while the court itself was new, the people who staffed it were well-established members of the Soviet legal system. For them, 'constitutionality' was an untested legal principle, foreign to the system within which they had worked and were educated. For example, Chief Justice Zor'kin was educated at the Moscow University Law School where he later lectured as a member of the school's law faculty. Zor'kin also taught at the Academy of the USSR Ministry of Internal Affairs (MVD) before being appointed to the Constitutional Court. In 1990, he helped in the initial drafting process for the Russian Constitution. And while he signed a letter protesting the GKChP coup in August, he remained a member of the CPSU until October $30^{\text {th }}, 1991 .^{37}$ Commenting on his Party membership, Zor'kin later said: "I have no past work for which I should feel ashamed. We all moved through this system, each doing it his own way." ${ }^{38}$ Zor'kin's colleagues had similar work histories and all were former members of the CPSU; they had all 'moved through this system.' Furthermore, the law under which the case would be heard was the 1978 Constitution of the USSR, which was still in effect when the decrees were made but which was in the process of being replaced by the new Russian Constitution when the case was finally heard. At issue was Article 6 of the Constitution which read in part:

"the leading and guiding force of the Soviet society and the nucleus of its political system, of all state organisations and public organisations, is the Communist Party of the Soviet Union. The CPSU exists for the people and serves the people. The [CPSU]...determines the general perspectives of the development of society and the course of the home and foreign policy of the

\footnotetext{
${ }^{37}$ Sharlet, supra note 29 at 12.

${ }^{38}$ Steven Erlanger. "Russian Court Weighs Communist Party's Legality" The New York Times (8 July 1992) at A8.
} 
USSR, directs the great constructive work of the Soviet people, and imparts a planned, systematic and theoretically substantiated character to their struggle for the victory of communism [emphasis added]. ${ }^{39}$

This key article, the so-called 'party-hegemony' article, which effectively ensured one party rule in the Soviet Union, was voluntarily abolished by the CPSU in 1990. As a result, during the trial, the defenders of the CPSU argued that the Party was in the process of reform, dividing party and state structures, when the coup happened.

\section{Debating a Near and Distant Past}

"Somewhere to the side of the daily political struggles that dominated posttotalitarian Russia, a historical sideshow had begun - a judicial battle over the life, death, and potential resurrection of the Communist Party. ${ }^{, 40}$ At the time, commentators called this trial a bid to put "history in the dock. ${ }^{41}$ The proceedings were labelled in various pejorative ways: as a show trial, political trial, political diversion, political farce, a failed Nuremberg, and the equivalent of a meeting of the Communist Party Central Committee. Here, I argue that this case was in fact a political trial. And it certainly contained theatrical moments. The trial never aspired to the scope of Nuremberg, nor was it ever so limited or partisan as to be compared with a 'party meeting.' While the Constitutional Court heard historically based arguments, in this way putting 'history on trial,' I contend that it delivered no definitive or guiding verdict on history. The trial, therefore, did not fully reckon with the past and therefore never captured natality.

\footnotetext{
${ }^{39}$ Translated by Novosti Press Agency Publishing House. (Moscow, 1985) available on-line: http://www.departments.bucknell.edu/russian/const/1977toc.html

${ }^{40}$ David Remnick. Lenin's Tomb: The Last Days of the Soviet Empire. (New York: Random House, 1993) at 505 .

${ }^{41}$ This comment is attributed to Gorbachev, who was sceptical about the entire judicial process and refused to participate in it. In an interview with David Remnick in 1992, Gorbachev said: "Look, I am not going to take part in this shitty trial." Remnick, ibid at 506.
} 
As discussed in chapter one, political justice and political trials are not always, or only, about power. The CPSU was a relic at the time of this trial. Nothing could be done to return it to its former state. The Party as it existed in August of 1991 was, to borrow Yeltsin's expression, 'doomed.' And while the CPSU defenders had gone on the offensive and caught the democrats by surprise with their petition, in the end they were squarely placed in the role of the defendant having to answer for the Soviet legacy. Yet this proved to be somewhat of an advantage. The CPSU defenders had nothing to lose and everything to gain through this case. Minimally, the Party stood to regain all of its seized possessions. Maximally, it could be elevated back to political legitimacy. Therefore, while this trial was not about political power, it was, in essence, about politics. Specifically, the trial was about the politics of the past and the politics of identity. What role would Soviet history play in the future? What corner of the political plurality developing in Russia could the Communist Party justly claim as its own? The ability of each side to effectively bind together the past and present into a cohesive narrative proved to be a key element throughout the trial.

For the purposes of clarity I have paired the arguments down into more cohesive strands of reasoning. It should be noted that the two opposing sides did not always engage directly with each others' arguments, or concern themselves with the legal issues in question, which can be summed up as: Was the CPSU involved in the August coup? What kind of organization was the CPSU under Soviet and Russian law? Did Yeltsin's decrees surpass Presidential powers as proscribed by the laws of the RSFSR? Although the first and third questions were the most legally pertinent, the case, by looking at Soviet history, largely focussed on the second question. I therefore also make this issue my main 
point of analysis and begin with the arguments made by the CPSU defenders, the socalled Ivashko-Kuptsov group.

The CPSU defenders began by asserting that the Party was by far the largest social and political organization in Russia. Its nineteen million members did not support the Party because of oppression or force, but out of a sense of loyalty. During the trial, the CPSU lawyers pointed to examples of war-time heroism and sacrifice committed by soldiers and civilians as proof of this loyalty. ${ }^{42}$ The pace at which the Soviet economy was rebuilt after WWII, as well as the major technological achievements, especially in the area of space flight, were touted as examples of the Soviet people's commitment to the Communist Party. "With these examples, the CPSU's advocates unerringly pointed to the least controversial, most untarnished national achievements during the seven decades of Soviet rule." ${ }^{43}$ The CPSU supporters carefully picked through Soviet history, polishing certain parts of it and putting them on display. Throughout the arguments, the CPSU defenders moved between the past and present, successfully tying together sixty year old events with the contemporary struggles faced by ordinary citizens. They avoided the mention of Lenin or the Revolution, instead sticking to those moments in history which were relevant to the present generation of Party supporters.

It would be a gross understatement to say that the arguments of the CPSU supporters were paradoxical. In their attempt to simultaneously make the most of the past

\footnotetext{
${ }^{42}$ The CPSU lawyers also did not draw attention to some of the harsher orders issued by Stalin during the war to guarantee this loyalty from soldiers and their families. For example, Order No. 270 authorized superiors to shoot their troops for desertion or insubordination; the families of these men were subject to arrest. Further orders from Stalin and Beria directed that soldiers found guilty of 'conduct offences' be put into 'punitive battalions' which were sent into the most dangerous areas of fighting. Half a million troops were assigned to these battalions. In places like Stalingrad, were the fighting was severe, Stalin ordered that 'blocking brigades' be set up behind the front lines to in order to shoot soldiers who tried to retreat. See, Robert Conquest. The Harvest of Sorrow: Soviet Collectivization and the Terror Famine. (London: Pimlico, 2002).

${ }^{43}$ Smith, supra note 18 at 19.
} 
and the present, the lawyers for the CPSU argued that the Communist Party of Russia was a new organization, constituted in 1990 and acting within the confines of the reformed 1978 Constitution. The new Party was not the re-incarnation of the CPSU and its actions should therefore be disconnected from any unlawful actions, past or present, taken by the CPSU. The CPR was always only a political party, it had never interfered with the actions of any state organs and it was in no way part of the GKChP coup. Yet, while they relied on the 'newness' of the CPR to defend it against charges of unconstitutionality, the CPSU supporters also pointed to the 'reformatory' nature of the CPSU throughout the last seventy years. After all, this was the same Party that under Khrushchev spoke out against Stalin's cult of personality in 1956. It was the Party of perestroika. It had voluntarily abolished Article 6 of the Constitution. It was in the process of reform when unfairly banned. The CPSU defenders reiterated time and again that the Party was responsible for all democratization.

Moulding history, the Party distanced itself from the economic downturn and the political instability prevailing in the country at the time of the trial, instead adopting the role of victim. This, again, took into account both the historical events and the present day situation. First, the CPSU was not the instrument that Stalin used in order to repress the Soviet population. According to the CPSU defenders, the Party was actually Stalin's greatest victim. “Against whom was Stalin's first and main blow, when he carried out a counterrevolutionary coup in the nation? Among what social groups, parties, if one can speak of parties, were there the greatest number of victims? Among the Communists. ${ }^{, 44}$ The Party was a victim of circumstance both then and now. Having been victimized by

\footnotetext{
${ }^{44}$ Valentin Falin, a former member of the Central Committee of the CPSU. Smith, supra note 18 at 20.
} 
Stalin, the Party was now being scapegoated by Yeltsin, blamed for the failure of his economic restructuring and the collapse of superpower status. "The mantle of victim clearly had a strong appeal, not only because it fitted the dismay and chagrin of the Party members upon finding their organization banned, but because it fitted a popular mood as well. With the dissolution of the USSR...many Russians felt like the vanquished rather than the victors. ${ }^{, 45}$ The CPSU defenders even managed to use the GKChP coup to their advantage. They claimed that since no official charges had been brought against the coup members at the time of this trial, no evidence of Party participation could be introduced. They went further to suggest that the coup was actually orchestrated by Gorbachev to liquidate the Party without resorting to judicial measures. "This was a coup? No, I am sorry. This was a drama, designed to crush the Communist Party and create a bourgeois power in Russia." ${ }^{46}$ The claim picked up on rumours started on the first day of the August coup and seemed to resonate with many people in the general public even though a committee established by the Supreme Soviet had uncovered coded telegrams sent from the CPSU secretariat to all Party committees urging their support for the coup. ${ }^{47}$

While the Party was quick to assume the posture of victim, its supporters vehemently denied any claims of collective culpability. They did this through several mechanisms, again mixing the past and present. First, although they denied their involvement in the August coup, the CPSU supporters argued that if the Party had interfered in state activities, and thereby technically violated constitutional norms, it was always done with the best interests of the people in mind. "Party officials defended their

\footnotetext{
${ }^{45}$ Smith, ibid at 23.

${ }^{46}$ Vladimir Ivashko as quoted by David Remnik in "The Trial of the Old Regime" (30 November 1992)

The New Yorker, at 110.

${ }^{47}$ Sharlet, supra note 29 at 24.
} 
'interference' as well intentioned, generally successful efforts to make better public policy and to increase economic efficiency." ${ }^{48}$ Furthermore, these good intentions were always carried out by single individuals; the Party as a whole was never implicated. Following from that assertion, the CPSU supporters also claimed that the Party had always been divided between progressive 'true believers' and power hungry 'careerists.' "Our side defends here not Stalin and not Gorbachev, not those scoundrels who operated using the name of the Party as cover. It defends the Communist Party of the Soviet Union as a political organization that represents the interests of the working people." ${ }^{, 49}$ Accordingly, CPSU supporters claimed that they wanted control of Party property, seized by Yeltsin, not to enrich themselves but to hand it over for public uses like housing legal institutions and helping to produce literature.

Lastly, and perhaps almost as effective in the Russian context as claiming the status of victim, the CPSU defenders used the tactic of 'clean hands.' Witnesses, jurors, prosecutors, politicians, members of the press, and the general public were continually reminded of their membership in the Party. Each witness was asked when they joined and when they resigned from the Party and, crucially, if they had ever acted unconstitutionally as a member of the Party. While those that testified against the Party claimed that they had now re-evaluated their actions, no one would admit to joining an 'unlawful organization' or to knowingly acting unconstitutionally. The witnesses that testified on behalf of the Party boasted of the pride they felt in their membership. They would not admit feeling any shame or remorse.

\footnotetext{
${ }^{48}$ Smith, supra note 18 at 21.

${ }^{49}$ V. Kupson. "Nadeemsia" as quoted in Smith, ibid.
} 
In sum, although some of their arguments were contradictory, the CPSU supporters weaved the past and present together well. By leveraging the worsening economic situation in the country against feeling of nostalgia for the 'good old days,' the CPSU was able to reclaim a certain respectability and validity. The CPSU defenders created an image of the Party as war hero and victim of circumstance, downplaying the legacy of Stalin while promoting the achievements of his time. Most importantly, while never acknowledging anything close to collective culpability, the CPSU supporters time and again reminded the Court and the public of their membership, their involvement, and their implicit support for the Communist Party.

The strategy of the counter petition initially filed by Rumiantsev and later joined by the presidential team, also relied heavily on the use of history. But unlike the CPSU's supporters, the democrats launched what would be most accurately called a war of details. Using their access to the newly seized KGB and CPSU archives, the democrats had two basic strategies: to draw attention to the numerous large scale human rights violations committed by the Party and to prove the Party's unconstitutionality by illustrating the many every-day ways it interfered in the affairs of the state and violated legal norms. With scrupulous attention to detail and legal technicalities, the democrats tried to discredit the more grandiose claims made by the CPSU supporters. However, their arguments, although a more accurate portrayal of Soviet history, had less impact on the general public. There was a simple reason for this. Everything the democrats claimed about the CPSU, even when they discussed the most serious offences, was already widely known by the general public. "I think we're trying to break down open doors, what we want to prove what, in my opinion, is known by 99 percent of the population who have 
lived in these conditions." 50 The democrats offered, not a shining glimpse of history through the lens of nostalgia, but a stark reminder of just how bad the bad old days were. In the end, the hundreds of thousands of documents introduced as evidence by the democrats proved nothing new to anyone and most were deemed irrelevant to the legal issue at hand by the Court. The democrats lacked a grand narrative and this made their arguments less publically appealing.

Although the CPSU defenders were successful in proving that Yeltsin had overstepped the bounds of his authority when he issued the three decrees, the democrats were equally successful in proving that the Party had never been a political party or voluntary social organization.

"According to every canon of the Marxist-Leninist theory of the state and the law, we had a state that called itself the CPSU. There was a particular group of persons who dealt with the government and had a monopoly on the state: the one and a half million people in the Party nomenclature, several million civil servants, and, finally, the special apparatus of coercion...Essentially we had a regime in which the basic law of the state and society were the rules of the Communist Party [emphasis added]." ${ }^{, 51}$

Using both recent examples, like the orders to invade Afghanistan or the attempted coverup at Chernobyl, and more distant ones, like Stalin's orders to execute Polish soldiers in Katyn during WWII, the democrats demonstrated again and again that the Party made state policy. They reviewed the history of the secret police, calling witnesses who had spent the majority of their lives in prison camps to testify about their imprisonment. The democrats explained how the Party actively funded left-wing movements in other countries and how it allocated funds to 'education.' For every official document on

\footnotetext{
${ }^{50}$ From the testimony of V. Bakatin, as quoted by Smith, supra note 18 at 25.

${ }^{51}$ Sergei Shkhrai, Yeltsin's chief advocate in the trial of the CPSU, quoted in Remnick, Lenin's Tomb, supra note 40 at 509 .
} 
policy, the democrats produced volumes of archival evidence about 'real' policy. To address the argument that the Communist Party of Russia was a new entity and that the CPSU had begun a process of reform when it was banned, the democrats produced documents that showed various high ranking Party officials communicating their support for the GKChP in August. In opposition to the theme of pride and non-repentance, the witnesses that testified on behalf of the democrats admitted remorse for their membership in the Party. "Yeltsin [and members of the CPSU leadership] bore some responsibility...there were no 'islands of legality' - everyone should shoulder some of the blame. 52

Generally, the democrats took Russians on a crawl through history. ${ }^{53}$ The technique was ineffective. In the legal arena, the tactic failed because the Court refused to condemn the system in its final ruling, and the public at large was not interested in hearing facts known to "every kid in school." ${ }^{.54}$ I have already mentioned that for the CPSU defenders this trial was a chance at regaining legitimacy and that the side which had the most to lose were the democrats. To add to this, treating the decrees and the subsequent trial as an afterthought, epilogue or post-mortem turned out to be a selfdefeating approach for the Yeltsin team. The democrats did not, and perhaps could not, see the value of firmly cementing a historical narrative. They overburdened the public and the court with hundreds of thousands of details at the expense of the larger picture. Ironically, it may have been the enormous size and endurance of the Soviet regime which

\footnotetext{
${ }^{52}$ Smith, supra note 18 at 25 .

${ }^{53}$ Kazimierz Brandys originally wrote: "Westerners stroll through life while East Europeans crawl through history." A Warsaw Diary 1978 - 1981, trans. by Richard Lourie. (New York: Random House, 1983) at 165.

${ }^{54}$ Remnick, Lenin's Tomb, supra note 40 at 510.
} 
saved the CPSU in the end. The scope of the various atrocities, extra-judicial killings, propaganda campaigns, economic measures, and a general policy of repression, was so immense that the details failed to make an impression. Most crucially, these details did not serve a political purpose. Instead, the democrats seemed to alienate people still loyal to, if not the regime in general, the memory of that regime. The ostentatious claims of the CPSU defenders, on the other hand, put enough of a gloss on the events of the past to make them useful to the political present. The CPSU defenders were able to create a historical narrative which bridged past and future, leaving the Party in a key role. The democrats could not offer a cohesive counter narrative; the war of details was perhaps a more accurate representation of history, but a scattered one, not easily governed by a common theme. Yet for all the historical rhetoric during the trial, the final decision of the Court, which I discuss below, turned out to be a highly legalistic one. The Court avoided sweeping condemnations or affirmations of the regime, opting instead for an approach best described as a compromise. While this decision accorded with the principle legal issues at stake during the proceedings, it failed to recognize the significance of the trial or the various historical arguments raised by both sides. It was not a final judgment on Soviet history or the Party. In a trial dominated by the past, the verdict was concerned chiefly with the present.

\section{Judging History: The Verdict of the Constitutional Court}

The judgment of the Court was delivered on November $30^{\text {th }}, 1992$. It was technical, detail oriented, ambivalent in some respects, and surprising in others. In the end, the Court managed to clearly condemn the CPSU leaders, but it faltered when commenting on the system as a whole, preferring instead to leave the ultimate fate of the 
Communist Party to the people. The court began by dissecting the three presidential decrees. The question of constitutionality largely rested on whether or not the Party was a political or social organization. The CPSU defenders, as discussed above, challenged the constitutionality of the presidential decrees by calling the CPSU a social organization which could only be dissolved through a judicial process or by the president in a state of emergency. Since an official state of emergency had not been declared on August $23^{\text {rd }}$, the president had overstepped his powers by issuing the edicts. The democrats had countered that while the CPSU was never a social organization, citing many examples from history which demonstrated continual interference of the Party is state affairs, they also argued that the Communist Party of Russia (CPR) and the Communist Party of the Russian Soviet Federalist Socialist Republic (CP RSFSR) had never registered as social organizations, as required by the Constitution, and therefore never gained that legal status. The ruling cut both ways. The Court decided that the CPR and CP RSFSR never needed to be officially registered, thereby invalidating the pre-amble to the first presidential decree, and that these parties were not new entities but rather extensions or re-incarnations of the CPSU. Referring to the Party's own charter, the Court ruled that the CPSU was the main organ of the Communist Party and had been fundamentally unchanged by the March 1990 creation of the other two parties. "All documents of the CP RSFSR testify to the fact that it considered itself as a structural part of the CPSU." 55

\footnotetext{
55 "In the Case of the Verification of the Constitutionality of Edicts of the President of the Russian Federation No. 79 of 23 August 1991 'On the Suspension of the Activity of the Communist Party of the RSFSR,' No. 90 of 25 August 1991 'On the Property of the CPSU and the Communist Party of the RSFSR,' as well as of the Verification of the Constitutionality of the CPSU and the CP RSFSR." (1992) Constitutional Court of the Russian Federation. Statutes and Decisions: The Laws of the USSR and Its Successor States. $30(4)$ at 15.
} 
This finding negated the CPSU defender's arguments about the fundamental separation between the original CPSU and the successor parties and by the same token that the 'new' communists should not be judged for the crimes of the 'old' communists. Instead, the Court affirmed that three entities were in fact all part of the CPSU. The decision further meant that while the government could not punish the CPR or CP RSFSR for not registering their status, the two parties could not "become independent owner[s] of property apart from the CPSU." ${ }^{, 56}$ In essence, it was the CPSU that could claim an infringement on property rights by challenging the constitutionality of the presidential edicts, not the two off-shoot parties.

The Court reached its most significant conclusions when dealing with the issue of whether the CPSU could be legally disbanded by the president because of its unconstitutional involvement in state affairs. After all, Article 6 of the 1978 Constitution, the 'party-hegemony' provision, had been voluntarily abolished by the Party in 1990 , signifying its commitment to political plurality. The question was whether the Party had actively interfered in state affairs since then and whether this interference constituted a legal ground on which the Party could be disbanded. The Court first found, as a matter of fact, that the CPSU had communicated its intentions to support the GKChP coup. ${ }^{57}$ Given that the Party had obviously supported the coup, the Court ruled that the president was within his powers to suspend its activities.

\footnotetext{
${ }^{56} \mathrm{Ibid}$ at 17 .

${ }^{57}$ The evidence cited by the Court was not overwhelming. But there is a very good reason for this. Remnick documents the way that party bureaucrats systematically tried to destroy evidence of their complicity in the days immediately following the GKChP leaders' arrests. With crowds of protestors gathering outside, "the dictators of the proletariat and their assistants at the Central Committee headquarters ransacked their desks and emptied their safes. They fed one incriminating document after another into the shredding machines...But then the shredders began to jam and break, one after another. In their haste, the men of the Party had failed to remove the paper clips" supra note 40 at 493.
} 
In addition to clearly interfering in state affairs even after abolishing Article 6, the Court also concluded that the CPSU was never a social organization or a political party. It had not been envisioned as such "for this would have fundamentally contradicted the actual status of the CPSU as the "leading and guiding force of society." two very significant implications. First, in terms of property, the CPSU could not demonstrate legal ownership. "The lack of clarity of the subjects of the right of ownership of the property under the administration of the CPSU and the CP RSFSR does not permit an unambiguous recognition of them as the owners thereof." 59 The Court could find three potential owners of Party property: the Party itself, the state, and private owners. But since throughout its history the CPSU had controlled all of this property, delineating which property belonged to which owner was nearly impossible. As a result, the government could not seize the property of private owners, but the Party could not prove which properties, except for union dues, belonged exclusively to it. Implicit in this conclusion was the Court's most significant finding: the CPSU acted in place of the state. For all intents and purposes, the Communist Party was the Soviet State. No amount of official statements made after 1990 changed that fact. This finding is significant enough to be quoted in full:

"Over the last of a lengthy period of time, a regime of unrestricted power, relying on force, of a narrow group of Communists functionaries untied in the Politburo of the Central Committee of the CPSU, headed by the General Secretary of the Central Committee of the CPSU, reigned in the country...By the materials of the case, including the testimony of witnesses, it is confirmed that the leadership structures of the CPSU were the initiators...of a policy of repression in relation to millions of Soviet people...This continued for decades. After the amendment of Article 6 of the Constitution of the USSR, as in previous years as well, the organizational structures of the CPSU decided

\footnotetext{
58 'In the Case of', supra note 55 at 25.

${ }^{59}$ Ibid at 26.
} 
many questions falling within the competence of the corresponding bodies of power and administration." 60

This remains, to this day, the most serious legal denunciation of the CPSU.

Nevertheless, this judgment was not a condemnation of the Soviet system as a whole or of the Party structure. In fact, the Court went on to make very clear the innocence and disassociation of what it referred to as 'the rank and file members.'

"Materials in the case testify to the fact that in the overwhelming majority of cases the leadership bodies and the highest officials of the CPSU acted in secret from the rank-andfile members." ${ }^{, 61}$ The Court suggested that Party members' culpability was diminished because they merely 'rubber-stamped' the decisions of their superiors and were never in a position to question those decisions. These ordinary men and women "were never able to attain a decisive influence in their organization." ${ }^{, 62}$ Furthermore, the Court placed a great deal of value, both politically and legally, in the separation between the leadership of the CPSU and the ordinary members. Accordingly, the Court found that the disbanding of the Party in its entirety was unconstitutional and unfairly punished ordinary citizens.

"Membership in the Communist Party and prior work in it do not serve as grounds for any discrimination whatsoever; and new parties of a Communist orientation [can be] created without hindrances." ${ }^{, 63}$ Therefore, while the leadership structure, above the level of raikom, ${ }^{64}$ was rightly prohibited, the primary CPSU organizations, at the territorial

\footnotetext{
60 'In the Case of', supra note 55 at 29.

${ }^{61}$ Ibid.

${ }^{62}$ Ibid at 33 .

${ }^{63}$ Ibid at 34 .

${ }^{64}$ Raikom is the regional committee within a city Party organization; it is the second lowest organizational level in the CPSU.
} 
level, were encouraged to meet and create new leadership structures. The base of the CPSU was left intact.

\section{Meaning and Consequence}

This verdict was a compromise. It did not seize the moment of natality, reckoning with the past only partially, and therefore could not meet in full the transformative potential of political justice. In the end, the Court did not condemn the Soviet system as a whole, but it also avoided invalidating the presidential decrees which would have significantly weakened Yeltsin's already precarious political position. Despite this outcome, which was really judicial 'Solomon-ization' between political agendas, I think the language of political expedience should not be used to undercut the significance of the entire case. Political justice, after all, does not take place in a vacuum. There are always political pressures and this is even more so for political justice in transitional periods. Furthermore, the circumstances which made real reckoning with the past problematic in this trial were the very same ones responsible for providing the potential for a moment of natality. The 'newness' of the post-USSR state, the fragility of the system, necessitated two contradictory outcomes: a compromise verdict and an uncompromising final judgment passed on the nature of the old regime. There are many reasons for why a political compromise was needed. The economy was in free-fall; the public was growing ever more dissatisfied with the new leadership; Yeltsin was in a life and death struggle for control with the Parliament. The Constitutional Court refused to add fuel to the political fire by delivering an outright condemnation of the CPSU and the Soviet past. The famous journalist and author, Otto Latsis, wrote that the "court disarmed 
a political landmine of unpredictable force." ${ }^{, 65}$ While perhaps politically 'effective' at the time, I argue that by avoiding a comprehensive judgment, this decision was adequate law that made for temporary good politics and lasting bad history.

There are many reasons why a final verdict was needed, and is, perhaps, still needed. I point to only two here. Strangely, although related, one of them is often commented on while the other has been largely absent from both academic and popular discussions. The first reason for why a judgment of the Soviet legacy was needed has to do directly with the arguments made by the CPSU defenders at trial and the counterarguments made less loudly by the democrats. The issue at stake for both sides, and one that had the potential to impact the formation of memory and identity, is that of collective culpability. The CPSU defenders simultaneously embraced and repelled culpability. They denied it by emphasizing the positive nature of the Party, its good intentions and contributions to society. Party members had nothing to be ashamed of or to feel culpable for. Yet they also utilized it in a negative way by suggesting that if they had something to be ashamed of, so did everyone. As already mentioned, the scope, scale, and endurance of the Soviet system greatly aided them in this respect. The democrats also tried to utilize collective culpability. They admitted their own responsibility and urged others to do the same. The problem with this technique, and with the attempts to assign collective culpability generally, is that it asks those responsible to voluntarily judge themselves. This is especially problematic in the Russian context. The other republics, not to mention the satellite states, could, to some extent, shift the blame to an 'outside' or 'imposed' system of control which originated in Moscow. Russia, on the other hand,

${ }^{65}$ Izvestiia (News) (1 December 1992) at 2 as quoted in Donald D. Barry "Trial of the CPSU and the Principles of Nuremberg" (1996) Review of Central and East European Law, Vol. 22 (3) at 260. 
could look to no one but herself. Not surprisingly, many people were unprepared or unwilling for this sort of self-examination. Arseny Roginsky, one of the founders of Memorial, summarized the problem directly when interviewed during the trial: "Here we must judge ourselves. We judge each other. And who is unsullied? Who was a pure victim of the Party? Who was not complicit? I realize that is not the stated purpose of the Constitutional Court, but those are essential questions. ${ }^{, 66}$ Those essential questions were never dealt with. As a result, culpability in Russia has been placed on some exterior 'other.' Everyone was involved, but no one was responsible. By singling out the leadership structures of the CPSU, the Constitutional Court re-enforced this view. The trend continues today, with the majority of discussions about any 'crimes' committed firmly identifying the culprits as the long-dead Party hobgoblins, like Lenin, Stalin and Beria. Yet even these men, Stalin in particular, have been rehabilitated to some extent recently with positive historical accounts and media coverage. ${ }^{67}$ The Court's endorsement, even if only passive, of a limited construction of culpability mainly focussed on the Party elite, is also connected to the other major flaw of the historical judgment in this case.

The opinion, shared by Yeltsin's advisors and the democrats, that the Communist Party had largely died a 'natural death' was re-iterated by the Constitutional Court. As a result, it declined to rule on the issue of constitutionality because "the communist party in effect collapsed during the last part of 1991."68 This is significant because while the

\footnotetext{
${ }^{66}$ Remnick, Lenin's Tomb, supra note 40 at 506.

${ }^{67}$ In 2008, Stalin was one of the choices for Russia's greatest historical figure in the 'Name of Russia' television project. He came in third. See, Tom Parfitt. (29 December 2008) "Medieval Warrior overcomes Stalin in poll to name Greatest Russian" The Guardian, available on-line: http://www.guardian.co.uk/world/2008/dec/29/stalin-name-of-russia.

${ }^{68}$ Barry, supra note 65 at 259.
} 
Court acknowledged the fact that the CPSU was never a political party or social organization it did not condemn the general structure of the CPSU or label it unconstitutional and illegal. When it came down to one of the most important and vital issues at hand, namely the legality of the Soviet apparatus which had ruled the country for seventy plus years, the Court skirted the issue. There are those scholars, like Yuri Feofanov, who argue that the Court should have taken a more 'Nuremberg-style' approach. His argument is essentially that the Bolsheviks seized power by force and ruled through force. While the institutions that the Party set up had the outward appearance of legality, they were mere façades, portals through which direct power was channelled. Therefore, "the CPSU continued to suppress the people...legality was superimposed over what was, in effect, a criminal core." ${ }^{69}$ His conclusion is that the Court could have ruled, in a manner consistent with the Nuremberg Tribunals, that the CPSU was 'legal but criminal.' The Party, through its actions, had set itself outside the law; it operated without restraint in a legal framework that it created and changed as the need arose. I think the argument about the nature of the CPSU is a compelling one, though not without some problems. Obviously, a direct link between the Nuremberg Tribunals and the CPSU trial cannot be made. The CPSU trial was not a criminal proceeding; it did not judge the guilt or innocence of single individuals. It may, therefore, have been unreasonable to expect the Court to step outside the legal issues at stake. Yet the Court had already come close, by recognizing that the CPSU was not a political party but a mechanism that ruled the state. The Court could have, at least symbolically, labelled the Soviet machinery for what it truly was: a totalitarian dictatorship, propagating an ideology, clothed in the form of a

\footnotetext{
${ }^{69}$ The summary belongs to Barry and is compiled from a chapter entitled 'Russia's Nuremberg' in Politics and Justice in Russia and an article entitled "The Establishment of the Constitutional Court in Russia and the Communist Party Case." (1993) Review of Central and Eastern European Law, Vol. 19 (6).
} 
political party. Such an identification of the entire system, not only the leadership or various individual components, would have been both meaningful and valuable. Apart from the historical significance, it would have also clearly drawn a line in the sand between the way things had been and the way they were to be from now on. Instead, "[r]ather than mark the beginning of a new system of rule, the trial emphasized continuity between the Gorbachev and the postcommunist era.",70

\section{Conclusion: "how things take place without significance"71}

The Constitutional Court ruled that the Communist Party members could rebuild from 'the ground up' after the decision. And this is exactly what they did. In February 1993, a 'revival-unification congress' was held at which the Communist Party of the Russian Federation (KPRF) was officially formed and declared its intention to be the legal heir of the CPSU. "Justice Ernst Ametistov and others later argued that the actions of this congress already violated the spirit of the Constitutional Court's decision, but no legal steps were taken to challenge the KPRF's pretensions." 72 At present, the KPRF remains Russia's best organized and most enduring political party. In March of 2000, Genadii Zyaganov, the party's candidate for president, came in second with 21.9 million votes. ${ }^{73}$ Today, the KPRF largely survives by trading on nostalgia and inertia. It is not alone in this practice. The leader of the Liberal Democratic Party of Russia, Vladimir Zhirinovsky, has made several speeches against rehabilitation and compensation for victims of political repression. Much like the CPSU defenders, he claims victimhood and

\footnotetext{
${ }^{70}$ Smith, supra note 18 at 28.

${ }^{71}$ Sergei Prozorov. "Russian postcommunism and the end of history" (2008) Studies of East European Thought, Vol. 60 at 209.

${ }_{72}^{72}$ Smith, supra note 18 at 28.

${ }^{73}$ Luke March. The Communist Party in Post-Soviet Russia. (New York: Manchester University Press, 2002) at 257.
} 
non-repentance in the same breath. "We have the right to forgive them all - from Kaliningrad to Kamchatka...No one is guilty of anything." ${ }^{.74}$ It would seem then, that the version of history propagated by the CPSU at trial is the one that survives today.

In the conclusion to this thesis I look to the future of Russian democracy. Having made the case that the transformation of Russian polity did not take place notwithstanding the opportunities provided through political justice, I rely on the Arendtian remedy to action, that of further action, in order to suggest another space/mechanism capable of facilitating a transition to democracy: memory. I argue that because the trial of the CPSU and the Politburo Commission did not address the roots of authoritarianism, they have combined with a kind of historical amnesia to hollow-out the rule of law in Russia. Yet despite the weakening of democratic principles over the last decade, I contend that the opportunity for transformation remains present. Moreover, I argue that by targeting remembrance and commemoration efforts, the Russian government has invested enough political capital within these issues to make them the next viable path toward the fulfillment of political justice.

\footnotetext{
${ }^{74}$ Smith, supra note 18 at 45 .
} 


\section{CONCLUSION}

\section{(RE)Living The Past}

"... is it true that the people will be unable to survive crossing the desert of organized forgetting?",

Within transitional justice literature there is little agreement about the way a transition to democracy should take place. Nevertheless, most scholars advocate for some form of political, juridical, or moral condemnation of the undemocratic regime. Addressing a criminal legacy through prosecutions, lustrations, compensation, commemoration of victims, or public acknowledgement, enables governments and people to judge the past and build new civic-democratic societies. In this thesis, I have argued that a break with the past, made possible through the apprehension of natality contained within mechanisms of political justice, was both necessary and unrealized in Russia. The repressive machinery and institutions of the Soviet regime, along with its practices, were neither dismantled nor discredited during the time of transition. The Politburo Commission and the trial of the CPSU, two cases of attempted political justice, held potential for a real reckoning with the past. However, in the end, neither judged the Soviet regime sufficiently. This lack of critical reflection allowed for continuity with the past to persist and subvert the establishment of democracy. Accordingly, I conclude this thesis by first illustrating the nature of this continuity, embodied most directly in the absence of the rule of law in Russia, and then looking forward in order to propose the next avenue for political justice: memory. I contend that public memory and spaces of commemoration offer the possibility of disputing the authority of a hegemonic historical narrative and delegitimizing certain state practices, thereby making them ineligible for resurrection by a government claiming to have embraced

\footnotetext{
${ }^{1}$ Milan Kundera. The Book of Laughter and Forgetting. (New York: Perennial Classics, 1976) at 218.
} 
democracy. By examining the potential for democratization in Russia, I demonstrate that the value of the political justice framework, its perpetual capacity for facilitating political transformation, is not limited to traditionally understood 'transitional periods.'

\section{Rule of Law}

Russia's political transition from dictatorship to democracy was incomplete. Yet the case for incompleteness cannot be made simply by pointing out the inherent contradiction in applying the labels of 'sovereign' or 'managed' to democracy. Nor is the country's limited history of non-competitive presidential elections enough to illustrate a significant deficiency. A closer and more substantive analysis of the way power is administered by the state or, more precisely, how closely the state obeys boundaries drawn around the legitimate use of power, is needed. Democracy, after all, is "a system of governance in which the rulers are held accountable for their actions in the public realm by citizens, acting indirectly through the competition and cooperation of their elected representatives." ${ }^{2}$ The mechanisms that assure accountability and facilitate democracy are embodied within the rule of law, a "notion that political authority should be subject to legal/constitutional limitations and that individuals are entitled to certain fundamental rights." ${ }^{3}$ Thus, democracy and the rule of law form essential parts of each other.

The rule of law, or pravavoe gosudarstvo, does not have deep roots in Russian jurisprudence. It was not part of the legal system created under the Tsars, nor was it included within the principles of Soviet legality. As such, both before and after the Bolshevik Revolution, the law was seen (and used) as an instrument of political power and the idea that

\footnotetext{
${ }^{2}$ Phillipe C. Schmitter and Terry Lynn Karl. "What Democracy is...and is Not" (1991) Journal of Democracy, Vol. 2 (3) at 76.

${ }^{3}$ Michael Newcity. "Russian Legal Tradition and the Rule of Law" in Jeffrey D. Sachs and Katharina Pistor eds., The Rule of Law and Economic Reform in Russia. (Boulder:WestviewPress, 1997) at 52.
} 
"any government must be subordinate to the law...was neglected." ${ }^{4}$ In order to facilitate the growth of democracy and a market economy after the collapse of the Soviet Union, Russia's legal institutions were "reshaped in a rapid and necessarily topdown fashion." The approach was two-pronged: first, market incentives in the form of private property and private wealth accumulation were introduced in the hope that they would inspire compliance with new legal regulations; second, 'democratic infrastructure,' like the 1991 Constitution guaranteeing civil and political rights, was transplanted into the Russian system in order to ensure government accountability. Both approaches, to some extent, embodied a version (or vision) of the rule of law. As John Borneman points out, the rule of law "has always meant different things to different people. Some analysts see it as a set of procedures to protect individuals from arbitrary rule, while others view it as the progressive march of reason and rationality. The former tend to focus on human rights and political liberties, the latter on contract and property rights." In this thesis I have examined the rule of law as it functions within the public sphere, regulating the relationship between the state and the citizen. This is a position more closely aligned with Borneman's first categorization. There is, however, a variety of scholarly literature that addresses the problems with instituting the rule of law within the private sphere. This work, stemming from the second conception of the rule of law articulated by Borneman and analysing the use of law in market transactions, is useful to my own arguments and reaches many of the same conclusions. As such, I review both the problems and solutions it addresses below.

\footnotetext{
${ }^{4}$ A. M. Yakovlev. "The Rule-of-Law Ideal and Russian Reality" in Stanislaw Frankowski and Paul B. Stephen III eds., Legal Reform in Post-Communist Europe. (The Netherlands: Martinis Hijhoff Publishers, 1995) at 15.

${ }^{5}$ Kathryn Hendley. "Legal Development in Post-Soviet Russia" (1997) Post-Soviet Affairs, Vol. 13 (3) at 2289.

${ }^{6}$ John Borneman. Settling Accounts: Violence, Justice, and Accountability in Postsocialist Europe. (Princeton, Princeton University Press, 1997) at viii.
} 
Since the initial planting of the rule of law in Russia, scholars like Kathryn Hendley and Alena V. Ledeneva have researched the increase, or absence thereof, in 'law-abiding' or 'rule-abiding' behaviour. It seems that while the 'Development Argument,' consisting of a top-down transplanting of 'Western' rules, was keenly adopted both by Russian politicians and their foreign advisors, it has largely failed to inspire the kind of confidence in the law needed to usher in a liberal democracy or free market economy. Hendley has described some of the reasons for the discrepancy between expectations and actual results. First, legal reform was carried out without input from the economic actors involved in the system and therefore most affected by the new rules. This "privatization by decree"7 was not an interactive process, nor was it sufficiently explained to those responsible for enacting and instituting the changes. In general, this approach did not significantly differ from the practices of previous governments which used the law as an instrument of state rather than a reflexive mechanism for regulating society. Second, despite the introduction of incentives like private property, reliance on the law, which would have, theoretically, improved efficiency by guaranteeing predictability, did not significantly increase in the business world. Instead, Russian 'enterprise managers,' as Hendley describes them, continued to rely on informal networks of connections in order to resolve disputes. While personal connections and patron-client relationships are difficult to maintain and navigate, they offer a dependable way to ensure enforcement of decisions, something currently lacking in the formal legal system. Although primarily concerned with private sphere relationships, these problems also touch on the issue of overall state legitimacy. In Russia today, neither the rules, nor the state which dictates them, carry legitimacy in the eyes of society.

\footnotetext{
${ }^{7}$ Hendley, supra note 5 at 236.
} 
By way of possible solution, Hendley argues that the focus should be shifted from the 'supply of law,' or rule creating, to the 'demand for law,' or rule enforcement. "Absent a credible threat of coercive action by the state if law is disobeyed, people tend to look elsewhere for assistance in enforcement." ${ }^{, 8}$ Therefore, ensuring the enforceability of legal judgments, for example by hiring more civil bailiffs, would prove the value of the legal system. Moreover, public attitudes toward the law need to be persuaded to change; the law must be seen as both useful and universally obeyed. I think that this second element is key, and underpins the problems with implementing the 'Development Argument' described above. "All-important...is the commitment on the part of the state to obey the rules it imposes on others. Although professing publically the ideals of the provovoe gosudarstvo, the Russian government habitually exempts itself and its officials from the law." ${ }^{.9}$ As such, in Russia, the law continues to be a "sword [ ] brandished by the state, rather than a shield protecting society. ${ }^{10}$ Whereas Hendley proposes that greater economic incentives and a commitment to general rule abiding by all parties will bolster the use and therefore usefulness of the rule of law, I argue that a more fundamental alteration in the application of political power is also needed. A firm recognition of the difference between the way an authoritarian government applied power and the way a democratic government exercises authority would endow Russian democracy with much needed substance.

It is clear that the early models of democratization in Russia have not resulted in the creation of Western-style democracy. A market economy and certain markers of democracy, like the right to vote and run for elected office, the right of expression and information, and

\footnotetext{
${ }^{8}$ Hendley, 'Legal Development', supra note 5 at 246.

9 Kathryn Hendley. "Rewriting the Rules of the Game in Russia: The Neglected Issue of the Demand for Law" (1999) East European Constitutional Review, Vol. 8 at 95.

${ }^{10}$ Hendley, 'Legal Development', supra note 5 at 237.
} 
the right to form organizations free from state interference, ${ }^{11}$ exist in Russia today but have not prevented the creation of a system of leadership with "a nominal head of state cohabitating with a supreme party leader and premier." ${ }^{\prime 2}$ Early attempts at transposing a democratic regime onto existing Russian institutions did not foster substantial change in either attitudes toward the political and legal system on the part of the public, or general commitment to democratic principles on the part of the state. More recently, a further 'hollowing-out' of democratic institutions, making them mere conduits of executive power, has been undertaken by the government. In addition to economic explanations like the one offered by Hendley, I propose that the failure of democracy to 'take root' in Russia has been possible in part because of the incomplete break with the Soviet past. Below I add to the discourse on the rule of law in Russia by making the argument that violations of those procedures and principles established and protected by the rule of law have not been problematized in part because the Soviet regime, which originally normalized these violations, was not sufficiently rejected or discredited. In order to illustrate this, I discuss the treason trial of Igor Sutyagin. Sutyagin's case is just one example of the way Soviet-style tactics and attitudes about the malleability of law are being resurrected to prosecute those who do not 'protect' their country in a way that is aligned with state interests.

\footnotetext{
${ }^{11}$ These are three of the seven 'procedural minimal conditions' listed by Robert Dahl in Dilemmas of Pluralist Democracy. (New Haven: Yale University Press, 1982) at 11.

${ }^{12}$ Vitali Silitski. "Tools of Autocracy" (2009) Journal of Democracy, Vol. 20 (2) at 44. Silitski argues the Kremlin's hold on power is accomplished through the 'manufacture of consent,' which consists of: propaganda aimed at discrediting opposition before they enter the political arena; formal changes to electoral rules designed to exclude the possibility of serious political opposition; providing a steady stream of material benefits financed by petrodollars and widening the zone of social autonomy.
} 
Sutyagin, a researcher working for the USA - Canada Institute at the Russian Academy of Sciences, was arrested by FSB officers on October $27^{\text {th }}, 1999 .{ }^{13}$ He was charged with treason and espionage for providing classified information on military policy and nuclear weapons to a British firm, Alternative Futures. ${ }^{14}$ Sutyagin admitted collecting the information in question as part of a freelance consultancy contract but claimed that all the information was available in the public domain. His first trial began in December of 2001 at the Kaluga Province Court, but was halted when the presiding judge, after reviewing the evidence, instructed the FSB to re-investigate. ${ }^{15}$ At the time, the Russian criminal code allowed for this kind of 'return for supplementary investigation' order as an alternative to acquittal, though it has since been eliminated because it violates a citizen's right to due process. ${ }^{16}$ After the re-investigation, hearings began again in November of 2003 and the case was transferred to the Moscow City Court. Despite the fact that the original charges had been dropped, Sutyagin was not released from prison in the meantime.

The Moscow hearings were closed to the public because the evidence against Sutyagin was deemed classified. After a few preliminary hearings, the original judge assigned to the case was removed without explanation. ${ }^{17}$ A new justice, Judge Marina Kamarova, was assigned to the case, immediately dismissing the jury and selecting a new

\footnotetext{
${ }^{13}$ Alexander Petrov. "Russia's 'Spy Mania': A Study of the Case of Igor Sutyagin" (October 2003) Human Rights Watch Briefing Paper. Available on-line: http://www.hrw.org/en/reports/2003/10/27/russia-s-spy-mania at 2.

${ }^{14}$ Vladimir Kovalev. "Russian Researcher Given 15 Years for Spying" (13 April 2004) Transitions Online, available on-line: http://www.tol.cz/look/TOL/article.tpl?IdLanguage $=1 \& I d P u b l i c a t i o n=4 \& N r I s s u e=59 \&$ NrSection $=1 \&$ NrArticle $=11904$

${ }^{15}$ Peter Solomon. "The Sutyagin case doesn't indict all Russian justice" (14 April 2004) The Globe and Mail, at A15.

${ }^{16}$ Ibid.

${ }^{17}$ Peter Baker. "Russian spy trial on hold" (26 December 2003) The Montreal Gazette, at A38.
} 
one. ${ }^{18}$ On April $5^{\text {th }}, 2004$ Sutyagin was convicted of high treason for providing information to a foreign organization. A week later, he was sentenced to fifteen years of hard labour. He is currently serving his sentence at the Arkhangelsk penal colony on the coast of the White Sea in the north of Russia. ${ }^{19}$

Apart from the fact that Sutyagin's conviction was arrived at only after three separate trial attempts, there were other ways in which this case violated principles of the rule of law. First, there are serious concerns about the jury charge delivered by the judge. During the trial, Judge Kamarova refused defence requests to have expert testimony on the definition of 'state secret' heard. This testimony went to the heart of the defence's argument that the information used by Sutyagin was available to anyone in the public domain. Instead, keeping a firm hold on the way the trial was conducted, the judge instructed the jury to only decide whether Sutyagin had worked with the information in question and whether he had been paid. ${ }^{20}$ Because Sutyagin disputed neither of these facts, and only challenged the state's assertion that the information was secret, he was found guilty.

The second problematic element in the trial also had to do with the jury. After the case was moved to Moscow, Sutyagin's defence team opted for a jury trial, presumably because jury trials had a 15 per cent acquittal rate as opposed to 0.8 per cent acquittal rate in cases heard by a judge. ${ }^{21}$ However, as mentioned above, a month after the first judge selected a jury, both were dismissed by the government. The newly appointed judge, who "had

\footnotetext{
${ }^{18}$ Michael Mainville. "The Big Chill: Paranoia alive, well in Russia" (18 April 2004) The Montreal Gazette, at D2.

${ }^{19}$ Charlotte Wilson. "Igor Sutyagin - Russian Physicist, Arms Control Expert and Political Prisoner" (17 January 2009) Worldview - Opinion, available on-line: http://www.worldviewopinion.com/blog/_archives/ 2009/1/17/4060812.html

${ }^{20}$ Mainville, supra note 18 .

${ }^{21}$ Solomon, supra note 15.
} 
already delivered convictions in two other politically sensitive cases,"22 selected new jurors. After the trial, it was revealed that at least one of the jurors, Grigorii Yakimiishen, was an intelligence officer with the FSB. ${ }^{23}$ Despite the myriad of problems with the case, the Supreme Court turned down Sutyagin's appeal in early $2007 .{ }^{24}$ Deputy Prosecutor General Vladimir Kolesnikov commented on Sutyagin's case to the Interfax news agency, saying: "It is a warning to others: Protect your country.

Although clearly not a 'fair' proceeding, this case cannot be properly described as a partisan or show trial. However, the element of risk, which, as discussed in chapter one, is preserved through procedural safeguards and "guarantees...political trials today remain a contest, rather than a unilateral reaffirmation of unassailable power positions, ${ }^{, 26}$ was so minimized by the state in this case as to be almost nonexistent. As a result, I suggest that Sutyagin's trial is a marker on the road to the instrumentalization of the judiciary by the executive which is being facilitated by the gradual loosening of procedural constraints. This trend has been made possible not only by the way the rule of law has been implemented in Russia, as discussed above, but also by a socio-political continuity with the Soviet past.

The unbroken, and recently strengthened, connection with the Soviet system has also influenced public opinion. General apathy toward the political process, itself made possible by an incomplete break with the authoritarian past, has allowed the government to disregard formally guaranteed rights without provoking public outrage. There is a "deepening

\footnotetext{
${ }^{22}$ Solomon, supra note 15 .

${ }^{23}$ Some reports claim that there was only one intelligence officer on the jury, other reports have cited as many as four FSB officers, see for example Julius Strauss. "Russia scientist jailed 15 years for spying" (8 April 2004) National Post, at A12.

${ }^{24}$ Solomon, supra note 15 .

${ }^{25}$ Kovalev, supra note 14 .

${ }^{26}$ Otto Kirchheimer. Political Justice: The Use of Legal Procedure for Political Ends. (Princeton: Princeton University Press, 1961) at 50.
} 
disillusion with the mechanisms of representative democracy...[and] many think government is less likely to treat them fairly and equally than it did in the Soviet period." ${ }^{27}$ And yet, this dissatisfaction should not suggest, as it has to some Western observers, that Russians are somehow inherently unable to appreciate or build a democracy. In a 2004 article entitled "Flight from Freedom: What Russians Think and Want" Richard Pipes, a professor of history at Harvard University and former Director of Eastern European and Soviet Affairs at the National Security Council, argued that Russians hold the judicial system in contempt as "both corrupt and subservient to the state" and that "democracy is widely viewed as a fraud. ${ }^{, 28} \mathrm{He}$ went on to suggest that "there is a good deal of evidence that the antidemocratic, antilibertarian actions of the current administration are not inflicted on the Russian people but are actually supported by them." ${ }^{29}$ The evidence Pipes relied on came from public surveys that asked respondents to pick between 'freedom' and 'order,' with 88 per cent of respondents choosing order. ${ }^{30}$ Pipes bemoaned the way Russians seemed incapable of understanding that the two concepts were not mutually exclusive and could act to re-enforce each other. Crucially, however, what Pipes overlooked in his analysis, apart from the fact that the poll he examined forced participants to choose between the options provided, was that experiencing democracy is an important part of appreciating it. An overnight commitment to democratic principles, whether through political, legal or economic changes, cannot be expected to actually signal a turn away from authoritarian government in anything but rhetoric. Enshrining rule of law principles in constitutions or other legislation is only a

\footnotetext{
${ }^{27}$ Stephen White "Political Disengagement in Post-communist Russia: a Qualitative Study" (2005) Europe Asia Studies, Vol. 57 (8) at 1121.

${ }^{28}$ Richard Pipes. "Flight from Freedom: What Russians Think and Want" (2004) Foreign Affairs, Vol. 83 (3) at 11-12.

${ }^{29}$ Ibid at 9.

${ }^{30}$ Ibid at 11 .
} 
first step in creating democracy. Belief in the value of those institutions is also needed. Part of the understanding this lack of belief and examining the future of Russian democracy depends on stepping back to examine why the rule of law has not been vested with value despite being formally adopted. I have already suggested the answer by looking at the legal and economic consequences of continuity with the past; I want to now move to the social consequences of a failed political break.

\section{"A past which is not overcome..."31}

In the introduction of this thesis I discussed some of the relics of the Soviet past which have been reclaimed in recent years by the Russian government: the national anthem, the public image of Stalin, and Lenin's continued presence in the Red Square. During perestroika, and immediately following the collapse of the Soviet Union, there was an avalanche of memory or, more precisely, countermemory. New histories of WWII appeared along with volumes of personal memoirs from GULAG survivors. It seemed that people revelled in the new found ability to examine the past freely, to debate it, to challenge it, to discredit it. To own history, personal and public, was a completely new experience for a people who had been forced to exist as mankurts ${ }^{32}$ - people without memory - for over seven decades. Slowly, however, the wave of memory shifted from acceptable, to fashionable, to kitsch, to taboo, before finally slipping into irrelevance. Revelations about just how bad the

\footnotetext{
${ }^{31}$ Anatoly M Khazanov and Stanley G. Payne "How to Deal with the Past?" (2008) Totalitarian Movements and Political Religions, Vol. 9 (2-3) at 415.

${ }^{32}$ A mankurt is a person who, after being tortured, looses the ability to remember and becomes a happy and willing slave, see Chinghiz Aitmatov. The Day Lasts Longer Than a Hundred Years.
} 
past had been overwhelmed people and, in the economic chaos of the 1990s, "history once again lost its mass appeal.",33

Almost a decade after the demise of popular history, the Soviet past began to be revived by the state. But how could symbols used as banners of an ideology propagated by a regime that killed millions be dusted off and used so casually by a government claiming to be democratic? Was this resurrection just one sign of deeper problems within the Russian state? Throughout the initial research and the writing of this thesis, I started to perceive that the reanimation of the Soviet past was just the most explicit expression of a return to authoritarianism which had never been purged from the foundations of the state. "[A]fter the collapse of the Soviet Union, it became clear that, in spite of great social transformation and the publication of revealing documents and onslaught of personal memoirs, short-lived public reflection on the experience of communism and particularly, state repression, failed to produce any institutional change." 34 The transition to democracy had been incomplete; the past was not sufficiently rejected. Although political justice had been attempted several times, it never fulfilled the dual elements of natality: judgement and rebirth. The Soviet past was always judged only in part; the regime was never condemned as a whole. And as a result, Russian democracy sprang from a false footing never achieving a true political rebirth. Nevertheless, just as the resurgence of Soviet history is part of a larger problem of un-reform, so too can it prove to be a crucial element of democratic development. This is because the past, like nostalgia for Svetlana Boym, is "a double-edged sword: it seems to be an emotional antidote to politics, and thus remains the best political tool.. ${ }^{35}$ Embracing the

\footnotetext{
${ }^{33}$ Nanci Adler. "The Future of the Soviet Past remains Unpredictable: The Resurrection of Stalinist Symbols Amidst the Exhumation of Mass Graves" (2005) Europe - Asia Studies, Vol. 57 (8) at 1094.

${ }^{34}$ Svetlana Boym. The Future of Nostalgia. (New York: Basic Books, 2001) at 58.

${ }^{35}$ Ibid.
} 
past's political utility is key and will make the struggle to remember the next site of political justice in Russia. The Russian government itself has chosen this space of struggle by repeatedly targeting sources of countermemory for persecution. By singling out commemoration efforts as somehow dangerous or opposed to government interests, the state had vested them with political capital. Last year, the Kremlin authorized a criminal investigation into the activities of Memorial, convening an Investigative Committee of the Russian General Prosecutor's Office. In December of 2008, police raided Memorial's Information Center and confiscated part of their archives. ${ }^{36}$ In May of 2009, President Medvedev announced the formation of a government commission for the protection of Russian history. ${ }^{37}$ This commission will act to counter any attempts to 'disparage' Russia's national reputation and will also formulate public policy responses for the president to consider. These developments have thrust memory back into the public spotlight and have highlighted certain 'rough spots' in the national historical narrative.

Other unintentional and unpredictable consequence of a past that has not been overcome also present opportunities for opening a space of debate and are less likely to fall under the direct control of the government. Skeletal remains of victims of political repression continue to be unearthed periodically in forests and urban centers like Moscow and St. Petersburg. These 'bodies of terror,' like the ones found during remodelling in the basement of the Russian Supreme Court, serve as tangible evidence of an uncomfortable and officially

\footnotetext{
${ }^{36}$ Orlando Figes. "The Raid on Memorial” (15 January 2009) The New York Review of Books, Vol. 56 (1) available on-line: http://www.nybooks.com/articles/22248?email

37 Andrew Osborn. "Medvedev Creates History Commission" (21 May 2009) The Wall Street Journal, available on-line: http://online.wsj.com/article/SB124277297306236553.html
} 
unacknowledged legacy. And in a country which has been described as 'built on bones,38 these discoveries will continue to occur. As such, each new uncovered grave will need to be addressed and incorporated into the national narrative, again providing a chance to challenge the way the past is remembered. Even days on the calendar form part of the terrain of struggle over memory. The $7^{\text {th }}$ of November has been a national holiday in Russia since the Bolshevik Revolution and continues to be one today. During the Soviet period, this was the Day of the Revolution marking the October Revolution. After the collapse, the day was rebranded by Yeltsin as the Day of Agreement and Reconciliation in 1997. November $7^{\text {th }}$ is still a national holiday, but its significance remains undefined for the Russian public.

Political justice, by facilitating natality, can be consciousness-transforming and valuable because it opens the 'space' of politics in which ideas and identities can be debated. Political justice can and does happen in the court room, though it is not limited to it. In Russia, the nearest fulfillment of natality through political justice took the form of a truth commission, a constitutional challenge and a three day anti-coup popular demonstration. And as the country moves forward, criminal trials will continue to carry the possibility of political justice, though, as in Sutyagin's case, this possibility will be limited. Nevertheless, a broader understanding of political justice allows for the focus to be turned away from state institutions.

Memory and political justice have several things in common. Both are on-going and not limited to, or by, an outcome. The opportunity for revision was what Kirchheimer considered the most rewarding aspect of, and the reproach against, political justice. Similarly, public memory, understood as "the cultural space and processes through which a

\footnotetext{
${ }^{38}$ Oleg Golovanov, coordinator of the grave discovery project for Memorial, quoted by Irina Paperno "Exhuming the Bodies of Soviet Terror" (2001) Representations, Vol. 75 at 89.
} 
society understands, interprets and negotiates myths about its past" ${ }^{\mathrm{3} 9}$ is also a process of revision. Both also provide the opportunity to transform, "create[ ] and respond[ ] to power relations and identities. ${ }^{, 40}$ Thus, memory and political justice hold potential for confronting the past and creating anew. I suggest that by challenging the resurrection of Soviet symbols, thereby disputing the perception of legitimacy of the Soviet regime, memory can provide exactly the judgement needed for a political rebirth. Discrediting Soviet tactics, machinery, and modes of governance will not strip the current government of power, but it will force a change in the way that power is applied, making violations of the rule of law less acceptable.

It is unquestionably true that examining political justice within the fields of commemoration and public memory is difficult. They are undefined and unbound spaces, less tangible and perhaps even more risky than other avenues of political justice. But, by taking up the cause of preserving history, the Russian government has politicized memory and invested parts of its authority within it. The possible rewards of challenging the state in this way are many and have already been discussed. At the very least, competing historical narratives can taint the resurgence of nostalgia for the glorious Soviet past. For this reason alone, memory and commemoration should become central issues for those seeking to enforce the rule of law in Russia.

Ultimately, however, political justice is always an attempt. And just as commemoration and memory politics present advantages as a possible space of political justice, they also carry certain hazards. Reclaiming memory must be, and inherently is, a deeply personal experience. In Russia, contesting memory will be morally and spiritually uncomfortable and, as such, a difficult process for the public to undertake. This will be a

\footnotetext{
${ }^{39}$ Benjamin Forest, Juliet Johnson and Karen Till. "Post-totalitarian national identity: Public memory in Germany and Russia" (2004) Social \& Cultural Geography, Vol. 5 (3) at 358.

${ }^{40}$ Ibid at 363 .
} 
battle not between remembering and forgetting, but between memory and nostalgia, commemoration and kitsch. It will require acknowledging a personal history of culpability, whether through direct participation, implicit compliance, or tacit acceptance. Revelations about the past will mean "not only the truth about Stalin, but the truth about ourselves and about our illusions. ${ }^{, 41}$ It will entail the dismantling of the images of a great and vanished past and the belief in a country ruled by "monumental (if oppressive) leaders." ${ }^{42}$ This will be an on-going struggle against the tide of comfortable and comforting amnesia for Russians who have "become tired of suffering and those who suffered." Despite all this, the effort to insulate the past from debate has to be opposed and an attempt at political justice must be made. Without this attempt, the Soviet system will continue to outlast the Soviet state.

${ }^{41}$ Stephen F. Cohen. "The Stalin Question since Stalin" in Stephen F. Cohen eds., An End to Silence: Uncensored Opinion in the Soviet Union: From Roy Medvedev's Underground Magazine Political Diary (New York and London: W. W. Norton and Company, 1982) at 29.

${ }^{42}$ Nina Khrushcheva. "'Rehabilitating' Stalin" (2005) Reflections: World Policy Journal, Vol. 22 (2) at 67.

${ }^{43}$ Anatoly M. Khazanov. "Whom to Moum and Whom to Forget? (Re)constructing Collective Memory in Contemporary Russia" (2008) Totalitarian Movements and Political Religions, Vol. 9 (2-3) at 307. 


\section{BIBLIOGRAPHY}

"In the Case of the Verification of the Constitutionality of Edicts of the President of the

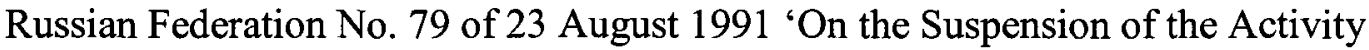
of the Communist Party of the RSFSR,' No. 90 of 25 August 1991 'On the Property of the CPSU and the Communist Party of the RSFSR,' as well as of the Verification of the Constitutionality of the CPSU and the CP RSFSR." (1992) Constitutional Court of the Russian Federation. Statutes and Decisions: The Laws of the USSR and Its Successor States, Vol. 30 (4): 8 - 43.

Adler, Nanci. "The Future of the Soviet Past Remains Unpredictable: The Resurrection of Stalinist Symbols Amidst the Exhumation of Mass Graves" (2005) Europe-Asia Studies, Vol. 57 (8): $1093-1119$.

- - Beyond the Soviet System: The Gulag Survivor. (New Brunswick and London: Transaction Publishers, 2002).

Ahdieh, Robert B. Russia's Constitutional Revolution: Legal Consciousness and the Transition to Democracy 1985 - 1996. (Pennsylvania: The Pennsylvania State University Press, 1997.)

Akhmatova, Anna. Pamiati Anny Akhmatovio. (Paris: YMCA Press, 1975).

Alexopoulos, Golfo. "Victim Talk: Defense Testimony and Denunciation under Stalin." (1999) Law and Social Inquiry, Vol. 24 (3): 637 - 654.

- - "Soviet Citizenship, More or Less: Rights, Emotions, and States of Civil Belonging." (2006) Kritika: Explorations in Russian and Eurasian History. Vol. 7 (3): $487-528$.

Afanas'ev, Iurii. "Power as Ends and Means: Russia's Two Possible Paths in Past and Present." (2005) Russian Politics and Law, Vol. 43 (6): 6 - 21.

Applebaum, Anne. GULAG: A History. (New York, London, Toronto, Sydney \& Auckland: Doubleday, 2003).

Arendt, Hannah. "Understanding and Politics" (1953) Partisan Review, Vol. 20 (4): 377 -392 .

_- "Social Science Techniques and the Study of Concentration Camps" (1950) Jewish Social Studies, Vol. 12 (1): 49 - 64.

- - On Violence. (San Diego, New York and London: Harcourt Brace and Company, 1970). 
- The Human Condition. $2^{\text {nd }}$ Edition. (Chicago and London: University of Chicago Press, 1998).

- - The Promise of Politics. (New York: Schoken Books, 2005).

- - Between Past and Future: Eight Exercises in Political Thought. (New York: Penguin Books, 2006).

- Eichmann in Jerusalem: A Report on the Banality of Evil. (New York: Penguin Books, 2006).

Baker, Peter. "Russian spy trial on hold" (26 December 2003) The Montreal Gazette, A38.

Barahona de Brita, Alexandra, Carmen Gonzalez-Enriquez \& Paloma Aguilar eds., The Politics of Memory: Transitional Justice in Democratizing Societies. (Oxford: Oxford University Press, 2001).

Barry, Donald D. and Yuri Feofanov. Politics and Justice in Russia: Major Trials of the Post-Stalin Era. (New York and London: M. E. Sharpe, 1996).

Bayev, Aleksei A. "I Don't Admit the Charge" (2004) Molecular Biology, Vol. 38 (2): $352-361$.

Becker, Theodore L. Political Trials. (Indianapolis and New York: The Bobbs-Merrill Company, 1971).

Berdahl, Daphne. "(N)ostalgia for the Present: Memory, Longing and East German Things." (1999) Ethnos: Journal of Anthropology, Vol. 64 (2): $192-211$.

Berdahl, Daphne, Matti Bunzl, and Martha Lampland eds., Altering States: Ethnographies of Transition in Eastern Europe and the Former Soviet Union. (Ann Arbor: The University of Michigan Press, 2003).

Bickford, Louis. "Unofficial Truth Projects" (2007) Human Rights Quarterly, Vol. 29: $994-1035$.

Bilsky, Leora. Transformative Justice: Israeli Identity on Trial. (Ann Arbor: The University of Michigan Press, 2007).

Birmingham, Peg. "The An-Archic Event of Natality and the 'Right to Have Rights" " (2007) Social Research, Vol. 74 (3): $763-776$.

Bonnell, Victoria E., Ann Cooper \& Gregry Freidin eds., Russia at the Barricades: Eyewitness Accounts of the August 1991 Coup. (Armonk and London: M. E. Sharpe, 1994). 
Bonnell, Victoria and Gregory Freidin. "Televerot: The Role of Television Coverage in Russia's August 1991 Coup" in Nancy Condee eds., Soviet Hieroglyphics: Visual Culture in Late Twentieth-Century Russia. (Bloomington and Indianapolis: Indiana University Press, 1995).

Bowen-Moore, Patricia. Hannah Arendt's Philosophy of Natality. (Houndmills, Basingstoke, Hampshire and London: The MacMillan Press Ltd, 1989).

Borneman, John. Settling Accounts: Violence, Justice, and Accountability in Postsocialist Europe (Princeton: Princeton University Press, 1997).

Boym, Svetlana. The Future of Nostalgia. (New York: Basic Books, 2001).

Brandys, Kazimierz. A Warsaw Diary: 1978 - 1981. Richard Lourie trans., (New York: Random House, 1983).

Breen, Keith. "Violence and Power: A Critique of Hannah Arendt on the 'Political"" (2007) Philosophy and Social Criticism, Vol. 33 (3): 343 - 372.

Brzezinski, Zbigniew. The Passing of an Illusion: The Idea of Communism in the Twentieth Century. (Chicago: University of Chicago Press, 1999).

Carothers, Thomas. "The End of the Transition Paradigm" (2002) Journal of Democracy, Vol. 13 (1): 5-21.

Christenson, Ron eds., Political Trials in History: From Antiquity to the Present. (New Brunswick and London: Transaction Publishers, 1991).

- - Political Trials: Gordian Knots in the Law. (New Brunswick and London: Transaction Publishers, 1999).

_- "A Political Theory of Political Trials" (1983) Journal of Criminal Law and Criminology, Vol. 74 (2): 547 - 577.

Cohen, Stephen F. eds., An End to Silence: Uncensored Opinion in the Soviet Union from Roy Medvedev's Underground Magazine Political Diary George Saunders trans., (New York and London: W. W. Norton \& Company, 1982).

Conquest, Robert. The Harvest of Sorrow: Soviet Collectivization and the Terror Famine. (London: Pimlico, 2002).

- - The Great Terror: A Reassessment. (Oxford: Oxford University Press, 2008).

Crocker, David A. "Reckoning with Past Wrongs: A Normative Framework" (1999) Ethics and International Affairs, Vol. 13 (1): 43-64. 
Dahl, Robert. Dilemmas of Pluralist Democracy. (New Haven: Yale University Press, 1982.)

Daly, Erin. "Truth Scepticism: An Inquiry into the Value of Truth in Times of Transition" (2008) International Journal of Transitional Justice, Vol. 2 (1): 23 41.

Daniels, Robert V. The Rise and Fall of Communist Russia. (New Haven \& London: Yale University Press, 2007).

Davies, R. W. Soviet History in the Gorbachev Revolution. (London: The MacMillian Press, 1989).

Dolan, Frederick M. 'An Ambiguous Citation in Hannah Arendt's The Human Condition" (2004) Journal of Politics, Vol. 66 (2): 606-610.

Dunlop, John B. The Rise of Russia and the Fall of the Soviet Union. (Princeton: Princeton University Press, 1993).

- - "The August Coup and Its Impact on Soviet Politics" (2003) Journal of Cold War Studies, Vol. 5 (1): $94-127$.

Easter, Gerald M. "Preference for Presidentialism: Postcommunist Regime Change in Russia and the NIS" (1997) World Politics, Vol. 49 (2): $184-211$.

Erlanger, Steven. "Russian Court Weighs Communist Party's Legality" (8 July 1992) The New York Times, A8.

Figes, Orlando. "The Raid on Memorial" (15 January 2009) The New York Review of Books, Vol. 56 (1) Available on-line: http://www.nybooks.com/articles/22248?email

Fitzgerald, Tara. "Accused spy's trial a 'warning' to researchers: Trial resumes form man hired by Carleton" (27 February 2001) The Ottawa Citizen, A5.

Forest, Benjamin, Juliet Johnsin and Karen Till. "Post-Totalitarian National Identity: Public Memory in Germany and Russia." (2004) Social \& Cultural Geography, Vol. 5(3): $357-380$.

Frankowski, Stanislaw and Paul B. Stephen III eds., Legal Reform in Post-Communist Europe: The View from Within. (The Netherlands: Martinus Nijhoff Publishers, 1995).

Franks, C.E.S. eds., Dissent and the State. (Toronto: Oxford University Press, 1989). 
Gibson, James L. "Mass Opposition to the Soviet Putsch of August 1991: Collective Action, Rational Choice, and Democratic Values in the Former Soviet Union." (1997) American Political Science Review, Vol. 91 (3): 671 - 684.

Grodsky, Brian. "Producing Truth: The Politics of Investigating Past Human Rights Violations in Post-Communist States." (2007) World Affairs, Vol. 169 (3): 125 133.

- - "Justice Without Transition: Truth Commissions in the Context of Repressive Rule." (2008) Human Rights Review, Vol. 9: 281 - 297.

Grossman, Joel B. "Political Justice in the Democratic State." (1976) Polity, Vol. 8 (3): $358-388$.

Gvosdev, Nikolas K. eds., The Strange Death of Soviet Communism: A Postscript. (New Brunswick and London: Transaction Publishers, 2008).

Gudkov, Lev. "Russia - A Society in Transition?" (2001) Telos, 120: 9-30.

Halliday, Frank. Revolutions and World Politics: The Rise and Fall of the Sixth Great Power. (Durham: Duke University Press, 2001).

Hendley, Kathryn. "Suing the State in Russia" (2002) Post-Soviet Affairs, Vol. 18 (2): $122-147$.

- - "Legal Development in Post-Soviet Russia" (1997) Post-Soviet Affairs, Vol. 13 (3): $228-251$.

_- "Rewriting the Rules of the Game in Russia: The Neglected Issue of the Demand for Law" (1999) East European Constitutional Review, Vol. 8: 89 - 95.

Hochschild, Adam. The Unquiet Ghost: Russians Remember Stalin. (New York: Viking, 1994).

Hodos, George H. Show Trial: Stalinist Purges in Eastern Europe 1948 - 1954. (New York: Præger, 1987).

$\mathrm{H} \square$ ffe, Otfried. Political Justice: Foundations for a Critical Philosophy of Law and the State. Jeffrey C. Cohen trans., (Cambridge: Polity Press, 1995).

Humphrey, C. "Mythmaking, Narratives and the Dispossessed in Russia." (1996) Cambridge Anthropology, Vol. 19 (2): $70-92$.

Huntington, Samuel P. The Third Wave: Democratization in the Late Twentieth Century. (Norman: University of Oklahoma Press, 1991). 
Igrunov, Vyacheslav. "Public Movements: From Protest to Political Self-Consciousness" in After Perestroika: Democracy in the Soviet Union. Brad Roberts and Nina Belyaeva eds., (Washington, D.C.: CSIS, 1991).

Kasparov, Garry. "It's No Mystery” (2009) Journal of Democracy, Vol. 20 (2): 39 - 41.

Kelly, Donald R. eds., After Communism: Perspectives on Democracy. (Fayetteville: The University of Arkansas Press, 2003).

Kharkhordin, Oleg. "Nation, Nature and Natality: New Dimensions of Political Action." (2001) European Journal of Social Theory, Vol. 4 (4): 459 - 478.

Khazanov, Anatoly M. "Whom to Mourn and Whom to Forget? (Re)constructing Collective Memory in Contemporary Russia." (2008) Totalitarian Movements and Political Religions, Vol. 9 (2-3): 293 - 310.

Khazanov, Anatoly M. and Stanley G. Payne. "How to Deal with the Past?" (2008) Totalitarian Movements and Political Religions, Vol. 9 (2-3): 411 - 431.

Khrushcheva, Nina. “"Rehabilitating' Stalin" (2005) Reflections: World Policy Journal, Vol. 22 (2): $67-73$.

Kirchheimer, Otto. Political Justice: The Use and Legal Procedure for Political Ends. (Princeton: Princeton University Press, 1961).

__ "Politics and Justice" (1955) Social Research, Vol. 22 (1): 377 - 398.

Kluegel, James R. and David S. Mason. "Fairness Matters: Social Justice and Political Legitimacy in Post-Communist Europe." (2004) Europe-Asia Studies, Vol. 56 (6): $813-834$.

Knight, Amy. "The KGB, Perestroika, and the Collapse of the Soviet Union" (2003) Journal of Cold War Studies, Vol. 5 (1): $67-93$.

_- "Don't be fooled by Putin" (15 June 2001) The Globe and Mail, A13.

Koestler, Arthur. Darkness at Noon. Daphne Hardy trans., (New York, London, Toronto and Sydney: Scriber, 1968).

Kovalev, Vladimir. "Russian Researcher Given 15 Years for Spying" (13 April 2004) Transitions Online, available on-line: http://www.tol.cz/look/TOL/article.tpl?Id Language $=1 \&$ IdPublication $=4 \&$ NrIssue $=59 \& \mathrm{NrSection}=1 \& \mathrm{NrArticle}=11904$

Kritz, Neil J. eds., Transitional Justice: How Emerging Democracies Reckon with Former Regimes, Volume II: Country Studies. (Washington, D.C.: United States Institute of Peace Press, 1995). 
Kundera, Milan. The Unbearable Lightness of Being Michael Heim trans., (New York: HarperCollins, New Olive Edition, 2008).

- - The Book of Laughter and Forgetting. Aaron Asher trans., (New York: HarperCollins, 1999).

Labin, Suzanne. Stalin's Russia. (London: Gollancz, 1949).

Latsis, Otto. Tschatel'no slpanirovannoe samoubiistvo. (Moscow: Moscow School of Political Science, 2001).

Ledeneva, Alena V. How Russia Really Works: The Informal Practices that Shaped PostSoviet Politics and Business. (Ithaca and London: Cornell University Press, 2006).

Lefort, Claude. "Thinking with and against Hannah Arendt" (2002) Social Research, Vol. $69(2): 447-459$.

Levi, Primo. The Drowned and the Saved. (New York: Summit Books, 1988).

Mainville, Michael. "The Big Chill: Paranoia alive, well in Russia" (18 April 2004) The Montreal Gazette, D2.

Malia, Martin. The Soviet Tragedy: A History of Socialism in Russia: $1917-1991$. (New York: The Free Press, 1994).

March, Luke. The Communist Party in post-Soviet Russia (Manchester and New York: Manchester University Press, 2002).

Markovitz, I. "Selective Memory: How the Law Affects What We Remember and What We Forget About the Past - The Case of East Germany." (2001) Law and Society Review, Vol. 35: 513 - 563.

Martin, Alison. "Report on Natality in Arendt, Cavarero and Irigaray." (2002) Paragraph: The Journal of the Modern Critical Theory Group. Vol. 25: 32 - 53.

Marsh, Frank and Charles Abel. In Defense of Political Trials. (Westport: Greenwood Press, 1994.)

Matlock, Jack Jr., Autopsy on an Empire: The American Ambassador's Account of the Collapse of the Soviet Union. (New York: Random House, 1995.)

McAdams, A. James eds., Transitional Justice and the Rule of Law in New Democracies. (Notre Dame and London: University of Notre Dame Press, 1997.)

McNaught, Kenneth. "Political Trials and the Canadian Political Tradition" (1974) University of Toronto Law Journal, Vol. 24: 149 - 169. 
Merridale, Catherine. Night of Stone: Death and Memory in Twentieth-Century Russia. (New York: Viking, 2000.)

Moore, David Chioni. "Is the Post- in Postcolonial the Post- in Post-Soviet? Toward a Global Critique" (2001) PMLA, Vol. 116 (1): 111 - 128.

Moran, John P. "The Communist Torturers of Eastern Europe: Prosecute and Punish or Forgive and Forget?" (1994) Communist and Post-Communist Studies, Vol. 27 (1): 95-109.

Moran, John P. and Eva Janiskova. "Justice or Politics? Criminal, Civil and Political Adjudication in the Newly Independent Baltic States." (2006) Journal of Communist Studies and Transitional Politics, Vol. 22 (4): 485 - 506.

Moskal'kova, Tat'iana N. "Rehabilitation of the Innocent in the Russian Federation" (1992) Review of Central and East European Law, Vol. 18 (5): 475 - 484.

Neidhart, Christopher. Russia's Carnival: The Smells, Sights, and Sounds of Transition. (Lanham, Boulder, New York and Oxford, Rowman \& Littlefield Publishers, Inc., 2003.)

Nora, Pierre. "Between Memory and History: Les Lieux de Mémoire" (1989) Representations, Vol. 26: 7-24.

Paperno, Irina. "Exhuming the Bodies of Soviet Terror." (2001) Representations, Vol. 75: $89-118$.

Parfitt, Tom. "Medieval Warrior overcomes Stalin in poll to name Greatest Russian" (29 December 2008) The Guardian, available on-line: http://www.guardian.co.uk/world/2008/dec/29/stalin-name-of-russia.

Pearson, Raymond. The Rise and Fall of the Soviet Empire. (New York: St. Martin's Press, 1998).

Petrov, Alexander. "Russia's 'Spy Mania': A Study of the Case of Igor Sutiagin" (October 2003) Human Rights Watch Briefing Paper. Available On-line: http://www.hrw.org/en/ reports/2003/10/27/russia-s-spy-mania.

Pipes, Richard. "Flight from Freedom: What Russians Think and Want" (2004) Foreign Affairs, Vol. 83 (3): $9-15$.

Posner, Eric A. and Adrian Vermeule. "Transitional Justice as Ordinary Justice" (2004) Harvard Law Review, Vol. 117 (3): 761-825.

Prozonov, Sergei. "Russian postcommunism and the end of history" (2008) Studies in Eastern European Thought, Vol. 60: 207 - 230. 
Remnick, David. "Report from Moscow: The Trial of the Old Regime." (30 November 1992) The New Yorker, 104-121.

- - Lenin's Tomb: The Last Days of the Soviet Empire. (New York: Random House, 1993.)

Rogers, Douglas. "Historical Anthropology Meets Soviet History" (2006) Kritika: Explorations in Russian and Eurasian History, Vol. 7 (3): 633 - 649.

Rywkin, Michael. "Putin's Russia: Neither Friend nor Foe." (2007) The American Journal of Foreign Policy Interests, Vol. 29 (1): 37 - 44.

Sachs, Jeffrey D. and Katharina Pistor eds., The Rule of Law and Economic Reform in Russia. (Boulder, Colorado: Westview Press, 1997).

Schell, Jonathan. "A Politics of Natality" (2002) Social Research, Vol. 69 (2): 461 - 471.

Schmitter, Phillipe C. and Terry Lynn Karl. "What Democracy is...and is Not" (1991) Journal of Democracy, Vol. 2 (3): 75 - 88.

Shapiro, Jane P. "Rehabilitation Policy under the Post-Khrushchev Leadership" (1969) Soviet Studies, Vol. 20 (4): $490-489$.

- Rehabilitation Policy and Political Conflict in the Soviet Union, 1953 - 1964. (1967) Unpublished PhD Dissertation, Faculty of Political Science, Columbia University.

Sharlet, Robert. Soviet Constitutional Crisis: From De-Stalinization to Disintegration. (Armonk and London: M. E. Sharpe, 1992).

Sheehy, Gail. The Man who Changed the World. (New York: Perennial Library, 1990).

Sheinis, Viktor. "August 1991: A Pyrrhic Victory" (2008) Russian Social Science Review, Vol. 49 (1): 4-23.

_ _ "The Russian Constitutional Court: The First Term" (1993) Post-Soviet Affairs, Vol. 9 (1): 1 - 39 .

Shklar, Judith. Legalism. (Cambridge: Harvard University Press, 1964.)

- After Utopia: The Decline of Political Faith. (Princeton: Princeton University Press, 1969.)

Silitski, Vitali. "Tools of Autocracy" (2009) Journal of Democracy, Vol. 20 (2): 42 - 46. 
Smith, Bruce L. R. and Gennady M. Danilenko eds., Law and Democracy in the New Russia. (Washington D. C.: The Brookings Institution, 1993.)

Smith, Kathleen E. Mythmaking in the New Russia: Politics and Memory during the Yeltsin Era. (Ithaca and London: Cornell University Press, 2002).

- - Remembering Stalin's Victims: Popular Memory and the End of the USSR. (Ithaca and London: Cornell University Press, 1996).

Smith, Michael G. "Stalin's Martyrs: The Tragic Romance of the Russian Revolution" (2003) Totalitarian Movements and Political Religions, Vol. 4 (1): 95 - 126.

Solomon, Peter. "The Sutyagin case doesn't indict all Russian justice" (14 April 2004) The Globe and Mail, A15.

Sriram, Chandra Lekha. Confronting Past Human Rights Violations: Justice vs Peace in Times of Transition. (London and New York: Frank Cass, 2004).

Steele, J. Eternal Russia: Yeltsin, Gorbachev, and the Mirage of Democracy. (Cambridge: Harvard University Press, 1994.)

Strauss, Julius. "Russian scientist jailed 15 years for spying" (8 April 2004) National Post, A12.

Suny, Ronald G. eds., The Structure of Soviet History: Essays and Documents. (New York and Oxford: Oxford University Press, 2003.)

- - "Revision and Retreat in the Historiography of 1917: Social History and Its Critics" (1994) The Russia Review, Vol. 53 (2): 165- 182.

Szmagalska-Follis, K. "Repossession: Notes on Restoration and Redemption in Ukraine's Western Borderland" (2008) Cultural Anthropology, Vol. 23 (2): 239 - 360.

Teitel, Ruti G. Transitional Justice. (New York: Oxford University Press, 2000).

Thompson, John M. Russia and the Soviet Union: An Historical Introduction from the Kievan State to the Present. $5^{\text {th }}$ Edition. (Colorado: Westview Press, 2004).

Tucker, Eric. "That Indefinite Area of Toleration: Criminal Conspiracy and Trade Unions in Ontario 1937 - 1977." (1991) Labour / Le Travail, Vol. 27: 15 - 54.

Verdery, Katherine. The Political Lives of Dead Bodies: Reburial and Postsocialist Change. (New York: Columbia Press, 1999.) 
Van Goudoever, Albert P. The Limits of Destalinization in the Soviet Union: Political Rehabilitation in the Soviet Union Since Stalin. Frans Hijkoop trans., (New York: St. Martin's Press, 1986).

Wertsch, James V. "Revising Russian History" (1999) Written Communications, Vol. 13 (3): $267-295$.

Weigle, Marccia A. "Political Participation and Party Formation in Russia, 1985 - 1992: Institutionalizing Democracy?" (1994) The Russia Review, Vol. 53 (2): 240 - 270.

White, Stephen. "Political Disengagement in Post-Communist Russia: a Qualitative Study” (2005) Europe-Asia Studies, Vol. 57 (8): 1121 - 1142.

Wilke, Christiane. "War v Justice: Terrorism Cases, Enemy Combatants, and Political Justice in U.S. Courts" (2005) Politics and Society, Vol. 33 (4): 637 - 669.

- _ "Recognizing Victimhood: Politics and Narratives of Rehabilitation in Germany" (2007) Journal of Human Rights, Vol. 6 (4): 479 - 496.

Wolfe, Bertram D. Khrushchev and Stalin's Ghost: Text, Background and Meaning of Khrushchev's Secret Report to the Twentieth Congress on the Night of February 24-25, 1956. (New York: Frederick A. Paeger, 1957).

Wright, Barry and Murray Greenwood eds., Canadian State Trials: Law, Politics, Security Measures 1608 - 1837. (Toronto: University of Toronto Press, 1996).

- - Canadian State Trials: Rebellion and Invasion in the Canadas 1837-1839. (Toronto: University of Toronto Press, 2002).

Yablokova, Oksana. "Scientist or Spy?" (29 November 2004) Transitions Online. Available on-line: http://www.tol.cz/look/TOL/article.tpl?IdLanguage=1\&Id Publication $=4 \& \mathrm{Nr}$ Issue $=92 \& \mathrm{NrSection}=1 \& \mathrm{Nr}$ Article $=13119$

Yakovlev, Alexandr N. eds., Reabilitatsia: Politicheskie protsessy 30-50kh godov. (Moscow: Politizdat, 1991.)

- 1 A Century of Violence in Soviet Russia. (New Haven and London: Yale University Press, 2002).

Yevtushenko, Yevgeny. A Precocious Autobiography. Andrew R. MacAndrew trans., (London: Collins and Harvill Press, 1963). 